\title{
MUSIC SEMIOLOGY: \\ CATEGORIES AND METHODS
}

Collective monograph

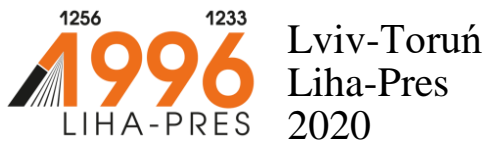




\section{Reviewers:}

Prof. nadzw., dr hab. Stanistaw Kunikowski, Rektor of Cuiavian University in Wloclawek (Republic of Poland);

Prof. $d r$ hab. Kazimierz Pierzchala, Katolicki Uniwersytet Lubelski/Catholic University of Lublin (Republic of Poland);

Prof. dr hab. Stanistaw Juszczyk, Uniwersytet Ślaski / University of Silesia (Republic of Poland).

Music semiology: categories and methods : collective monograph / A. I. Samoilenko, S. V. Osadcha, O. Ohanezova-Hryhorenko, L. I. Povzun, etc. - Lviv-Torun : Liha-Pres, 2020. - 136 p.

ISBN 978-966-397-201-5

\section{SENSE}

Liha-Pres is an international publishing house which belongs to the category „C" according to the classification of Research School for Socio-Economic and Natural Sciences of the Environment (SENSE) [isn: 3943, 1705, 1704, 1703, 1702, 1701; prefixMetCode: 978966397]. Official website www.sense.nl. 


\section{CONTENTS}

TIME AND MODERNITY AS CATEGORIES OF MUSICOLOGY: HISTORICAL AND SEMIOLOGICAL PARADIGM

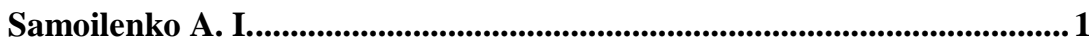

SEMIOLOGICAL ASPECT OF STUDYING THE STRUCTURE AND CHRONOTOPIC FEATURES OF THE ORTHODOX LITURGICAL TEXT

Osadcha S. V. 20

AUTOPOIESIS AS AN IMMANENT CREATIVE PROCESS OF THE ARTIST AND MUSICIAN

Ohanezova-Hryhorenko $O$. 37

SEMANTIC SPACES OF INSTRUMENTAL

AND ENSEMBLE PERFORMANCE:

INVENTION-TENDENCY AT THE PRESENT STAGE

Povzun L. I. 56

HISTORICAL AND PHILOSOPHICAL DISCOURSE OF MUSIC ORATORY IN THE PROJECTION OF DOMRA PERFORMANCE Oliinyk O. L. 75

POLYSTYLISTICS AS A MUSICAL PHENOMENON AND ITS AUTHOR'S MODELS

Grybynenko Ju. O. 93

INSTRUMENTS-IMAGES IN MUSICAL SCIENCE AND PRACTICE

Chernoivanenko A. D. 113 
DOI https://doi.org/10.36059/978-966-397-201-5/1-19

\section{TIME AND MODERNITY AS CATEGORIES OF MUSICOLOGY: HISTORICAL AND SEMIOLOGICAL PARADIGM}

\section{Samoilenko A. I.}

\section{INTRODUCTION}

The category of time accompanies musicology at all its cognitive levels: axiological cultural and semantic, praxeological genre, musical and style textological, and finally in linguistic - as at the level of deep generative poetics of music. So, they replace one another with the forms of temporal representations that form a sequence of epistems - cognitive adjustments: "cultural time", genre time as a certain historical time of music, stylistic time as a figurative and symbolic ideational, triggering conceptualization mechanism, as well as compositional time as adjacent between the previous style and the next, linguistic, levels; the latter acts as the time and place of the direct creation and performance of a musical composition.

Through compositional time - the ways of organizing it, that is, on the border of the style and symbolic and stylistic circles, the concept of modernity acquires relevance and concretization - precisely in connection with the immanent logo of music, that is, in a conceptually "pure" and absolute meaning, like what is created in the chronologically immediate context and often still does not have completely clear, defined genre and style indicators, therefore, it requires direct comprehension of the musical text qualities - mastering, evaluations, literal presence of it; that means, analytical penetration into the musical material.

But it should be remembered that each historical epoch had this - its own - immediate modernity; so, it should be remembered that modernity is a kind of historical situation. Therefore, when referring to distant chronological musical and historical phenomena, evidence is so valuable and necessary (direct witnesses are important) in the form of listeners' reviews, critical notes, research papers, memoirs, etc.

The interaction of the value experience of music and the possibility of its semantic preservation - reconstruction, its interpretative reorganization is due to the artistic and semantic nature of time in music, that is, features of the phenomenon of musical time, growing on a 
specific linguistic basis. This phenomenon requires special study criteria, primarily the development of a historical and semiological approach.

\section{Historical knowledge of time}

Man learns from history; history, since this is the history of mankind, «learns» from man. Behind this rhetorical expression there lies the drama of a person's relationship with the time scales of life. It is a very common opinion that history has not taught anyone anything yet ... However, can we trust it?

If we compare the generic cumulative humanity with a holistic living organism, then historical knowledge appears to be its nervous system, which permeates all parts of the body, stimulates the activity of all organs and transmits signals from them to the central control organ - the brain, the functions of which in the structure of historical knowledge are assumed by its methodology. The most essential in the methodology is the clarification of the appropriateness of knowledge, that is, the answer to the question of where it leads to and what it exists for.

There is well known Plato's thought that correctly posed questions is half the training, that is, half the answer to them. Therefore, we will try to identify those derivative questions that arise when trying to answer the main methodological question about the modern significance of historical knowledge in its involvement in ideas about the humanitarian culture and its spatial and temporal coordinates - chronotopic dimensions. This also means finding the necessary and sufficient number of such questions, determining their order and categorical weight. Today, there is a need to create a dictionary of the modern historian as a broad-based humanitarian, not indifferent to the issues of the artistic functioning of culture, as an important aspect of its self-determination in the course of history. From the side of the history of art, in particular the history of music, there are significant clues regarding the true content and purpose of historical processes in their inseparability from the existence of culture, from the existence of the human person. It is no coincidence that really large historians have not passed questions about the artistic creation and personalities of artists.

Connected with the study of special artistic and creative matter, a musicologist can come closer than other art critics to the deep semantic content of human history - the phenomenon of humanity, which from the time of Confucius to the era of Bakhtin appears to be a true "factor X" in the historical evolution of man. 
The Greek word "history", which, according to V. Dahl, has long been accepted by all European languages, is interpreted as a story about events or adventures, a description of the life and circumstances of a people's life ${ }^{1}$. That means, it immediately indicates the use of the word as the main tool for historical reflection of the world, associated with the development of rational and logical forms of reality awareness; it appeals to the cognitive abilities of man, to the «space of knowledge». The word (verbal logo form) is quickly turning from an auxiliary tool into the main subject of historical cognition, a factor in the formation of the textual memory of the human community, bringing history and historiography closer to identification. The second feature of historical knowledge, which also manifests itself very early, is its breadth, providing comparison - a comparative approach, the ability to differentiate objects of historical study, but in order to identify their common significance. The extreme breadth of history and its striving for universal indicators of being is evidenced by the definition of R. Wipper: "We call history the science of the fate of the human race on earth. For this science it is easy to collect a lot of information about the times closest to ours. In an enlightened society, they are worried that there remains a memory of what has been experienced, they keep records of events and human orders. But the farther we go back in past centuries, the less such concerns, the fewer records we will meet" 2 . These words make three typical signs of historical knowledge visible, which can be attributed to the characteristics of historical reality: reliance on the real, actual, on people's lives; the use of written evidence of this life, factography because of the inability for the historian to be present directly in the past; the special importance of ancient sources and confirmation of their authenticity.

The paradoxical duality of history as a subject area of knowledge lies in the fact that its main reality is the existence of the human community in time, which forms its own course of history; but this reality arises in the displayed form - with the help of the conventionality of the verbal description, conditional content structures of texts that can be attributed to the primary sources. The foregoing explains why V. Klyuchevsky offers a "double" definition of history: as a movement in time, a process;

${ }^{1}$ Даль В. Толковый словарь живого великорусского языка. В 4-х тт. Т 2. М.: ОЛМА Медиа Групп, 2007. С. 54.

${ }^{2}$ Виппер Р. История древнего мира. В. Ю. Виппер. История древнего мира; А.А. Васильев. История средних веков. М.: Изд-во «Республика», 1993. С. 14. 
as process knowledge. In addition to the emphasis on the concept of time, as a key one, the Russian historian puts forward the concept of «human society», as reflecting the "content of history»; in his opinion, history, as a separate science, a special area of scientific knowledge should be studied, serves the historical process, that is, the course, conditions and achievements of human society or the «life of mankind» in its development and results» ${ }^{3}$.

V. Klyuchevsky creates a special theoretical concept of historical knowledge, at the center of which he places a person, but as a cultural collective being, so, in his interdependence with the properties and actions of the forces organizing the historical process, they are his "kinetics". It is this "man-science" side of Klyuchevsky's historical doctrine that forces him to ask the question about "the secret of the historical process" associated with the "energy of people development", acting on the basis of "communication and continuity" as a means of human community. The importance of the human factor in history also persists when Klyuchevsky reflects on the necessary factors for the emergence of community between people: "This is common under two conditions: that people understand each other and that they need each other... These conditions are formed by two common abilities: the mind that acts according to the same laws of thinking and by virtue of the general need for knowledge, and the will that causes actions to satisfy needs... Time consolidates the digestible heritage with a new moral connection, historical tradition...» ${ }^{4}$. We add that under the will the historian understood the psychological principle that reveals the human individuality and its personal purpose. Thus, the psychological properties of the human individual, the semantic needs of the individual, also become conditions and factors of historical time.

Therefore, the subject area of historical knowledge includes understanding, mind, will, as purely human properties that acquire a generalized - general historical - sense and determine those processes of communication and transmission of accumulated experience in which the special creative energy of the human community historical movement accumulates and manifests itself in time. The "objectivity" of the historical process thus turns around to be recognizing the driving force of

${ }^{3}$ Ключевский В. Лекции по русской истории. В. Ключевский. Собрание сочинений в 8-ми тm. Т.1. М.: Гос. изд-во полит. лит-ры, 1956. С. 14.

4 Ключевский В. Лекции по русской истории. В. Ключевский. Собрание сочинений в 8-ми тm. Т.1. М.: Гос. изд-во полит. лит-ры, 1956. С. 19, 21-22. 
the history subjects, as well as the subjective human consciousness. V. Klyuchevsky, who, incidentally, is considered as one of the most objective Russian historians, surprisingly predicts the theory of passionarity of L. Gumilev, who considered the presence of a special kind of energy (passionarity) to be the cause of ethnogenesis and changes in the ethnic development of mankind. But the main thing in Klyuchevsky's conception is that he, firstly, proves that historical knowledge does not exist and is not essential outside a person; secondly, it discovers that in unity with the knowledge of history its understanding develops, manifests itself, and this opens up the need to study historical human psychology, significant historical figures; thirdly, it expands the idea of the factual basis of historical knowledge, allowing to introduce artifacts to it - substantive evidence of the creative historically moving energy of a person, in connection with which not only verbal, but also other artistic and iconic monuments of the past and present can claim the role of "historical witnesses", conditional historical texts.

As far as subject of history to our knowledge (cognition) is conditional, then conditional semiotic ways of creating and storing, transmitting historical reality, that semantic content of the conditional culture world, the artistic world of art, which are associated with the human ability to understand and interpret, acquire a new methodological value. Therefore, S. Averintsev finds in the symbolic structures, which are inherent in a particular culture, its main historical content; he calls it "the algebra of the history of culture", noting that "the history of culture is in its essential part the history of human symbolism". In his central work "Poetics of Early Byzantine Literature", he deduces the order of history from a system of ideas about space and time. That means, he offers, inheriting in a certain sense M. Bakhtin's positions, worldview chronotopic dimensions of the historical process, deepening the understanding approach of historical knowledge ${ }^{6}$.

Thus, the symbolic conventions of culture, which affects artistic forms and artistic consciousness, determine the main historical realities, artifacts - primary evidence, connects the "written" (subject and material) with "oral" (ideational) sides of the historical process. Moreover, as directly "understanding", the oral side of historical memory

5 Аверинцев С. К уяснению смысла надписи над конхой центральной апсиды Софии Киевской. С.С. Аверінщев. Софія-Логос. Словник. К.: Дух і література, 1999. С. 214.

${ }^{6}$ Аверинцев С. Поэтика ранневизантийской литературы. М.: «Сoda», 1997. 
is deeper and more socialized; it indicates the fundamental basis of historical consciousness.

When we talk about the "oralness" of history, we mean, first of all, not only the oral verbal plan of culture, but also the whole totality of extra-symbolic forms, forms of artistic creativity; and secondly, the semantic content of the historical process that remains outside opportunities of well-known iconic structures, but interacts with them as a phenomenon of deep cultural memory - the collective unconscious. Actually, it is to this plan of social memory that the historical and cultural theory of $\mathrm{O}$. Spengler, tinted by art history, is addressed, as well as the autobiographical concept of the history of N. Berdyaev. Spengler defines world history as "some spiritual opportunity," "some expression of the form sense," as "the image by which a person's imagination wants to gain an understanding of the world living being in relation to his own life and thus provide it with an in-depth reality" ". In his interpretation of the history mechanism, the psychological abilities of human consciousness - imagination, understanding, feeling and experience also turn out to be tools of knowledge.

N. Berdyaev represents the historical process as already fully personified and individually psychologized, revealed in a dramatic clash with personal will: "I survived the world, the entire world and historical process, all the events of my time as part of my microcosm, as my spiritual path ... <.. > .. I had to live in a catastrophic time both for my homeland and for the whole world. In my eyes whole worlds collapsed and new ones arose. I could observe the extreme inconstancy of human destinies ...<... ... History does not spare the human personality and does not even notice it» ${ }^{8}$. Today we know that history "noticed" Berdyaev, who was included in the list of the most prominent thinkers of the first half of the XX century.

Understanding the historical process as a human "act by life" (M. Bakhtin) not only strengthens and deepens the psychological criteria of historical knowledge, but also allows to propose the nomination "homo istoric" - "historical man" (that N. Berdyaev was, in particular), thereby recognizing human authorship in history and the dependence of

${ }^{7}$ Шпенглер О. Закат Европы: Очерки морфологии мировой истории. Т. 1 Образ и действительность. Пер. с немецкого Н.Ф. Гарелин. Мн.: ООО Пупурри, 1998. C. $20 ; 10$.

${ }^{8}$ Бердяев Н. Самопознание. Сочинения. - М.: ЗАО Изд-во ЭКСМО-Пресс; Харьков: Изд-во Фолио, 1999. С. 252-253. 
personality being in time on the general state of temporary consciousness of culture, on its chronos.

Trying to take into account and combine all the factors and forms of the historical process, suggesting its semantic attitudes, and also identifying personal needs for historical self-determination, recognition, today's historical knowledge is increasingly turning into historiology of culture aimed at determining the theoretical principles of the temporal and spatial dimensions of history, including - at the study of art chronotopes. According to M. Bakhtin, it is they who form the "gateway to meaning". That is why, attention to them contributes to the development of an understanding tendency of humanitarian knowledge, allows to combine quantitative and qualitative factors, indicators of historical thinking'.

Chronology, with its meticulous and rigorous relationship to dates and the digital timing of history, not only remains a necessary component of historical memory; it requires the special ability of the historian researcher to reproduce the order of events and facts, to feel the "aesthetic correctness" of this order, special historical imagination, which manifests itself in working with numbers (numerical indicators). Interesting and accurate are the comments on this subject by R. Wipper, who, in particular, writes: "Chronological memory forms a rare special ability: with respect to the vast majority of students, teaching chronology is a completely useless exercise" 10 . Precisely because chronology teaches the historical temporal order, it needs an arrangement and ordering of dates, related events, facts, names in the conditional space of culture, which appears to be nothing more than a space of human activity and creative self-fulfillment, that is, a space of human actions - as an expression of responsibility for life, for human behavior and the implementation of certain ethical principles that are indicative of a given historical type of culture.

If chronology recreates the immanent logos of history (immanent, but laid down in it by subjective human efforts to master being), then the study of the spatial coordinates of cultural life (ethnic interethnic, social transpersonal, psychological immanent-personal, in the end - artistic

9 Бахтин М. Формы времени и хронотопа в романе. M. Бахтин. Bonpocbl литературь и эстетики. Исследования разных лет. М.: Художественная литература, 1975. С. 234-407

${ }^{10}$ Виппер Р. История древнего мира. В. Ю. Виппер. История древнего мира; А.А. Васильев. История средних веков. М.: Изд-во «Республика», 1993. С. 12. 
interspecific, intergeneric, interstyle), so to say, the spatiology of culture allows us to objectify the components of the historical logos, to find the symbolic functions of the historical world order, to recreate ethos and pathos of history.

In this regard, musical art turns out to be that mirror of historical knowledge (mirror reproduction of historical reality), which is more pleasant and useful for a person to look into than any other... Therefore, it can be considered that musicology can provide significant chronotopic support to historiology, which means - support in the main question of the appropriateness of historical knowledge - the sense of history.

This question, or rather, the search for a system of answers to it, needs to define such a dictionary of historical categories that would meet the interests of modern humanities, including musicologists. Presumably, it contains three groups of categories, of which the first indicates the objective content of historical knowledge, the second indicates the forms and tools of its translation, and the third indicates methods of development, respectively, the appropriateness of historical knowledge.

The first group includes the following categories:

the course (movement) of history - historical reality;

knowledge of history - understanding of history;

historical convention and conditional history;

historical sources, first evidence;

oral and written history.

The second group includes categories such as:

historical consciousness and imagination;

homo istoric - historical man;

historical time - the time of history (chronology - periodization, quantitative and qualitative indicators of historical time);

historical chronotopes.

The third group consists of the following categories:

historical memory, historical thinking;

the history of culture - the history of personality;

the history of psychological knowledge - the history of human consciousness (of higher psychological functions);

the sense of history.

The sense of history (its true sense) on the part of an individual person is the reproduction of the beauty of time in personal consciousness, the aesthetic transformation of human memory, which is included in the memory of culture with special structures; it harmonizes 
its space, provides it with the beauty of humanity. From the side of history - the historical state of culture - this is an increase in the value of an individual person life and of the human community as a whole - the human «common life», the increment of the general human mind, the strengthening and ennobling of individual manifestations of will.

\section{Modernity as a form of interpretative time and the language of music}

The spectrum of phenomena that the concept of modernity embraces is very wide. It involves the inclusion of such a phenomenon as the artistic time of culture, implying dialogicity in temporal and spatial relations. Today - and this is an attribute of the present modern to us the concept of modernity acquires an independent status of interpretative time - as a personality and psychological time of interpretation with its own semantic components and resonances.

The phenomenon of interpretative time combines the globalization of space and the mythologization of temporal attitudes, representations; it is included in all musical-creative and musical-reflective forms composer, performer, listener, musicology. It becomes indicative of that particular current historical situation, which today is most often defined as postmodernity - the postmodern state of culture and art. This situation presupposes an in-depth conceptualization associated with the separation of personalized and psychological time, with its individual-subjective symbolization (of course, typological features also appear in it, but this trend is not obvious, that is, it does not lie on the surface - it has not crystallized). Modern interpretative time can be considered as an analogy of the situation "Waiting for Godot"...", that is, as the effect of existential expectation - tension, requiring special semantic projections. The transformation of modernity concept into the neologism "postmodernity" is explained by the need to find a way out of this state of intense expectation, as an experience of temporary uncertainty, the loss of a temporal value center.

As A. Alferov rightly writes, "the modern historical situation will be replaced by some new situation. When this transition will happen, we do

${ }^{11}$ Напомним, что так называлась пьеса ирландского драматурга Сэмюэля Беккета, в английском варианте имеющая подзаголовок «трагикомедия в двух действиях». признанная самым влиятельным англоязычным драматургическим произведением XX века. 
not know, perhaps we have already entered it. What will it lead to, to whom and to what does the near future belong? V. M. Mezhuev rightly observes: "The situation of uncertainty created by this transition, as it were, equalizes everyone in the consciousness of their "non-modernity", makes us doubt the superiority of any identity, no matter who it is today", 12

These words of the modern culturologist reflect the main contradiction that arises when referring to the concept of modernity: the rapprochement of the categories of modern and historical, which hinders the clear identification, isolation of a segment of historical time as just and only modern; the inclusion of non-modern phenomena and representations, characteristics in the content of modernity, and most importantly - the lack of clear boundaries of time and space, the loss of a sense of temporal identity - a change in the very nature of this feeling leads to a profound transformation of temporal historical consciousness.

The concept of postmodernity significantly complicates the categorical position of the terms of time and modernity. As A. Matetskaya writes:

"The truth is no longer indisputable. They began to interpret it in the spirit of the practical needs of the institutions of society; ...the place of TRUTH is occupied by the "multitude of truths", and there is no longer any generally accepted way of choosing among the elements of this multitude. ... What should I do, how should a person of the post-modern era feel when the concept of truth has disappeared, when you can't be sure of anything and you can't know anything for sure? When many points of view coexist on equal terms, and no one can be sure of the correctness of the choice made... According to the theorists of postmodernism, a person simply "plays", enjoys life in all its diversity, since a post-modern society provides him with a huge amount of benefits and services. The man of postmodernity is much freer than people who lived in earlier eras. Freedom is manifested in everything: from the way of thinking and ways of expression to movements around the world and relations between the sexes. However, unlimited freedom of choice turns into freedom from oneself - a problem of identity crisis" ${ }^{\prime 13}$.

12 Алфёров А. Современность: два среза понятия. Информационный гуманитарный портал «Знание. Понимание. Умение». № 3. 2011.

13 Матецкая А. Социология культуры. Учебное пособие. Ростов-на-Дону: Феникс, 2006. С. 120-121 
The musical identification of historical time is a process of correlation and mutual objectification of representations of time and the iconic means of music, "spirit and letter", as a key antinomy of semantic reality of a person; it can be considered as a way to overcome the identity crisis, because it occurs in accordance with the antinomic rule of S. Averintsev (correlating the order of the cosmos - the order of history) as follows: the order of sense formation (understanding, style of worldview) determines the order of music, then its own internal order of knowledge about music is inevitably becoming historical and historically significant.

The words of St. Augustine testify most clearly to the connection of time and spirit: "Time exists only in our soul. The past is in the memory, the future is waiting...; the essence of the present tense is contemplation...; in you, my soul, I measure time. The impression of passing by remains in you, and it's something that now exists, I am measuring... I am measuring the impression (experience - A. S.), measuring time...; it seems to me that time is nothing but a stretch. But the extension of what exactly - I do not know with certainty, although it is unlikely that it would be anything other than the extension of the spirit itself" ${ }^{\prime 14}$. It is time that acts as the main existential of man and the human community; relations with time form deep "impressions" - experiences that are stored in memory.

Relations with time are modernity in its broadest sense, as an indication of sustainable ways of assigning and adapting, organizing and reorganizing time - ideas about time, and, therefore, time is conceptual.

The most familiar idea of the present - as the closest time dimension, the personality and individualized life parameter of the time process - is also the result of the conceptualization of time as the present (and, in Augustin's style, as the present present, present past and present future).

The cultural and aesthetic categorical significance of the concept of "modern" is determined by many factors. First of all, it points to a special artistic and aesthetic phenomenon, closely associated with attitudes and needs, the semantic dominants of modern culture. But it is not less addressed to those value realities of the cumulative human experience that have acquired the status of historical universals, that is, the premature - metatemporal - purpose. Also indicative of it is the

${ }^{14}$ См.: Таранов П. Анатомия мудрости: 120 философов: В 2-х томах. Симферополь: Реноме. 1997. Т. 1. С. 471. 
tendency to overcome the psychological cognitive and emotional crisis, in particular, the return to the interest in classical art forms, which can be seen as an attempt to update the «emotional matrices» of culture.

Consequently, from the general aesthetic and cultural side, the concept of modern, combined with the prefix "post", characterizes not so much the time of creation of the works as their socio-communicative status, as well as the performing side of musical creativity. So, for example, the repertoire that defines the performing practice of the opera house today is considered modern, regardless of the «age» of the opera works and even the degree of their staged novelty. In relation to musical theater, the category of (post) modernity becomes purely nominative and formal; its deeper artistic and aesthetic justification should not be sought in the general repertoire system, or even in directorial and production decisions, but in the combined image of an opera character - a true "hero of a work", a reference "hero of his time". The latter circumstance puts forward in the first row the criteria of the musical art present as an integral artistic and creative phenomenon, the figure of a performer, musician and artist.

However, the decisive criterion for the contemporary art of music, including the possibility of raising this concept into the meta-sphere of postculture, remains its linguistic matter, means of thinking and speech interpretation, that is, a specific musical logo.

As it was pointed out by Y. Kholopov, the musical logo is not being, but the secret of music. We say: the musical logo is both being and the secret of music. That means, it represents the secret immanent nature of music, which provides it with a unique sense-organizing role.

The existential basis of the musical logo is the "meeting" in music of three forms of time (as forms of musical comprehension and representation) - the historical "cultural time", personal psychological time and personal musical time - the immanent logic of the musical temporal process. Each of them contributes to the formation of musical content; the latter is an integrating and completing "effort" of the previous ones, translating them to the level of "musical thought".

The concept of Y. Kholopov ${ }^{15}$, who draws attention to particular dynamism in the development of European music of recent decades and

15 Холопов Ю. Изменяющееся и неизменное в эволюции музыкального мышления. Проблемы традиции и новаторства в современной музыке. М.: Сов. композитор, 1982. С. 52-104. 
offers a periodization of the history of European music from the point of view of the most important updates occurring in it, focuses on this interaction mainly in its substantive content (noting the beginning of the XI century as key temporal points - the work of Guido Aretinsky; the beginning of the XIV century - the work of Philip da Vitry; the beginning of the XVII century - the creative innovations of Giulio Caccini and the beginning of the XX century, marked by heuristics of Anton Webern).

According to Y. Kholopov, "accelerated updates are inherent in musical history. It is no coincidence that the Middle Ages and the Renaissance are often combined into one whole; but they cannot unite with each other the Renaissance and the New Time (1600-1900). Inside the XX century, both halves of the century are already sharply different. The swift evolution of musical thinking in our era is a universally recognized fact that does not need proof. All the music of the $\mathrm{XX}$ century seems to be a grand cataclysm, shaking the very foundations of traditional musical thinking. The adjacent short links in the long chain of changes are very similar to each other, the non-adjacent ones no longer seem to belong to the same chain..."

Regarding the category of modernity, without using the term itself, Kholopov quite accurately describes the prerequisites for the formation of this concept and its possible contradictions, when he notes that people of every time tend to experience especially acutely what is happening in front of their eyes, events that are close to them, whereas from a long temporal distance "everything looks very different: ars nova is difficult to distinguish from ars antiqua, Dufay's polyphony is included in a" strict letter "along with Palestrina's polyphony, and we may soon find it difficult to distinguish between the harmony sound of Berg and Rachmaninov». But Kholopov is also looking for those "great breaks in musical history" that make it possible to identify the ontological connections of the musical language and the semantic intentions of cultural consciousness; he notes that at the modern, that is, at "our" stage of musical art development, the most important thing is the phenomenon of a musical composition, for which the following compositional laws are valid: "The presence of thought, the corresponding division and

16 Холопов Ю. Изменяющееся и неизменное в эволюции музыкального мышления. Проблемы традиции и новаторства в современной музыке. М.: Сов. композитор, 1982. С. 52-104. URL: http://www.kholopov.ru/izm/. 
subordination of parts, a certain... time of experiencing music, definite time distribution"; in connection with them, the high-altitude system (as the basis of the sound structure of the composition) and the rhythm acquire special logical functions, since it is they that force people to go deeper into the music, "inside" its semantic content ${ }^{17}$.

According to $\mathrm{Y}$. Kholopov, the entire musical composition is permeated by the relations of musical logic (correspondences, symmetries, proportions, dimension, proportionality), including rhythm, harmony, counterpoint, form, and "beauty as a reflection of numerical order penetrates the musical-sound whole from top to bottom, generalizing with the radiance of a beautiful whole image". The central postulate of the research by $\mathrm{Y}$. Kholopov provides for the following theoretical positions:

- the history of music is the logic deployment of sound relationships; it is "time-becoming logic" measured by "musical numbers";

- "musical numbers", where the musical interval is representative ( 1 = unison and octave, 2 = fifth and fourth, 3 = third and sixth, etc.), arise as "generalized structures of consciousness that objectively arise in the process of its historical evolution in connection with public life practice";

- meaningfully, "musical numbers" are "coefficients of the consciousness level"; they arise in the process of «all material and intellectual activity of man», but they also become creatively initiative principles. That means, they are capable of «acting» into the world around them, to transform it;

- the basis of «musical numbers», therefore, the logo of music, aesthetic ideas about the purpose of a person and his consciousness, his sense-generating properties; therefore, «each subsequent highest number is what could be called: a new man - and - a new ideal».

According to Kholopov's theory, the aesthetic center of the musical and historical evolution of consciousness is time objectification in music - investing temporary content in a certain sign form, therefore the aesthetic (semantic) center of music forms its chronotopic sign thesaurus.

17 Холопов Ю. Изменяющееся и неизменное в эволюции музыкального мышления. Проблемы традиции и новаторства в современной музыке. М.: Сов. композитор, 1982. С. 52-104. URL: http://www.kholopov.ru/izm/. 
Its main qualitative indicators are inseparable and non-merged, both in horizontal deployment and in the vertical volume of musical tissue - this is the basic law of a musical text sound device, which reached its utmost expression in the $\mathrm{XX}$ century in dodecaphony and pointillism; dodecaphony is focused on the absolutization of non-fusion, and sonoristics - on the totality and absoluteness of inseparability. The interaction and opposition of these principles determines the development of one's own matter of music - musical fabric, texture to the same extent that the assimilation of the united or the unity of differences is the principle of harmony, and the unification of the unmatched or the difference of the one is the principle of polyphony. There is a methodological similarity between these technological areas, but they are not symmetrical, because they have different goals - the first reveals the possibility of merging and the absolute merging; the second is the possibility of non-fusion and its regularity, importance. But both this and the other are related to the attitude to the temporal order of music, that is, to the order that music brings to the relationship of a person with time.

Therefore, V. Martynov is not quite right, when he writes that time is absent in Palestrina's music, since space is united and not divided, and space in Beethoven's compositions, due to its unlimitedness and continuity, ceased to play the formative role that it played in Bach: he essentially draws attention to various forms of musical and textual ordering of time - polyphonic and homophonic-harmonic ${ }^{18}$.

\section{CONCLUSIONS}

In general, the term "modern" is ambiguous, it is able to indicate several temporal dimensions: the historical time of music creation, that is, modernity for its author; modern readings of a musical composition, that is, the form of a historical dialogue with a musical concept; finally, the current state of the music art, including the creation of fundamentally new musical and linguistic resources of musical compositions and methods, forms of performance.

Thus, historical time and "modern" time show a coincidence, especially noticeable in musical form.

18 Мартынов В. Время и пространство как факторы музыкального формообразования. Психология художественного творчества. Минск: Харвест, 2003. С. 130-144. 
From the standpoint of semiology, musical time is constituted by the general time of culture as the assimilated experience of a person's relationship with time, the cultural and historical typology of temporal modality. But even more, it is determined by the relation of musical sound to sense, and sense to sounding (including its "non-sounding" structures, "weightiness", in the terminology of M. Arkadiev) form of music, representing a specific non-verbal form of musical thinking.

Time and sense in music have common dimensions - "deep structure" and "surface structure", if we use L. Hakobyan's approach to the rhythmic organization principles of music and its terminology. Moreover, the rhythm, which, thus, becomes the main essential characteristic of both time and sense, can be considered as the connecting link of the data of two dimensions. Therefore, the definition of "deep structure rhythm" proposed by Hakobyan is equally valid with respect to both (time and sense in music): "The rhythm of the deep structure should be understood as its characteristics that determines the time distribution of the paradigmatic and syntagmatic positions of the elements included in composition of the surface structure" ${ }^{\text {"I }}$. In addition, Hakobyan especially emphasizes that «the fundamental difference between the rhythm of the deep structure and the rhythm of the surface structure (that is, from the category "rhythm" in the more familiar sense...) is that the former is continuous, while the latter is discrete" 20 .

Consequently, the rhythm common to sense and time formation in music also turns out to be "visual" and "invisible, secretive"; installation and resulting moments rising «above» (or going far deeper) in relation to the given «surface» of the composition, at the same time, by this very «surface» - as a combination of textural and spatial techniques for presenting a musical text. In other words, rhythm, becoming musically pronounced, stands in solidarity with the spatial form, although it does not become it to the end - and precisely because of the determining role of the "deep" rhythmic sense.

It is no coincidence that A. Losev singled out immanent time factors that do not go over to the side of spatial conditions - rhythm, symmetry, metro-rhythmic accent - and called them necessary musical categories dialectically arising from the expressive element of "pure number", if the

19 Акопян Л. Анализ глубинной структуры музыкального текста. М.: Практика, 1995. С. 88.

${ }^{20}$ Там же. 
latter consistently distinguishes moving peace, self-identical distinction and individuality ${ }^{21}$. Taken at various levels, in different volumes of the composition, they express an autonomous temporal idea of music, and the temporal factors of the musical composition are elevated to the value of "higher order rhythm".

\section{SUMMARY}

The article explores the sense of the category of time and the concept of modernity derived from it in modern musicology, defines methodological levels and discursive forms due to various methods of studying the time phenomenon. The concept of postmodernity is considered as an actual humanitarian term characterizing the new relationship of a person with historical time; the temporal possibilities of musical art, due to its artistic and iconic nature, are analyzed.

The study of historical knowledge principles, representing the total time of human experience, allows us to substantiate the importance of the symbolic memory of culture as the basis of worldview chronotopic dimensions of the historical process, guarantees its semantic content. The symbolic conventions of culture are considered in connection with the semantic experience of music. It is proved that the possibilities of interpretative reorganization of time in music are due to its special artistic and semiological nature; the phenomenon of musical time grows on a specific linguistic basis, therefore, it suggests autonomous learning criteria.

The development of the historical and semiological approach allows us to develop the concepts of chronology and spatiology of culture as indicators of our own logos of history, to determine the role of musical art as a mirror of historical knowledge, to offer a system of musicological categories corresponding to this, indicating the subject content of historical knowledge; the forms and tools of its broadcast; the methods of development, respectively, the appropriateness of historical thinking in music.

The role of interpretative time in musical-creative and musicalreflexive forms is discussed; it is noted that the phenomena of modernity - postmodernity acquire a paradigmatic significance in musical art; they are associated with the musical language evolution. The

21 Лосев А. Музыка как предмет логики. А. Ф. Лосев. Форма. Стиль. Выражение. Сост. А.А. Тахо-Годи. М.: Мысль, 1995. С. 552-553. 
most productive musicological approaches to the temporal order of music are determined, the socio-communicative features of the modern post-modern position of musical art are examined, as well as the principles of sense and time formation in music, in particular the originality of the musical rhythm.

\section{REFERENCES}

1. Аверинцев С. К уяснению смысла надписи над конхой центральной апсиды Софии Киевской. С.С. Аверінщев. Софія-Логос. Словник. К.: Дух і література, 1999. С. 214-243.

2. Аверинцев С. Поэтика ранневизантийской литературы. М.: «Coda», 1997. $343 \mathrm{c}$.

3. Акопян Л. Анализ глубинной структуры музыкального текста. М.: Практика, 1995. 256 с.

4. Алфёров А. Современность: два среза понятия. Информационный гуманитарный портал «Знание. Понимание. Умение». №3. 2011. URL: http://zpu-journal.ru/ e-zpu/2011/3/Alferov_Modernity/

5. Бахтин М. К методологии гуманитарных наук. М. Бахтин. Эстетика словесного творчества. М.: Искусство, 1986. С. 381-393.

6. Бахтин М. К философии поступка. М. Бахтин. Работы 1920-х годов. К.: Наукова думка, 1994. С. 9-68.

7. Бахтин М. Формы времени и хронотопа в романе // Вопросы литературы и эстетики. Исследования разных лет. - М.: Художественная литература, 1975. - С. 234-407.

8. Бердяев Н. Самопознание. Сочинения. М.: ЗАО Изд-во ЭКСМО-Пресс; Харьков: Изд-во Фолио, 1999. 624 с.

9. Виппер Р. История древнего мира. В. Ю. Виппер. История древнего мира; А.А. Васильев. История средних веков. М.: Изд-во «Республика», 1993. С. 14-244.

10.Гессе Г. Игра в бисер. М.: Художественная литература, 1969. $418 \mathrm{c}$.

11.Даль В. Толковый словарь живого великорусского языка. В 4-х тт. Т 2. М.: ОЛМА Медиа Групп, 2007. 672 с.

12.Ключевский В. Лекции по русской истории. В. Ключевский. Собрание сочинений в 8-ми тm. Т.1. М.: Гос. изд-во полит. лит-ры, 1956. $328 \mathrm{c}$.

13.Лосев А. Музыка как предмет логики. А. Ф. Лосев. Форма. Стиль. Выражение. Сост. А.А. Тахо-Годи. М.: Мысль, 1995. C. 405-602. 
14. Мартынов В. Время и пространство как факторы музыкального формообразования. Психология художественного творчества. Минск: Харвест, 2003. С. 130-144.

15. Матецкая А. Социология культуры. Учебное пособие. Ростовна-Дону: Феникс, 2006. 260 с.

16.Самойленко А. Время или пространство музыки: полемические аспекты проблемы музыкальной темпорации. Київське музикознавство. Вып. 21. К., 2007. С. 11-27.

17. Соловьёв В. Сочинения: В 2-х тт. 2-е издание. Общ. ред. $u$ сост. А.В. Гулыга, А.Ф. Лосев. М.: Мысль, 1990. Т. 2. 822 с.

18. Таранов П. Анатомия мудрости: 120 философов: В 2-х томах. Симферополь: Реноме. 1997. Т. 1. 624 с.

19. Холопов Ю. Изменяющееся и неизменное в эволюции музыкального мышления. Проблемь традиции и новаторства в современной музыке. М.: Сов. композитор, 1982. С. 52-104. - URL: режим доступа: http://www.kholopov.ru/izm/

20.Шпенглер О. Закат Европы: Очерки морфологии мировой истории. Т.1 Образ и действительность. Пер. $c$ немеикого Н.Ф. Гарелин. Мн.: ООО Пупурри, 1998. 688 с.

\section{Information about the author:} Samoilenko A. I., Doctor of Arts, Professor, Vice-rector for Scientific Work, Odessa National A. V. Nezhdanova Academy of Music 63, Novoselskogo str., Odessa, 65023, Ukraine 


\section{SEMIOLOGICAL ASPECT OF STUDYING THE STRUCTURE AND CHRONOTOPIC FEATURES OF THE ORTHODOX LITURGICAL TEXT}

\section{Osadcha S. V.}

\section{INTRODUCTION}

The problem of the text arises and begins to be actively discussed by the scientific community in the second half of the XX century. It is not traditional for musicology; questions of textual analysis are rather indicative of cultural studies, since many aspects of not only the artistic, but also the life process are associated with the concept of text. However, their relevance for musicologists is becoming increasingly apparent. This is confirmed by the growing interest in this problem in the publications of both domestic and foreign musicologists. These publications indicate that musicology is following the path of mastering the already accumulated scientific experience in related fields of humanitarian knowledge and is trying to develop its own methods for studying the text and its conceptual system. The theoretical basis of musical textology is developed in their works by A. Hakobyan, M. Aranovsky, N. Gerasimova-Persidskaya, Y. Gribinenko, E. Zinkevich, I. Kokhanik, V. Moskalenko, A. Samoilenko, S. Tyshko, S. Ship and some others. Among the statements of these works, two main trends can be distinguished: in some studies, the structural and compositional approach to the study of a musical text is taken as a basis in which it appears as the musical composition text; in others, attention is focused on the genre and style nature of the musical text phenomenon, on the use of various methods of stylistic interactions by composers; therefore, the significance of music as a text that goes beyond the boundaries of individual compositions and explains the intertextual features of the musical language is revealed.

This duality of the musicological approach to the text can be regarded as a reflection and continuation of the dual attitude to the text in general humanitarian disciplines.

Studying the general trends that have been developing in textology over the past decades, it can be noted that textology is more and more beginning to be regarded as a discipline that has independent and very 
large tasks. These tasks can be formulated as follows: textology aims to study the history of the text of the monument at all stages of its existence in the hands of the author and in the hands of his scribes, editors, compilers, that is, throughout the entire time that the text of the monument was changing. Only through a complete study of the history of the text of the monument as a whole, and not by episodic criticism of individual places, can the restoration of the original author's text of the monument be achieved. Textology opens up tremendous opportunities to study schools, trends, ideological movements, changes in style, the dynamics of the creative process and is an arbiter in resolving very many disputes that, outside the study of the concrete history of texts, could have stretched without prospects for their final resolution.

\section{Textology as a modern humanitarian discipline and its tasks in the field of Orthodox singing tradition}

Since the nascence of Christianity, liturgical singing, or "music of worship," has occupied a very special place in the history of world culture. This tradition develops according to special laws, in accordance with the general task of the pragmatics of worship. If the reason for the angelic singing is "an excess of grace," then the reason for the emergence of music is rooted in the loss of grace immediately following the fall of the man. After being expelled from paradise, a man who found himself in a world full of passions began to experience not only bodily hunger and illness: spiritual hunger became even more noticeable; it was caused by the loss of communication with God. The beginning of Christian church singing, as well as the beginning of Christian worship, is sanctified by the example of Christ Himself, who ended the Last Supper by singing psalms: And, having sung, they went to the Mount of Olives (Matthew 26, 30). In interpretations of the psalms, St. John Chrysostom supplements: "The Savior sang, so that we would sing in this way». At the Last Supper, the Savior himself establishes the fulfillment of the Eucharist sacrament and the need to accompany the liturgy with singing - "do this in remembrance of me" (Lk. 22, 19; 1 Cor. 11,$24 ; 1$ Cor. 11,25$)$. In most studies devoted to the study of the 
Orthodox liturgical and singing tradition, the authors agree that this moment can be called the beginning of Orthodox liturgical singing ${ }^{1}$.

Since that time, singing has become an integral part of Christian worship. The correct melodic rank, the right life, is formed by the inseparable "triple composition" (V. Martynov's term) of liturgical singing, comparable to the three-component structure of a person, consisting of body, soul and spirit. Talking about the body of liturgical singing, V. Martynov suggests to mean the singing component of the liturgy, or rather, specific melodies of liturgical chants in their totality; talking about the soul of liturgical singing, the researcher means the Charter, or Typicon, which not only organizes the life of a Christian, but also indicates the place and time of each particular melody in the mass; talking about the spirit, finally, he means an ascetic feat, «the crown of which is the acquisition of the Divine Order, or deification, and the result is a righteous order of life that generates proper singing» ${ }^{2}$. Any areas of art related to the field of liturgical singing can be correctly understood only when they are examined from the point of view of each of the three levels listed above. From this arises, according to the opinion of V. Martynov, the need for a three-stage study, analysis and description of liturgical singing.

Martynov's concept is a prerequisite for determining the specifics of textology in the field of Orthodox singing tradition insofar as it indicates its polynuclearity, multi-levelness, on the one hand, and indicates the special position of singing experience within this tradition, on the other. At the same time, Martynov is so «free» to interpret the history of liturgical singing and the cultural facts associated with it, that literally using his terminology, his approach is not possible. It becomes quite obvious that the main textual task in the field of liturgical singing is to determine the phenomenon of the liturgical text, that is, the answer to the question of what a liturgical text is and what the functional significance of its singing side is.

1 Гарднер И.А. Богослужебное пение русской православной церкви. Сущность. Система. История. Т. 1. - Сергиев Посад : Московская духовная академия, 1998; Матвеев Н. В. Хоровое пение. История русского церковного пения. - Электросталь : Издательство братства во имя святого князя Александра Невского, 1998; Мартынов В. История богослужебного пения. Учебное пособие. - М. : РИО Федеральных архивов; Русские огни, 1994.

2 Мартынов В. История богослужебного пения: учебное пособие. - М. : РИО Федеральных архивов; Русские огни, 1994. 
Based on the understanding of the text as a delimited, completed and structurally stable autonomous cultural and semantic phenomenon (according to Y. Lotman), we can assume that, being formed historically, the liturgical text is historically independent, constant structural, including spatial and temporal connections of three main levels of the Orthodox tradition: action - ordinance; pronouncing the liturgical text; finally, the musical and singing intonation of the verbal text when pronouncing it.

In other words, the liturgical text is a simultanic unity of the ritual and pragmatic, prayer and musical aspects.

The fundamental, basic level of the liturgical text is the church action, which includes objects of worship, attributes of ordinance, vestments of priests, etc., that is, the practice of ritual as a necessary component. Its direct implementation and materialization determine the structure of the verbal and musical sides, they are the strictest and obligatory; developing first of all, they are not subject to temporary changes. However, it should be remembered that the apparent immediacy of the liturgical church action is a generalization, mediation, materialization of important religious ideas.

The ritual order is a symbolic action; it bears in itself a logical religious symbolism. In this regard, the prayer level of the liturgical text explains the symbolic nature of the ritual action creates a kind of commentary on it, points to the moments of movement and pauses in worship, its internal dramaturgy, and also the processes that occur in the consciousness of those present at the Liturgy.

The text as a principle of organization and functioning of a certain system of human activity can be revealed and justified only with the involvement of historical assessments. These estimates are also necessary when characterizing the genre and style features of the text. D. Likhachev in his study "Textology" indicates that textology was mainly defined in the works of Russian researchers of the Soviet period and in the West as "a system of philological devices" for the publication of monuments and as "applied philology". For the publication of the text, only the "original", "genuine" text was important, and all other stages of the history of the text were of no interest; criticism of the text was in a hurry to jump over all stages of the history of the text to the original text to be published, and sought to develop various "methods", mechanical methods of "getting" this original text, considering all its other stages as erroneous and not authentic, not of interest to the researcher. Therefore, very often the study of the text was replaced by its "correction". The 
textologist tried to achieve a particular result, to «get» a particular text without carefully studying the entire history of the composition text as a whole" 3 .

Initially, it seemed, as D. Likhachev writes, that textology did not have such complex tasks that the relationship between texts can be solved with simple and uniform methods. It developed separately, and it seemed that the textologist was closed in solving his narrow tasks. Deepening into the tasks of publishing a text, textology, as noted above, was increasingly forced to study the history of the compositions text. It became a science about the history of the composition text, and more broadly - about the history of the text of culture. The historical approach to the text, which, among other things, makes it possible to characterize the text as a historiological category, is the main way to discover the text in its wide sense, including due to the ascent to the original samples of the text that determine its canonical properties.

Strictly speaking, the phenomenon of intertextuality cannot be characterized with sufficient completeness in a non-historical way, that is, through only abstract theoretical analysis. And finally, given that all researchers are unanimous in recognizing as the most important chronotopic functions of the text, it should be emphasized that its temporal nature should be studied not only in a composite, but also in a comparative historical way, especially when it comes to complex, integral semantic structures, to the texts of the «special kind».

In our case, this approach is necessary, since with its help it became possible to consider the Orthodox mass as a whole as a special text. The Orthodox singing tradition, which in itself can be studied as a complex textual device, is part of a more general, complexly organized textual whole. In turn, this whole, that is, the Orthodox liturgical system, can be considered as one of the subsystems of culture, and, following the thought of P. Florensky, the central, essential part of culture. Consequently, the Orthodox singing tradition is equivalent in relation to a number of signs of the functioning of culture - both as a kind of a general universal way of human existence, and as a certain historical model of human activity. In this regard, some provisions of the cultural works of Y. Lotman are very relevant for determining the communicative features of Orthodox worship.

3 Лихачев Д. С., при участии А. А. Алексеева и А. Г. Боброва. Текстология (на материале русской литературы X-XVII вв.). С-Пб.: Алетейя, 2001. С. 31-32. 
The main and initial prerequisite for Lotman is an understanding of culture as a text, and, hence, consideration of the text in the "open" space of cultural codes. It is necessary to recall that the emergence of a special kind of texts, such as "ritual", "rite", "action", according to Y. Lotman, leads to complex problems of "transcoding, equivalence, shifts in points of view, combining different "voices" in a single textual whole»". The next heuristic step, Y. Lotman calls the appearance of literary texts «polyphonic material receives additional unity, retelling in the language of this art» ${ }^{5}$.

The dynamics of literary texts has a polar orientation: on the one hand, to an increase the integrity and immanent isolation of literary texts, and on the other, to an increase in internal semiotic heterogeneity, the development of structurally contrasting subtexts in a literary text, which, in turn, can show more and more autonomy. Under these conditions, the function of the text is much more complicated and includes a number of process levels. Y. Lotman identifies five levels, namely:

1. Communication between the sender and the addressee, in which the text acts as a message sent from the information carrier to the audience.

2. Communication between the audience and cultural tradition, where the text serves as a collective cultural memory. Important qualities of this function are, as Lotman calls, on the one hand, the ability of the text to continuously replenish, and on the other hand, to actualize some aspects of the information embedded in it and almost forget others completely.

3. Communication of the addressee with himself (self-dialogue), in which the text actualizes certain aspects of the addressee personality. This text function is especially characteristic of ancient, canonical, sacred texts. During such communication of the recipient of information with himself, the text assumes the functions of a mediator, contributing to the restructuring of the personality, changing its internal selforientation and the degree of its connection with metacultural constructions.

4. Communication of the addressee with the text in which a highly organized text, showing intellectual properties, ceases to be only an

4 Лотман Ю. Семиотика культуры и понятие текста. Ю. Ломан. История и типология русской культуры. С.-Пб.: Искусство-СПБ, 2002. С. 159.

5 Лотман Ю. Семиотика культуры и понятие текста. Ю. Ломан. История и типология русской культуры. С.-Пб.: Искусство-СПБ, 2002. С. 159. 
intermediary in the communication process. The text becomes an equal interlocutor with a sufficient degree of autonomy.

5. Communication between the text and the cultural context in which the text does not act as a message, but as its full participant - the source or recipient of information. Thus, «the text, on the one hand, becoming like a cultural macrocosm, becomes more significant than it and acquires the features of a cultural model. And on the other hand, it tends to carry out independent behavior, becoming like an autonomous personality» ${ }^{6}$.

As a special case that requires special consideration, Y. Lotman singles out the procedural level of communication between the text and the metatext. On the one hand, a particular private text can fulfill the role of a describing and commenting mechanism in relation to the context; on the other hand, it, in turn, can enter into decrypting and structuring relations with some metalanguage formation. The text appears to us not as an implementation of a message in any single language, but as a complex multi-level device that stores and transmits encoded information; that is able to process and transform received messages and generate new ones. The text becomes, according to the definition of Y. Lotman, «an information generator possessing the features of an intellectual personality» ${ }^{7}$.

Thus, at a general level, it can be found that the category of culture merges with the category of text, since both of these concepts - text and culture - are addressed to the leading principles of ordering human life. Based on the definition of Y. Lotman, we can conclude that since everything that enters into the culture begins to function as a text, there are three general properties between these two categories, namely: firstly, culture and text are delimited in time and in space; that means, they have a chronotopic side, since a chronotope is always an indicator of time and place; secondly, both culture and text strive for openness and limitlessness, for overcoming borders, which can be regarded as a desire for continuation, for reproduction at a new level; thirdly, both culture and text have stable structural features, thanks to which they can be recognized and reproduced.

Considering the Orthodox liturgical and singing tradition from these positions, one should once again emphasize the special functions and

6 Лотман Ю. Семиотика культуры и понятие текста. Ю. Ломан. История и типология русской культуры. С.-Пб.: Искусство-СПБ, 2002. С. 160-161.

7 Лотман Ю. Семиотика культуры и понятие текста. Ю. Ломан. История и типология русской культуры. С.-Пб.: Искусство-СПБ, 2002. С. 162. 
significance of the canon, which appears in it in two guises - as a principle and as a form. It is in the interaction of the canon as a principle and the canon as a form that the specificity of the liturgical ritual is expressed; therefore, with all the stylistic shifts - the visible stylistic freedom of chanting - the principle dominates the form. And that is why chanting always requires following the word, the prayer text.

In other words, the form can be interpreted as a concrete implementation of the essence of the thing, or rather, one of the specific realizations. This implementation does not change the essence of the thing, but rather the content of the thing, although it adds certain properties determined by the form to it, thereby forming the third thing. The essence of the thing is the content of the form, and the form itself is independent of the content. A feature of the relationship between form and content is that content can be implemented in various forms. Submission of form to the principle - as an expression of the canonical type of thinking in the "music of worship" - can be considered as the main basis for the integrity of liturgical singing.

\section{The canonical foundations of the Charter and (Typicon) functioning as a metatext of Orthodox worship}

Textology in its narrowest sense reveals its invariant - canonical text from several versions of the text, comments on its content and produces attribution (determines whether the text belongs to a particular era and to a particular author). Hermeneutics deals with the interpretation of the text; exegetics, in turn, deals with the interpretation of sacred texts. The skill of constructing a text, its structure and composition is studied by poetics. The text can be understood also extremely broadly, as it determines the semiotics and philosophy of the text. A kind of rival of the text is reality, or, as V. Rudnev writes, "the text turns out to be everything in the world and there is no room for reality... Reality is the text written by God, and the text is the reality created by man"8.

Continuing the thought of Rudnev, we can say that, representing the reality created by man, the text is a composition; being created by God, the text becomes identical with the principles of human being at its different levels and in various functional positions. Let us clarify again: the composition produced, composed by man - the composition itself is a text in the narrow sense of the word; being created by God,

${ }^{8}$ Руднев В. Словарь культуры ХХ века. М.: Аграф, 1997. С. 307-308. 
therefore, providing a single guiding creative principle for all human actions, is a text in its broad meaning. It is important to point out that, as the first textual discipline, hermeneutics, emerging from medieval theological works, sought to understand the text in its second, broader meaning, in reliance on canonical liturgical books. It is with the second meaning and purpose of the text, which is confirmed by the history of religious culture, that its canonical functions and the appearance of the canon are associated. That is why, Orthodox worship is based on the text as the principle of construction, functioning of various, relatively independent and completed textual components of the ordering (ritual), which, in particular, explains the stability of the boundaries, (especially external) of the church action.

This stability of the external borders is provided by the canon, which Pavel Florensky calls «the condensed mind of mankind» ${ }^{9}$. From this position, the canon provides the depth and accuracy of the expression of universal spiritual need; as Florensky wrote, «The canonical is the ecclesiastical, the ecclesiastical is the catholic, and the catholic is the universal» ${ }^{10}$. The canonical is understood as created within the tradition, within the life of the canon and under its direct influence; under this condition, the random is eliminated and the true is fixed. Thus, canons in the field of church hymns, as well as in the field of ancient icon painting, were created and crystallized over the centuries, while forming a special side of the canon, which reflected the relationship between the word and the melody.

A necessary condition for understanding the essence of the canonical in the church action is, according to Florensky, involvement in it. Only in this case the phenomenon of canon and canonical in church art becomes accessible for understanding and analysis.

The thoughts of M. Bakhtin about the processes of canonization and re-accentuation are also important: "Analysis ... encounters a special kind of difficulties, determined by the speed of the two processes of transformation, which affects every linguistic phenomenon: the process of canonization and the process of re-accentuation" ". Continuing these arguments, we note that any culture, any cultural phenomenon within its own limits is equally oriented towards canonization and rearrangement.

${ }^{9}$ Флоренский П. Иконостас. Христианство и культура. М.: Аст, 2001. С. 557.

${ }_{10}^{10}$ Флоренский П. Иконостас. Христианство и культура. М.: Аст, 2001. С. 562.

11 Бахтин М. М. Слово в романе. М. Бахтин. Boпросы литературы $и$ эстетики. Исследования разных лет. С. 226. 
Without literally using the concept of the canon, M. Bakhtin calls its two types - as two poles of the text. The first pole forms a system of signs associated with everything "repeated, reproduced, repeatable and reproducible" - that which is well-known and generally understood; the second pole - everything is individual, unique - and this is "its whole meaning, its purpose, that for which it was created"12. "This is in it," writes M. Bakhtin, "which is related to truth, truth, goodness, beauty, and history"13. With respect to this pole, everything that is repeated and reproduced is material and a means. Thus, the second "anti-canonical" pole of a literary text turns out to be a different kind of canonization, which affirms the legitimacy of the author's statement and leads to a clear definition of the boundaries of the individual style.

The most authoritative researcher in the field of post-structuralist theory of text is Roland Barth, whose activities ran in various fields; in particular, Barth proved to be a brilliant literary essayist, theorist, and critic. He formulated practically all the main provisions of textology, created a whole set of key expressions and phrases, or attached the previously used terms to their post-structuralist meaning (writing, signfighting, the death of the author, the effect of reality).

As already noted, the focus of R. Barth was a type of text analysis in which the researcher shifts the focus of his scientific interests from the problem of "composition" as a whole with a stable structure to the mobility of the text as a process of "structure". "Text analysis does not set itself the goal of describing the structure of a composition; the task is not to register a certain stable structure, but rather to produce a movable structure of the text (a structure that changes throughout history), to penetrate the semantic volume of the composition into the process of meaning. Text analysis does not seek to determine what determines the text, taken as a whole as a consequence of a specific reason; the goal is rather to see how the text explodes and dissipates in the intertextual space... Our task is: to try to catch and classify (by no means pretending to strictness) not all the meanings of the text (this would be impossible,

12 Самойленко А. Культурологическая концепция диалога М. Бахтина и методологические проблемы музыкознания. Культурологічна трансформація мистецької освіти та актуальні питання творчої діяльності музиканта в сучасній Украӥні. К., 1998. С. 21-37.

13 Бахтин М. Проблема содержания, материала и формы в словесном художественном творчестве. Бахтин М.М. Литературно - критические статьи. М., 1976. С. 475. 
since the text is infinitely open to infinity: not a single reader, not a single subject, not a single science is able to stop the movement of the text), but rather, those forms, those codes through which the emergence of the meanings of the text. We will follow the paths of meaning formation. We do not set ourselves the task of finding the only meaning, not even one of the possible meanings of the text... Our goal is to conceive, imagine, and experience the plurality of the text"14.

Unfortunately, this Barth's approach, which can be called semiographic in its broad sense, was not used in musicological studies. This led to the actual identification, merging of the concepts of text and composition, and, consequently, to the unlawful simplification of the phenomenon of the text itself. Also in philological studies, Barth's ideas did not receive sufficient development; meanwhile, M. Bakhtin and D. Likhachev come very close to them in their positions.

In the study "Musical text. Structure and properties", M. Aranovsky calls the determination of the relationship between the concepts of "text" and "composition" an important task. He even engages in a polemic with adherents of the theory of synonyms of the concepts "text" and "composition", indicating that it is possible to interpret the text in its narrow sense (in the meaning of "musical notation"): "There is no doubt that the text fulfills the function of invariant with respect to the set of its variant performing implementations. But if the text is only an invariant, then this is not the whole composition, but only its specific «part», or rather, the side, which is nothing more than a sound-rhythmic structure» ${ }^{15}$. The main difference between the «text» and the «composition» Aranovsky considers as «different ways of being of the same artifact» ${ }^{16}$. In his opinion, they can be defined as two opposing views on the same phenomenon, two methodologically different approaches from each other. We can talk about the existence of a composition only if it has already taken place, if it already exists «both physically and as imagination» ${ }^{17}$. Physical existence can be defined as the ability to perceive a composition as something material - a book,

${ }^{14}$ Барт Р. Избранные работы. Семиотика. Поэтика. М.: Прогресс, 1994. С. 541.

15 Арановский М. Музыкальный текст. Структура и свойства. - М. : Композитор, 1998. С. 23.

16 Арановский М. Музыкальный текст. Структура и свойства. - М. : Композитор, 1998. С. 24.

17 Арановский М. Музыкальный текст. Структура и свойства. - М. : Композитор, 1998. С. 24. 
sheet music or disk; the existence of a composition as a representation is manifested in its perception as a kind of convoluted simultanic image of the once perceived process of sounding (M. Aranovsky). According to $\mathrm{M}$. Aranovsky, we can talk about the text as if «what is still happening is proceeding in time» ${ }^{18}$. According to $\mathrm{M}$. Aranovsky, a composition can be called what is already there, that is, real, and the text is that which is still there, or maybe, that is, possible. The composition and the text are separated by time parameters, or rather, they are at different times: the composition, being already created, is in the past, and the text, being only created, is in the present and partly in the future. "The composition unfolds as text - the text collapses as a composition» ${ }^{19}$. In this case, the composition appears as a predominantly spatial phenomenon, and the text - as primarily temporary. However, R. Barth, pointing out the difference between the composition and the text, writes that not the text is a consequence of the composition, but, on the contrary, «the composition is a train of the imaginary, stretching for the text» ${ }^{20}$. M. Aranovsky agrees with this statement, clarifying that this thesis can be considered true if we take into account the natural course of events in which the creation of the text is really preceded by the emergence of the composition as an integral phenomenon. Therefore, in this case, the distinction between the text and the composition is a consequence of the position taken by the observer. In other words, at one angle of view, what we observe is seen to be accomplished, and then it is a composition; at another, we observe the process, and then it appears as being done, and then it turns out to be a time-expanding text. M. Aranovsky proposes to call this phenomenon a projective whole, which precedes the creation of the text of the composition, but at the same time remains the ideal that the artist aspires to during the creation of the opus and which directs it as an ideal whole. Although this is not a composition, it can be called its prototype, which should unfold in the text. In the liturgical and singing tradition, this prototype, the given source for creating a single text of liturgical action, is the Typicon in combination with church tradition.

18 Арановский М. Музыкальный текст. Структура и свойства. - М. : Композитор, 1998. С. 24.

19 Арановский М. Музыкальный текст. Структура и свойства. - М. : Композитор, 1998. С. 24-25

20 Барт Р. От произведения к тексту. Ролан Барт. Избранные работы. Семиотика. Поэтика. М., 1989. С. 415. 
Thus, the text appears as that side, that aspect of the composition in which it appears in its temporal hypostasis, while the composition, in turn, is the result of the implementation of the temporal side. In other words, a text is always a process, and a composition is a consequence of a reducing and generalizing synthesis.

\section{CONCLUSIONS}

Being formed historically, the liturgical text is historically independent, constant structural, including spatial and temporal connections of three main levels of the Orthodox tradition: action ordinance; pronouncing the liturgical text; finally, the musical and singing intonation of the verbal text when pronouncing it. That is, it turns out to be simultanic unity of the ritual and pragmatic, prayer and musical aspects.

The liturgical word creates its own symbolic series, requiring special conditions of understanding. It can be considered sufficiently recognized that the word in the Orthodox ordering of passage is the focus, the central semantic element of the liturgical text. However, being sounding at its core, the Orthodox prayer text requires expression and completion in its musical side. It is the manner of musical reading (reading and singing) of the musical text is the most striking identification mark of it as a cult, religious. The singing voice of the prayer (liturgical) text forms the third, final, and, at the same time, formative level of the musical text; it is especially important that this level has been evaluated since ancient times by its emotionally expressive function, by its psychological significance. It is it that becomes not only important, but also indicative of the historical evolution of the liturgical text. The compilation of the chronology of Orthodox worship, the determination of the periodization of the history of the Orthodox tradition, as a rule, is based on the study of the evolution of the singing side of the liturgical text.

The Typicon phenomenon takes on the metatext of the Orthodox tradition, which determines the formation of genre prerequisites, genre opportunities and stylistic conditions for the development of the liturgical cycle. It allows to emphasize the special functions and significance of the Orthodox liturgical canon ${ }^{21}$, which determines the

21 Осадчая С. Явление и понятие канона как основа православной богослужебно-певческой традиции: от канонической формы к «духу творчества». Музичне мистецтво $і$ культура. Науковий вісник. Одеса: Астропринт, 2016. Вип. 22. 
formation of genre prerequisites, genre opportunities and stylistic conditions for the development of the liturgical cycle. It allows to emphasize the special functions and significance of the Orthodox liturgical canon, which appears in the singing tradition in two guises - as a principle and as a form. It is precisely in the interaction of the canon as a principle and the canon as a form that the specificity of the liturgical ritual is expressed: with all the stylistic shifts - the visible stylistic freedom of chanting - the principle dominates the form, and that is why chanting always requires following the word, the prayer text. Submission of the form to the principle, as an expression of the canonical type of thinking in music, can be considered as the main basis for the integrity of liturgical singing.

Thanks to the canon - from the side of the canon phenomenon - the interaction of the text as a principle and the text as a form in the organization of the singing material of the Orthodox worship is obvious; the expression of the complex interaction of test capabilities, genre and style conditions, canonical indicators of liturgical singing is cyclical. Cyclicity, saturated with canonicity, reflecting the nature of the text, also appears in two meanings - as a principle and as a form.

Cyclicity is a general principle of system formation in the Orthodox tradition, which determines, on the one hand, the stability of external borders, and on the other, is the main communicative property of this tradition. Fixation and streamlining of the hymnographic component functioning as the main structural component, as well as cyclicity - as a factor in the dynamics of tradition - is implemented in the Charter (Typicon), along with it - and in statutory practice, which finds its fixation in the Church Tradition.

Liturgical singing, as part of the liturgical texture itself, is strictly subject to certain rules of the Church Charter. Moreover, the statutory instructions relate not only to the order (sequence) of chant texts in the process of worship, but also to all aspects of church singing, namely: distribution of chants according to the nature of their text and melody, regulation of the breadth of melodies, speed of performance and strength (volume) of sound, personnel performers, control means, and many others. Liturgical Charter (Typicon), regulating the order of liturgical actions, readings and singing, in some cases indicates combinations of order, voices in which one or another chant needs to be performed, and also often indicates a melodic pattern for singing (similar instructions); it indicates in the most general terms the nature of the performance of famous chants or entire parts of worship. In daily worship, cyclic time 
manifests itself in a particularly structured form, since, firstly, the constant regularity of masses, their constant flow day after day, reveals the autonomy of the life of the Church, its independence from external material conditions; secondly, the liturgy itself is full of cult repetitions, which also "reproduces the circulation of the subtle world" (A. Dugin) ${ }^{22}$. Thirdly, the liturgical actions themselves performed by the clergy (this applies equally to the readable and the singing sides) are associated with movements that take on a "rotational" character.

Preserving the features of the primary genre system, the Liturgy, the typical chants included in it, and other cyclically united texts of worship having a singing form make it possible to understand that the appearance of the genre, the category of the genre, does not boil down to only artistic, especially musical purpose. In the case when the principle of functioning of the genre and the genre form express the purposefulness of the cultural tradition, taken in the unity of all its parties, the concept of the genre expands to the limits of a significant indicator, a semantic substitute for this tradition, that is, it turns out to be mostly pragmatically oriented.

Thus, the musical and singing system of Orthodox worship, considered as an independent phenomenon, accumulates and expresses its most essential and, at the same time, effective antinomy - the antinomy of the canon as a principle and the canon as a form. This antinomy is realized and peculiarly resolved in the interaction of the genre and style aspects of the singing system. The same interaction (genre and style) should be considered, as shown by the analysis of historical church experience and the current state of church Orthodox practice, based on the interaction of everyday and author's trends in church singing.

\section{SUMMARY}

The singing side of the Orthodox ordering in its semantic vocation expresses its attitude to the ongoing ritual action and the pronounced ritual text; we can say that it captures the evolutionary trends of the canonical forms of Orthodox worship (the canon as a form), while at the same time determining the limitation of these trends, that is, the limits of possible stylistic modifications.

22 Дугин А. Метафизика благой вести (православный эзотеризм). М.: Арктогея, 1995. 
The sequence and correlation of the structural layers of the Charter, which also become the main cyclic indicators, the substantive and formal circles of the Typicon, correspond to the historical sequence - the historical order of these layers appearance - circles. Thus, the significance of the historical context, including the dynamics of the historical process, in the formation of the Orthodox singing system from the side of ordinance, that is, from the action of the canon as a principle, is revealed.

However, the historical dynamics of the canonical statutory requirements can be discussed until the XI-XII centuries, when it is finalized that symbolic semiotic system of the functioning of the Orthodox Church, which becomes the genre foundation of the Orthodox singing system, takes on its final form.

Thus, the musical and singing system of Orthodox worship accumulates and expresses its most essential and, at the same time, effective antinomy - the antinomy of the canon as a principle and the canon as a form; this antinomy is realized and resolved in a peculiar way in the interaction of the genre and style aspects of the singing system. This same interaction (genre and style) should be considered, as analysis of both the historical course of church experience and the current state of church Orthodox practice shows, based on the interaction of everyday and authorial trends in church singing. The interaction of these trends forms the stylistic content of the Orthodox singing system with its leading features and characteristics, and also allows us to explain it as a musical and historical phenomenon.

\section{REFERENCES}

1. Арановский М. Музыкальный текст. Структура и свойства. М.: Композитор, 1998. 345 с.

2. Барт Р. Избранные работы. Семиотика. Поэтика. М.: Прогресс, 1994. 615 с.

3. Барт Р. От произведения к тексту. Ролан Барт. Избранные работьл. Семиотика. Поэтика. М., 1989. С. 415.

4. Бахтин М. М. Слово в романе. М. Бахтин. Bопросы литературы и эстетики. Исследования разных лет. С. 72-234.

5. Бахтин М. Проблема содержания, материала и формы в словесном художественном творчестве. М. Бахтин. Bonpocbl литературы и эстетики. Исследования разных лет. М.: Художественная литература, 1975. С. 6-72. 
6. Гарднер И.А. Богослужебное пение русской православной церкви. Сущность. Система. История. Т. 1. Сергиев Посад: Московская духовная академия, 1998. 592 с.

7. Дугин А. Метафизика благой вести (православный эзотеризм). М.: Арктогея, 1995. 264 с.

8. Лихачев Д. С. Текстология (на материале русской литературы X-XVII вв.). С-Пб.: Алетейя, 2001. 759 с.

9. Лотман Ю. Семиотика культуры и понятие текста. Ю. Ломан. История и типология русской культуры. С.-Пб.: Искусство-СПБ, 2002. C. $158-162$.

10.Мартынов В. История богослужебного пения. Учебное пособие. М.: РИО Федеральных архивов; Русские огни, 1994. 240 с.

11. Матвеев Н. В. Хоровое пение. История русского церковного пения. Электросталь: Издательство братства во имя святого князя Александра Невского, 1998. 287 с.

12.Осадчая С. Явление и понятие канона как основа православной богослужебно-певческой традиции: от канонической формы к «духу творчества». Музичне мистецтво $i$ культура. Науковий вісник. Одеса: Астропринт, 2016. Вип. 22. С. 217-225.

13.Руднев В. Словарь культуры ХХ века. М.: Аграф, 1997. 384 с.

14.Самойленко А. Культурологическая концепция диалога М. Бахтина и методологические проблемы музыкознания. Культурологічна трансформачія мистецької освіти та актуальні питання творчої діяльності музиканта в сучасній Україні. К., 1998. C. 21-37.

15.Флоренский П. Иконостас. Христианство и культура. М.: Аст, 2001. С. 521-627.

\section{Information about the author:} Osadcha S. V., Doctor of Arts, Professor at the Department of Music History and Musical Ethnograph, Odessa National A. V. Nezhdanova Academy of Music 63, Novoselskogo str., Odessa, 65023, Ukraine 


\section{AUTOPOIESIS AS AN IMMANENT CREATIVE PROCESS OF THE ARTIST AND MUSICIAN}

\section{Ohanezova-Hryhorenko O.}

\section{INTRODUCTION}

"We seek to analyze and understand the fundamental ways of thinking, comprehending, representing, imagining and reproducing in language, myth, art, religion, and even in science. We are no longer interested in individual art works, products of religious or mythological thinking; we are interested in those motor forces, the mental activity that is needed to create them"1. This statement of the philosopher and culturologist E. Cassirer emphasizes the main problem of modern art analysis, which, in our opinion, acquires a new quality precisely because it brings to the forefront of research the immanent component of the creative process. Modern art history analysis explains the origin and laws of the immanent creative process through the modern paradigms of the scientific worldview proposed by the development of the exact sciences, as well as through the use of natural history trends in the analysis of phenomena that are traditionally in the field of view of the humanities.

Taking into account the above-mentioned, we suggest exploring the professional personality of the artist and musician in line with the concept of autopoiesis of living systems and explaining the specifics of immanent creative processes, self-organization of the system through music and musical experiences.

\section{Phenomenology of autopoiesis of the living system}

Autopoiesis (from the Greek - myself + production, construction, creativity) - is a way of existence and development of complex structures (formations), allowing them to constantly produce and finish building themselves. The term was introduced by Chilean scientists Francisco Varela and Umberto Maturana in 1973 to reveal the essence of

${ }^{1}$ Кассирер Э. Лекции по философии и культуре // Культурология. ХХ век : антология / гл. ред. и сост. серии С.Я. Левит. М.: Юрист, 1995. 704 с. (Лики культуры). С. 147. 
living systems: their cyclical organization, autonomy, self-building and preservation of their identity in a changing environment ${ }^{2}$. Autopoiesis is self-organization of a living system.

U. Maturana and F. Varela sought to highlight the key feature of a living system. In their opinion, the essence of life is not the ability to reproduce, self-reproduce, as it is commonly believed, but the ability of a living system to maintain its identity. An autopoiesis system is built on the principle of self-attribution, a cyclical organization, it produces itself from itself. The spatial symbol of autopoiesis can be called a loop, as the quintessence of the process of returning to oneself.

As the most characteristic qualities of living systems, F. Varela and U. Maturana singled out the ability to self-production and sustainable development in their environment. Accordingly, the authors put forward the principle of operational isolation, autopoiesis continuity and spatial limitation $^{3}$. But, in the opinion of I. E. Moskalev, we are talking about a special kind of isolation, allowing the system to interact with the outside world and continuous self-development at the same time. On the one hand, something makes the system remain operationally closed with respect to the external environment (that is, maintain the basic life cycles and reproduce itself unchanged), and on the other hand, actively interact with the environment and use its challenges as a material and basis for self-organization already at a more advanced level. Thus, the ideas of cyclicality and circular causality in the context of autopoiesis acquired a new sound - as a description of sustainability, development and selfproduction at the same time 4 .

The function of autopoiesis is, firstly, the ability to constantly reproduce itself, and secondly, to maintain its autonomy with respect to the environment. Moreover, it is important that self-reproduction provides the active use by the system of external excitations as the lifegiving material of the process.

${ }^{2}$ Князева Е.Н., Курдюмов С.П. Основания синергетики. Синергетическое мировидение. Изд. 3-е, доп. М. : Книжный дом «Либроком», 2010. 256 с. (Синергетика: от прошлого к будущему). С. 18.

${ }^{3}$ Maturana H.R., Varela F.J. Autopoiesis and Cognition. The Realization of the Living. Dordrecht : D. Reidel, 1980.

${ }^{4}$ Москалев И. Е. Концепция автопоэзиса в современном научном познании [Электронный ресурс] : дис. ... канд. философ. наук: 09.00.08 . Москва, 2002. 141 c. URL : www.Synergetic.ru : 
The autopoiesis system owns a certain set of vital activity patterns, maintains its identity; it self-develops, self-reproduces, and remains resistant to the influence of external factors. This system is aimed at its own continuous updating and maintaining the integrity of its structure, therefore its sole purpose is to recreate itself. Thus, the most important characteristic of living systems is the ability to change its structure under the influence of external factors, but to remain the same system without losing organizational features - that means that the ability of living systems to constantly change is a condition for them to maintain their integrity and uniqueness 5 .

In this context, the main characteristic of living systems - the ability to self-organize - is clear. It must be emphasized that any processes in a living system are aimed only at autopoiesis. If the scheme is not implemented, the system is destroyed. A. A. Aredakov summarizes: "The concept of autopoiesis considers living as a system that exists in the eternal flow of substitutions of the material structure with the invariable form of the network - the invariability of the system pattern. The system pattern determines the cycles of its life, an algorithm of operations that allows it to reproduce itself» ${ }^{6}$.

The core characteristic of the living is the indissoluble connection of the system with the environment - E. N. Knyazeva and S. P. Kurdyumov explain it as a process occurring due to the structural interaction of the system and the outside world - their dynamic unity: "A complex system capable of self-organization is at the same time separated from the world and connected with it. Its boundary is similar to the membrane, which is the connection / separation boundary. The membrane allows the system to be open to the world, to take the necessary substances and information from the environment, and to be separate from it, in all its transformations and transformations, to maintain its integrity, to preserve its identity"7.

5 Ласицкая Э.В. Концепция автопоэзиса: бытие, познание, деятельность // Известия Саратовского университета. Серия: Философия. Психология. Педагогика. 2011. Т. 2, вып. 4. С. 14-16.

6 Аредаков А.А. Сознание в онтологиях антропного принципа // Вопросы философии. 2008. № 1. С. 45-50. С. 47.

7 Князева Е.Н., Курдюмов С.П. Основания синергетики. Синергетическое мировидение. Изд. 3-е, доп. М. : Книжный дом «Либроком», 2010. 256 с. (Синергетика: от прошлого к будущему). С. 216. 
In other words, the concept of autopoiesis considers the structural conjugation of the system and its environment as a continuous recurrent process of mutual disturbances between the system and the environment, compatible with the preservation of self-organization within a living system. In this context, it is important to note that the environment only initiates structural changes to the system, but does not specify them. Due to structural conjugation and operational isolation, the nervous system of a living organism works exclusively with internal correlations, and only they determine all the conditions of a living organism as a whole. The structural conjugation of the autopoiesis system determines the area of interaction into which it can enter. F. Varela and U. Maturana called this region as the cognitive region.

Taking this into account, we turn back to the semantic position in the concept of autopoiesis, which considers the issues of cognition from the point of view of the biological approach.

U. Maturana and F. Varela insist that the world is not given to be understood in its finished form: it is constructed by the cognitive system in the process of life. And the biological characteristics of a living organism determine the way of life - this position is fundamental. Scientists note: "All cognitive experience, including the cognitive on a personal level, is rooted in its biological structure» ${ }^{8}$.

Relying on the assertion that cognition has biological roots, and its results are determined by the physiology of the body, we affirm that the autopoiesis system "artist and musician" selects such an area of cognition - a type of communication that is a priori interesting to it, that is, defined by natural psychophysical inclinations. We find confirmation of our conclusions in the words of E. V. Lasitskaya: "The living system is in contact only with that part of its environment, which is the cognitive niche of this organism. The cognitive area in which it exists is determined by the autopoiesis of the system, so the area of cognition and living coincides» ${ }^{9}$. This conclusion is decisive in understanding the mechanism of choice by the system of its environment of life and development - its professional path.

8 Варела Ф., Матурана У. Древо познания. Биологические корни человеческого познания / пер. с англ. Ю.А. Данилова. М. : Прогресс-Традиция, 2001. 224 c. C. 14.

9 Ласицкая Э.В. Концепция автопоэзиса: бытие, познание, деятельность // Известия Саратовского университета. Серия: Философия. Психология. Педагогика. 2011. Т. 2, вып. 4. С. 15. 
The authors of the concept evaluate any interaction between the system and the environment as a cognitive act of the system. On the one hand, the environment has a resource that it uses to survive, self-support and self-creation of the body. On the other hand, the environment can pose a threat to the life of an organism in the form of its autonomy violation. Thus, the interaction of the system and the environment occurs as a fixation of challenges and the response of a living organism in a certain way, which, in fact, is a cognitive act.

The concept of autopoiesis develops within the framework of the evolutionary-synergetic paradigm, and this suggests that "the knower is rooted in the knowable, is one with him. He creates his world on the basis of physiological and cognitive capabilities, so knowledge takes on a "human-sized" character: in post-non-classical science, the world is given through man and his psychology"10. It is not for nothing that the visual image of the authors of the autopoiesis concept is Escher's drawing, depicting hands which are painting themselves. Thus, cognition of the environment (interaction with the environment) is carried out as a system of autopoiesis. According to E. N. Knyazeva, just such a view allows you to remove the «rigid subjective and objective construction of knowledge, based on the distance of the observer from the world ${ }^{11}$.

One of the most significant discoveries of recent times in the intellectual sphere is the discovery of an observer. The description of a living system is possible only from the point of view of a living system, which is the observer himself. In the concept of autopoiesis, the observer (the man himself) is a complex self-developing system that has the ability not only to self-production and renewal, but also selfreferentiality, working with his own descriptions as independent entities. There is no external reference; it means, there is no instance external to the system that can be consulted for a description of the system. A system is a self-describing structure. In other words, describing the technology of the creative process of the artist and musician, we simultaneously describe both the connections of the system with the outside world and the way of life of the system itself.

10 Ласицкая Э.В. Концепция автопоэзиса: бытие, познание, деятельность // Известия Саратовского университета. Серия: Философия. Психология. Педагогика. 2011. Т. 2, вып. 4. С. 16.

11 Князева Е.Н. Кибернетические истоки конструктивистской эпистемологии // Когнитивный подход : монография / отв. ред. В.А. Лекторский. М. : Канон+ ; РООИ «Реабилитация», 2008. 464 с. С. 261. 
The ability of the system to describe, analyze itself allows us to draw the following conclusion: the autopoiesis system proceeds from the properties of self-consciousness, which allows us to talk about the process of professional creativity as the action of the system in relation to the external environment in connection with the actions of the system in relation to itself, to its structure ${ }^{12}$.

Based on the above-mentioned, we can conclude that living systems are self-learning systems. Identifying the area of interaction - vital activity with the cognitive area, cognitive activity, F. Varela and U. Maturana come to the conclusion that «living systems are cognitive systems, and life as a process is a process of cognition $\rangle^{13}$. Talking about knowledge, F. Varela and U. Maturana understand «effective behavior in a given context» ${ }^{14}$. It is this area of adequate interaction between the system and the environment that allows to have autopoiesis in a living system.

The autopoiesis system does not display, but constructs reality, creates its own world, "cuts out" the layer of the world corresponding to its search activity and cognitive capabilities ${ }^{15}$. Thus, the structure of the autopoiesis system «artist and musician» is a reflection of its biological orientation in the choice of knowledge and activity.

The main mechanism of interaction between the system and the environment is communication. The German scientist N. Luman believes that communication is the main mechanism not only for interfacing the system and the environment, but also the mechanism by which the system distinguishes itself from the environment and also defines communication as an element and operation of the system ${ }^{16}$. In other words, the author considers communication as a specific language system that provides a structural union of internal processes of self-

12 Князева Е.Н., Курдюмов С.П. Основания синергетики. Синергетическое мировидение. Изд. 3-е, доп. М. : Книжный дом «Либроком», 2010. 256 с. (Синергетика: от прошлого к будущему).

${ }_{13}^{13}$ Maturana H.R. Biologieder Realitaet. F/M : Suhrkamp, 1998. P. 194.

14 Варела Ф., Матурана У. Древо познания. Биологические корни человеческого познания / пер. с англ. Ю.А. Данилова. М. : Прогресс-Традиция, 2001. 224 c. C. 153.

15 Князева Е.Н. Кибернетические истоки конструктивистской эпистемологии // Когнитивный подход : монография / отв. ред. В.А. Лекторский. М. : Канон+ ; РООИ «Реабилитация», 2008. 464 с. С. 267.

16 Луман Н. Социальные системы / пер. с нем. И.Д. Газиева; под ред. Н.А. Головина. СПб. : Наука, 2007. 648 с. 
organization in the system and the environment. Thus, relying on $\mathrm{N}$. Luman's understanding of the connection between communication and consciousness ${ }^{17}$, we note that the type of communication determines the mechanisms of its awareness and vice versa. This thesis is very important in understanding the conditions for the emergence of a professional process in the «artist and musician» system, which is carried out only if there is a certain natural task of the system - musical talent.

\section{Autopoiesis as a mechanism of the creative process}

Regarding the work of the artist and musician, communication - a way of communicating with the environment - is professional language - sound (timbral) impact. At the same time, the feeling of tonal changes in sound is a prerequisite for the implementation of the process of autopoiesis in the «artist and musician» system.

Autopoiesis as a mechanism of «creation», as a process of life and self-construction, best reflects the specifics of the artist's creative personality. M. A. Chekhov called this process «the creation of life». All the feelings, sensations, thoughts and actions of the artist are consciously and unconsciously aimed at creativity - at creating from his real personality a fictional musical image. In this process, not only a new living substance is born, but also the artist's personality is "created". In his book "The Way of the Actor" M. A. Chekhov regarded the artist's creativity as self-creation - the creation of his personality, the genesis of which consists of the possibility of "creativity within himself" for "creativity outside of himself"18.

We believe that any performing talent is an autopoiesis system, which assumes that the forces, abilities, specific qualities of intelligence, psychophysical properties of the body work in a mode of self-creation and self-improvement.

M. A. Chekhov insisted that performing art is a bizarre living fabric that includes a sense of the real world and sensory perception of this world in their unity, considered the highest point of stage creativity inspiration - as the ability of an artist to give his body to the flow of the creative process - an unconscious state, prepared and at the same time

17 Луман Н. Социальные системы / пер. с нем. И.Д. Газиева; под ред. Н.А. Головина. СПб. : Наука, 2007. 648 с.

18 Чехов М.А. Путь актера. М. : АСТ : Транзиткнига, 2003. 554, [6] с. (Мемуары). С. 62. 
controlled by conscious regulation. The most subtle connection between the conscious and the unconscious in the work of the creative apparatus is expressed, in our opinion, by the concept of "autopoiesis". The emphasis should be placed on the fact that the source of the unconscious for the creative person is not only "impersonal", but also the unconscious - the in-depth and produced by their sphere of collective unconscious.

In this context, it is appropriate to recall the concept of K.-G. Jung, who, unlike Z. Freud, did not consider psychology and imagery of thinking as a reflection of exclusively biological intentions. Images, in the understanding of K.-G. Jung, play the same important role as instincts, because to a large extent they carry archetypal elements. M. Y. Severinova also notes that it is a mistake to rigidly separate the personal and collective unconscious, because in order for the archetype as a «frame idea» to be able to «build up the flesh», a certain experience of life is necessary ${ }^{19}$.

The artist translates the meaning of primitives in a language that is understandable to modern man. The artist with the help of his living organism and the properties of his personality embodies the language of the unconscious on stage. According to M. Y. Severinova, artistic creativity, as a way of transforming psychic phenomena into phenomena of cultural life, through the unconscious turns to archetypal prototypes, leading them to turn into conscious values. Therefore, the archetypal core of the personality is not only the basis of creativity, but also its necessary component. Thus, according to the scientist, the creative process largely depends on the degree of immersion in the unconscious ${ }^{20}$.

A. F. Kosarev develops a similar idea: the scientist insists that in immersion to the unconscious we have the opportunity to observe the idea «not in the form of an abstract concept - this is the prerogative of

${ }^{19}$ Северинова М.Ю. Архетипи в культурі у проекції на творчість сучасних українських композиторів : дис. ... д-ра мистецтвозн. : 26.00.01 / НМАУ ім. П.І. Чайковського. Київ, 2013. 415 с. С. 86.

${ }^{20}$ Северинова М.Ю. Архетипи в культурі у проекції на творчість сучасних українських композиторів : дис. ... д-ра мистецтвозн. : 26.00.01 / НМАУ ім. П.І. Чайковського. Київ, 2013. 415 с. С. 90. 
logical thinking, but in the form of sensory - such that is seen, such that is heard - an image (image-meaning)» ${ }^{21}$.

In the context of research issues, we rely on the positions of scientists in order to accentuate understanding of autopoiesis as a process of conscious and unconscious informatively-sensual exchange, which is the basis and at the same time the mechanism of the creative process of the artist and musician, because, according to a famous psychologist, a researcher of specific features of a creative person N. F. Rozhdestvenskaya, «in the creative mind, knowledge, experience and attitude are combined into one» ${ }^{22}$.

As you know, a person has the opportunity to gain knowledge about the world not only through his practical experience, but also through spiritual experience, from himself, from his consciousness and subconscious. It is this phenomenon that largely explains the artist's ability to experience on stage and convey to the viewer those emotions that were not experienced in real life. On the one hand, this is the merit of fantasy as the primary creative ability, and on the other, this is the genetic stock of the unconscious experienced by man in the broadest sense of the word. After all, as A. G. Vasadze claimed, the unconscious sphere of the psyche «is a sphere belonging and entering into the structure of the artist's personality» ${ }^{23}$. Art is literally permeated with the activity of the unconscious at all levels, from the most elementary to the highest ${ }^{24}$.

Given the general specificity of the creative process of the artist and musician, the concept of autopoiesis can be used to understand the processes of consciousness, since it indicates the unity of cognitive and creative functions. In this sense, we understand autopoiesis as a certain form of consciousness that allows the system to evolve to a complex

21 Косарев А.Ф. Философия мифа : Мифология и её эвристическая значимость : учеб. пособие для вузов. М. : ПЕР СЭ ; СПб. : Университетская книга, 2000. 304 с. С. 84.

22 Рождественская Н.Ф. Психология художественного творчества: учеб. пособие. СПб. : Языковой центр филол.ун-та Санкт-Петерб.гос. ун-та, 1995. 270 c. C. 27.

${ }^{23}$ Васадзе А.Г. Проблема художественного чувства. Тбилиси : Мецниереба, 1978. 174 c. С. 95.

24 Бессознательное: Природа. Функции. Методы Исследования : в 4 т. Тбилиси : Мецниереба, 1978. Т. 2. 688 с. С. 478. 
cognitive system that owns a developed consciousness ${ }^{25}$. According to E. N. Knyazeva "the auto-poetry of the consciousness work is its continuous self-production, its maintenance of its identity through its constant search and its formation. In autopoiesis there is always not only the preservation of the state, but also its overcoming, updating, ${ }^{26}$. Thus, we understand the autopoiesis of the artist and musician as a creative state of his consciousness, which implies the existence of a vector for self-construction, invention and construction, achievement of goals and building integrity ${ }^{27}$. F. Varela's thought is important in this context: the scientist emphasizes that in its essence, cognition (in our context, the creative process) is autopoiesis - "it is aimed at finding what is missing and filling out the missing cognitive agent from the point of view"28. Thus, autopoiesis of consciousness can be interpreted as the ability of the system to maintain its autonomy with respect to the external environment, depending on the level of self-organization, a quality that allows the system to maintain its identity and individuality even in conflict with the environment.

So, we understand the autopoiesis of the consciousness work of the artist and musician as a way of self-organization of an autopoiesis system that allows cognitive and creative functions of consciousness to manifest itself, it is such a quality of co-evolution of the artist's consciousness and environmental challenges that enables the system to reach an attractor, an acme, a psychological indicator of which for a creative person is experiencing catharsis.

Summing up, we emphasize that the concept of autopoiesis allows to describe and analyze a living system - the artist and musician in terms of a professional creative algorithm. Also, the concept of autopoiesis opens up possibilities for analyzing the work of the psychophysical apparatus of the artist and musician in a cognitive aspect - in terms of organizing a

25 Ласицкая Э.В. Концепция автопоэзиса: бытие, познание, деятельность // Известия Саратовского университета. Серия: Философия. Психология. Педагогика. 2011. Т. 2, вып. 4. С. 14.

${ }^{26}$ Князева Е.Н., Курдюмов С.П. Основания синергетики. Синергетическое мировидение. Изд. 3-е, доп. М. : Книжный дом «Либроком», 2010. 256 с. (Синергетика: от прошлого к будущему). С. 217.

${ }^{27}$ Князева Е.Н., Курдюмов С.П. Основания синергетики. Синергетическое мировидение. Изд. 3-е, доп. М. : Книжный дом «Либроком», 2010. 256 с. (Синергетика: от прошлого к будущему). С. 216-217.

${ }^{28}$ Varela F.J. Patterns of Life: Intertwining Identity and Cognition // Brain and Cognition. 1997. Vol. 34. P. 85. 
professional algorithm and establishing the specifics of natural psychic and psychological characteristics that help to establish certain galaxies of abilities during the period of professionalization. Such an analysis (introspection) opens up opportunities in understanding the strengths and weaknesses of one's talent, in building the right career growth strategy, respectively, in the possible achievement of acme.

\section{Creative dominant - a parameter of the autopoiesis system order}

In other words, self-organization (autopoiesis) acts as a constructive, ordering mechanism for the evolution of the personality of the artist and musician as a professional. The ability to self-organize (self-regulation) is one of the most important indicators of professional suitability.

A living organism is that self-organizing system that constantly goes into a critical mode by its very nature, as a result of its inherent internal tendencies of evolution. The critical states of such systems do not require fine tuning of external control parameters and, in fact, have the property of self-support ${ }^{29}$. We are interested in the following: what is the source of such self-support?

Since we consider the psychophysical apparatus of the artist and musician as a self-organizing system, it is important to highlight the order parameter of this system. According to the synergistic concept, the concept of an order parameter helps to understand and describe the principles of system behavior, its hierarchical levels, main and secondary segments, and the nature of their interaction. The concept of "order parameter" was introduced by the German scientist G. Haken as a factor determining the degree and quality of influence on a system at a dynamic level, a factor to which the behavior of all elements of the system is subordinate $^{30}$.

The most informative element of the self-organizing system «artist and musician» is, in our opinion, the creative dominant - the constant natural need for creative activity inherent in its psychophysical organization. As M. P. Blinova writes, "For a productive creative

${ }^{29}$ Евин И.А. Искусство и синергетика. М. : Едиториал УРСС, 2004. 164 с. C. 12 .

${ }^{30}$ Князева Е.Н., Курдюмов С.П. Основания синергетики. Синергетическое мировидение. Изд. 3-е, доп. М. : Книжный дом «Либроком», 2010. 256 с. (Синергетика: от прошлого к будущему). С. 211. 
process, long-term support for optimal arousal, that is, the presence of the so-called dominant» ${ }^{31}$.

Dominant (from lat. dominaus - ruling, dominant) - determines the direction of behavior and thinking. According to A. A. Ukhtomsky, who proposed the term and developed the doctrine of the dominant, the dominant is the main emotional and psychological need of the individual; it is not only the normal working principle of singing centers, but it also plays a significant role in the process of neoplasms of reactions to the environment. According to the scientist, it is the dominant that ensures the organism's adaptation to the environment, its survival, and, if necessary, the transformative effect on the environment. The dominant increases the power of the system itself and becomes the material basis for its long-term adaptation to the challenges of the external environment ${ }^{32}$.

I. A. Evin considers principle of dominant by A. A. Ukhtomsky for nervous activity similar to the principle of submission in the processes of self-organization, where the creative dominant itself performs the function of an order parameter. In his opinion, thanks to the creative dominant a universal and same description of any creative system can be realized.

Confirmation of the importance of creative dominant for the maintenance and self-organization of the artist as an autopoiesis system is found in Y. M. Shor, who presents the artist as the most complicated synthesis of psychophysical and social, on the border of which the specificity of his personality arises: "An artist is distinguished from a non-artist by the main dominant focus on aesthetic activity, on the creation of artistic images, on the transformation of his mental world into an aesthetic world. As soon as this activity begins, a transformation takes place, mental processes are grouped around a super-task, begin to work as moments of higher integrity, become elements of an artistic system» ${ }^{33}$. It is the creative dominant that makes us consider all external events and

31 Блинова М.П. Музыкальное творчество и закономерности высшей нервной деятельности / Ленингр. гос. ин-т театра, музыки и кинематографии. Л. : Музыка, Ленингр. отд-е, 1974. 142 с. С. 20.

32 Ухтомский А.А. Доминанта. СПб. : Питер, 2002. 448 с. (Серия : «Психология - классика»). С.59.

33 Диагностика и развитие актерской одаренности : сб. науч. тр. / Ленинградский государственный институт театра, музыки и кинематографии им. Н.К. Черкасова. Л., 1986.155 с. С. 8. 
changes in the internal states of the artist and musician through the prism of their usefulness for the creative process. Experienced artists know that they collect any event of life, any act, any reaction of others, and, most importantly, the reaction of their psychophysical apparatus to this, into an "emotional box". This is the material from which artists "breathe life" into fictional musical images through reservoirs of emotional memory. The timbre palette of the image, the plastic features of the performance, etc. manifestations - all this material is born of the imagination of the creator, feeding on the experience of life. This feature of the artistic personality nature, in our opinion, is eloquently reflected in the concept of dominant: "Dominant is a disturbed, loosened place of the nervous system, a kind of "shooting", to which all necessary and unnecessary sticks, from which then the selection of what is enriched experience is done",34.

It should be noted that the artist, thanks to the power of creative dominant, is able to withstand any tests by the outside world - both positive and negative. For example, if the field of life of the autopoiesis system "artist and musician" is a professional musical composition that meets the needs of a creative dominant, then lack of money, for example, will not force it to change its occupation. The response to the challenge is rather not a change of profession, but more intense professional work and / or more aggressive behavior in the corporate environment. Thus, one can speak of creative dominant as a vital determining condition for the evolution of the autopoiesis system.

It should also be noted that the creative dominant is capable of changing its strength depending on objective circumstances - the possibility or impossibility of realizing a person in a given profession, in a given place, at given time; as well as subjective circumstances accentuation of the personality, level of talent, some of the innate mental qualities of the psychophysical organization, which either help in overcoming environmental challenges or not. But it is always the creative dominant that is capable of blocking by force and significance all other dominants.

In other words, we can talk about the creative dominant as an internal spring, a kind of "energy block" that forces the creative powers of the creator's consciousness to develop, enrich, and compete. Without a

${ }^{34}$ Ухтомский А.А. Доминанта. СПб. : Питер, 2002. 448 с. (Серия : «Психология - классика»). С. 105. 
sufficiently intense dominant, the makings of the body are simply not able to develop to a professional level. Thus, we can conclude that the presence of creative dominant is a kind of manifestation of the creative talent of the person, which, next to natural inclinations, determines the nature of the activity. The intensity of the creative dominant, which determines a person's devotion to his life's creative choice, is the most important special ability of his psychophysical apparatus.

Mental capacity, psychological endurance, "charged" with a creative dominant, help to go through all the tests of the external environment. The desire to stay at a competitive level in a professional corporation can be one of the factors that enhance creative dominant. Conversely, a decline in the desire to compete in the profession is a signal of the decay of the creative dominant.

Based on the postulates of the concept of autopoiesis of living systems, we consider the creative process as the cognitive activity of the system. And, according to the concept of autopoiesis, the cognitive area of a system's activity is determined by its biological organization: for the artist and musician, the content of a creative dominant is determined by the musical specificity of its talent, which predicts professional skills and technological algorithms.

In this context, the dominant role in the successful implementation of technological processes inherent in the work of the artist and musician is indicative: the competencies of the creative profession are a merit of consciousness, but many, even the technological moments of assimilation of musical material, are on the border of conscious and unconscious processes. The connection of consciousness and subconsciousness, intuitive insights inherent in the creative process, basically contain a creative dominant that drives the entire process of production of a creative product, playing the role of "fuel" in the process of self-organization of a professional creative person.

In the context of understanding the creative dominant as a "fuel" in the process of autopoiesis of a creative person, we turn to P. V. Simonov and P. M. Ershov, who consider the dominant as absorbing a person's determination, forming the "ultimate task of life" "35, which I. P. Pavlov called the «goal reflex» 36 .

35 Симонов П.В., Ершов П.М. Темперамент. Характер. Личность. М. : Наука, 1984. 160 с.

36 Симонов П.В., Ершов П.М. Темперамент. Характер. Личность. М. : Наука, 1984. 160 с. С. 101-102. 
An indicator of a person's presence of a powerful practical (in our case, creative) dominant, according to P. V. Simonov and P. M. Ershov, is the activity of superconsciousness (creative intuition). Scientists propose to consider the three levels of the psyche - the subconscious, conscious, superconscious - as a parameter of individuality, since the activity of these three instances is far from equally expressed in different people. Obviously, this combination determines the degree of creative giftedness of a person. A dominant need mobilizes all available human capabilities. If at the same time super-consciousness (which begins to work involuntarily) is not included in the work, then this means that the dominant is not affected. Intuition works only where the dominant personality is affected: "The search for a solution (satisfying a need) is first limited to the activity of consciousness and the sub-consciousness. But as more and more new obstacles increase in the path to dominant satisfaction, so does the effort. Reserves available to consciousness are increasingly mobilized, starting with previously proven means. Then the person moves on to the first methods used, to the search for new tools, to modeling, suggestions, conjectures: intuition begins to work. Such a gradual mobilization of efforts is a means of saving the body's strength. And if the energy impulse of need is strong, then super-consciousness is able to suggest an intuitive solution. Its productivity is determined by the degree of armament" ${ }^{, 37}$ (the presence of professional skills - O. O.-H.). Thus, we can conclude that the mechanisms of super-consciousness (in our case, creative intuition) are included in that need, which is the main one that determines the structure of motives of a given person, for the artist and musician - creative dominant.

In our opinion, creative intuition (super-consciousness) is a certain alloy of conscious efforts and reserves of the unconscious, which open up a significant part of information in the creative process. This state most accurately reflects the description of the nuclear reaction, when the energy generation itself occurs on the basis of the "accumulated temperature" of consciousness, which already lacks the "fuel" of conscious resources. "Intuition (Simonov and Ershov call it superconsciousness $-O$. O. $-H$.) is included where the motivational dominant is encountered with information deficit, with a break in the logical chain

37 Симонов П.В., Ершов П.М. Темперамент. Характер. Личность. М. : Наука, 1984. 160 с. С. 101-102. 
of thinking and action» ${ }^{38}$. In other words, if there is a lack of information resources in the sphere of consciousness, it is the creative dominant that "turns on" the reserves of the unconscious.

One of the convincing manifestations of an artist's creative dominant is «a generous expenditure of energy, since the dominant forces one to overcome the need for their savings $\gg{ }^{39}$. People in creative professions are well aware of the state of spiritual and mental stress that accompanies the birth of a stage image, musical or literary composition, and other products of creativity. This tension persists for a long time, for 24 hours a day, while the body forces are consumed with great intensity. Artists call this state "Tortures of creativity", but history does not know a single example of a voluntary rejection of these "tortures".

Based on the above-mentioned studies, we can conclude that only with the presence of creative dominant in the personality structure of the artist can his professional life be realized. The need for creative activity a creative dominant - is a motivating factor for the self-organization of the artist and musician, and the intensity and success of the process depend on the embodiment of the creative dominant in professional actions. According to I. A. Evin, «Art deals with those striving for support, for the repetition of the needs and feelings of a person, when the satisfaction of these feelings restores the need for them» ${ }^{40}$. The act of satisfying the artist's need for stage activity will result in a temporary weakening of his energetic mental stress, the so-called "release of steam", which does not mean weakening of the creative dominant, on the contrary, the act of "releasing steam" even "inflames" the creative dominant, the artist wants to experience this state over and over. The need for professional creative activity as a vital dominant "survives" both with a successful result and a failure; the positive charge of a successful action is a feeling of joy, satisfaction, the negative charge of a failed action is anger, rage, envy. Causing a different degree of excitement, with a different charge, the creative dominant ("creative itching") almost never fades and does not "release" its master into the normal, calm life of the usual man.

38 Симонов П.В., Ершов П.М. Темперамент. Характер. Личность. М. : Наука, 1984. 160 с. С. 96.

${ }^{39}$ Симонов П.В., Ершов П.М. Темперамент. Характер. Личность. М. : Наука, 1984. 160 с. С. 105.

40 Евин И.А. Искусство и синергетика. М. : Едиториал УРСС, 2004. 164 с. C. 50. 
The concept of dominant is a universal general biological principle that underlies the activity of all living things. The life of the artist and musician is based on a subconscious desire for creative activity that drives him throughout his life, from childhood onwards, determining the choice of a profession and predicting the intensity and effectiveness of implementation in it. Thus, the creative dominant is the core around which the entire personality structure of the artist and musician and his life system are built. It can be argued that for the autopoiesis system «artist and musician» the creative parameter is precisely the order parameter.

\section{CONCLUSIONS}

Analysis and systematization of modern research in the field of synergetic worldview allowed us to consider the phenomenology of the creative process of the artist and musician as autopoiesis of a living system. We study the personality of an artist and musician as an autopoiesis system; we understand the inherent creative process as an autopoiesis process.

The concept of autopoiesis can be applied to understand the creative form of consciousness that allows the system to evolve. We interpret autopoiesis of the work of the artist and musician's consciousness as a way to self-organize the system, allowing cognitive and creative functions of consciousness to manifest them. This gives the potential to achieve the most significant results in creative activity.

We consider the creative dominant to be the «energy source» for the development of a living autopoiesis system, which most accurately characterizes the formation features of reactions to environmental challenges and the direction of the processes in the system. Thus, the creative dominant confirms its characteristics of the order parameter the most informative element of the autopoiesis system, which is preserved under any circumstances and determines the direction of the system evolution.

\section{SUMMARY}

The article proposes to analyze the creative personality of an artist and musician from the standpoint of the concept of autopoiesis of living systems. This approach is justified by the fact that the autopoiesis of a living system is self-organization aimed at the evolution of a living system while maintaining its integrity and uniqueness, as well as the biological justification of the process of autopoiesis, its orientation and 
characteristic features. The autopoiesis approach in describing the creative personality and the process of creativity itself allows us to analyze the artist and musician as a living system, the biological characteristics of which determine the direction and nature of selforganization; creativity - as a process of consciously unconscious autopoiesis; creative dominant - as the order parameter of the autopoiesis system, which is the engine in the system evolution to the highest results.

\section{REFERENCES}

1. Maturana H.R., Varela F.J. Autopoiesis and Cognition. The Realization of the Living. Dordrecht : D. Reidel, 1980.

2. Varela F.J. Patterns of Life: Intertwining Identity and Cognition // Brain and Cognition. 1997. Vol. 34.

3. Аредаков А.А. Сознание в онтологиях антропного принципа // Вопросы философии. 2008. № 1. С. 45-50.

4. Бессознательное: Природа. Функции. Методы Исследования : в 4 т. Тбилиси : Мецниереба, 1978. Т. 2. 688 с.

5. Блинова М.П. Музыкальное творчество и закономерности высшей нервной деятельности / Ленингр. гос. ин-т театра, музыки и кинематографии. Л. : Музыка, Ленингр. отд-е, 1974. 142 с.

6. Варела Ф., Матурана У. Древо познания. Биологические корни человеческого познания / пер. с англ. Ю.А. Данилова. М. : Прогресс-Традиция, 2001. 224 с.

7. Васадзе А.Г. Проблема художественного чувства. Тбилиси : Мецниереба, 1978. 174 с.

8. Диагностика и развитие актерской одаренности : сб. науч. тр. / Ленинградский государственный институт театра, музыки и кинематографии им. Н.К. Черкасова. Л., 1986. 155 с.

9. Евин И.А. Искусство и синергетика. М. : Едиториал УРСС, 2004. $164 \mathrm{c}$.

10.Кассирер Э. Лекции по философии и культуре // Культурология. ХX век : антология / гл. ред. и сост. серии С.Я. Левит. М. : Юрист, 1995. 704 с. (Лики культуры).

11.Князева Е.Н. Кибернетические истоки конструктивистской эпистемологии // Когнитивный подход: монография / отв. ред. В.А. Лекторский. М. : Канон+ ; РООИ «Реабилитация», 2008. 464 с.

12.Князева Е.Н., Курдюмов С.П. Основания синергетики. Синергетическое мировидение. Изд. 3-е, доп. М. : Книжный дом «Либроком», 2010. 256 с. (Синергетика: от прошлого к будущему). 
13. Косарев А.Ф. Философия мифа : Мифология и её эвристическая значимость : учеб. пособие для вузов. М. : ПЕР СЭ ; СПб. : Университетская книга, 2000. 304 с.

14. Ласицкая Э.В. Концепция автопоэзиса: бытие, познание, деятельность // Известия Саратовского университета. Серия: Философия. Психология. Педагогика. 2011. Т. 2, вып. 4. С. 14-16.

15. Луман Н. Социальные системы / пер. с нем. И.Д. Газиева ; под ред. Н.А. Головина. СПб. : Наука, 2007. 648 с.

16. Москалев И. Е. Концепция автопоэзиса в современном научном познании [Электронный ресурс] : дис. ... канд. философ. наук: 09.00.08 . Москва, 2002. 141 c. URL : www.Synergetic.ru:

17. Рождественская Н.Ф. Психология художественного творчества: учеб. пособие. СПб. : Языковой центр филол.ун-та Санкт-Петерб.гос. ун-та, 1995. 270 с.

18. Северинова М.Ю. Архетипи в культурі у проекції на творчість сучасних українських композиторів: дис.... д-ра мистецтвозн. : 26.00.01 / НМАУ ім. П.І. Чайковського. Київ, 2013. $415 \mathrm{c}$.

19. Симонов П.В., Ершов П.М. Темперамент. Характер. Личность. М. : Наука, 1984. 160 с.

20. Ухтомский А.А. Доминанта. СПб. : Питер, 2002. 448 с. (Серия : «Психология - классика»).

21. Чехов М.А. Путь актера. М. : АСТ : Транзиткнига, 2003. 554, [6] с. (Мемуары).

Information about the author: Ohanezova-Hryhorenko O., Doctor of Arts, Professor at the Department of Solo Singing, Odessa National A. V. Nezhdanova Academy of Music 63, Novoselskogo str., Odessa, 65023, Ukraine 


\section{SEMANTIC SPACES OF INSTRUMENTAL AND ENSEMBLE PERFORMANCE: INVENTION-TENDENCY AT THE PRESENT STAGE}

\section{Povzun L. I.}

\section{INTRODUCTION}

The slogan of instrumental and ensemble art of the XXXXI centuries, like the Baroque era, is invention, but now the requirements of ingenuity have touched the sphere of instrumental intonement: the composers reject the thesis of the obligatory desire for guasi vocal singing, and the ability of the instruments to imitate the instrumental sounds, natural or non-natural phenomena, comes to the fore. Again, the principle of "playing with masks" emerges - the principle of removal, going beyond the nature of the instrumental role, which is embodied in the use of unconventional methods of sounding on the instruments and leads to unexpected timbres.

Today, the dynamics of creative manifestations mostly characterizes the phenomenon of instrumental and ensemble performing sphere, since the genetic «core» and the generalizing indicator is the personal (artistic, psychological, technological) interaction of the performers as a unique form of artistic communication and reproduction, under the conditions of which psychical and sense development of the author's text is possible.

We pay attention to the artistic and performing aspects of instrumental and ensemble art that show the ability to transform many factors, that is, become mobile, making possible the sense multiplicity of reproduction of the composition artistic idea by the performers. Well, ambiguous are the space and acoustic conditions of performance (chamber, concert, plein air), and this involves the use of adapted to the aesthetically-spatial component of artistic and instrumental expressive means (delicately-chamber, overemotionally-concert). Thanks to the mobility of articulatory and dynamic ensemble indicators, authors' compositions gain genre and aesthetic universality. Instrumental and ensemble subspecies are distinguished by their quantitative and timbral characteristic, which determines their semantic functional and mis-en-scene distinctions; an additional element of mobility is caused by 
the ad libitum author's remarks of instruments quantitative / qualitative participation in the ensemble composition.

Semantic multiplicity of ensemble combinations, a wide range of tools of instrumental and artistic expression open new possibilities for creative experimentations of composers of different stylistic directions, to search for new «timbral mixtures», which use not only components established by historical performing practice, but also non-traditional timbral combinations of instruments (introduction of instrumental components of folklore or other nationality) that reproduce an alternative view of contemporary, in particular, Ukrainian authors on the artistic trends of the era - theatricality, mimesis, role bi-functionality, performing variety.

\section{Timbral and articulatory mimesis as a tool of instrumental and ensemble expression}

Each musical instrument in the ensemble is a living part of the artistic whole, which is capable of contributing to the creation of a particular musical image with the help of its abilities. The combination of instrumental components of the ensemble (acoustic, technological, articulatory, timbral, dynamic, etc.) in different possible variants gives different artistic results. Such variability leads to analogies with painting, where the process of mixing different colors will never give twice the same shade - even a slight deviation will inevitably lead to another artistic effect.

Each instrument has its own specific instrumental articulatory basis, which is unique only to it, unlike instrumental vocality, which is a part of all instruments and differs only in the means of achieving singing on the instrument. The «bar set» on the instruments of different timbral specifics composes the multifunctional system of instrumental and performing technologies as the basis of artistic and ensemble expressiveness.

In instrumental and ensemble compositions, the use of all timbral and articulatory possibilities in quite diverse, sometimes contrasting, combinations enriches the sound with new aggregate ensemble colors, and their masterful combination leads to the deepest disclosure of the author's content (see, for example, the piano party piano part in Sonata No.1 op. 120 by J. Brahms for alternative performance with clarinet or alto, where the ability of the pianist to find the string / wind specificity of 
sound presentation depends on the result of artistic integrity and stylistic authenticity of interpretation).

Differences of musical timbre are most often determined by descriptions, analogies with certain similarities, which play a significant role in the inheritance capabilities of instruments. The expressive capabilities of the various musical timbres are due to their organological qualities and the performing and technological means of playing them: timbre is determined by the nature of the sound production, which is specific to each instrument and the instrumentalist's performing tone, which is summarized in the concept of timbre and intonation (B. Asafiev's term); the latter indicates the emotional tone of the sound, its «nerve» and «degree», the degree of psychological and semantic saturation. The synergy of ensemble timbre and intonation produces a fundamentally new sound quality, which differs from individuallyindependent instrumental timbre, creating additional timbre-component sound-imaging effects.

It can be observed on the example of instrumental and ensemble compositions of the French romantic school composers: traditional organological combinations - bowed and stringed instruments and pianos allow to find an unusual aggregate-timbral color, which becomes a semantic center of the composition (the examples are the Piano Trio by E. Chausson, the Piano Quintet by S. Frank, Cello and Piano Sonata by C. Debussy).

The timbral qualities of a certain ensemble composition sometimes appear as a direct genre feature; for example, the emotional energy, festivity, and bright volume that are important when playing plein air are provided by brass instruments, as opposed to wooden-wind ones; the chamber softness and the intimacy of expression are capable of producing stringed trios, unlike piano trios.

In a solo composition, the modulation factor of timbral color is caused by changes in the register, loud dynamics, articulatory techniques, textures that contribute to the disclosure of different sides of the image, the growth of its expression. In the ensemble composition for several instruments, the timbral change becomes a significant aspect of artistic dramaturgy related to the development of «intonational plot» by changing the organological and timbral manifestation (timbre and intonation represent the personal quality of the image), which promotes the dialogization and polylogization of the ensemble texture, filling it with new semantic layers. 
The musical instrument in the ensemble composition is the bearer of a certain image-role, the artistic properties of which are manifested with the help of timbre - a spectrum of organologically-sound qualities that distinguish and identify it in the aggregate instrumental sound. Instrumental timbre, unlike pitch, duration, dynamic performance, cannot be ordered or characterized by a certain one-dimensional magnitude. The instrumental timbre-image cannot be ethically identified as a positive hero or an antihero (unlike a theater or opera character); specific characteristics of various musical timbre are most often determined by descriptions, analogies, which allow to give a musical and instrumental image to specific personality traits and to distinguish it due to characteristic features and associations (sensory, visual, audio).

Timbral and instrumental mimesis, as an organological ability to imitate, involves the reproduction of specific articulatory means of specific artistic and sound images, embodied in the author's idea of the composition:

- sound imitation of natural phenomena such as echo, wind noise, thunder, water play, waterfall;

- timbral imitation of the sound of other instruments, which presupposes the principle of expanding the articulatory-instrumental «vocabulary» by the involvement of other instrumental tools;

- intonational inheritance of certain national cultures, in particular, attraction of national articulatory and intonational indicators to create exotic sound color;

- style imitation - the artistic stylization of music by a certain author, using characteristic features of his style or musical «monograms».

The instrumental ability to mimesis does not imply the possibility of complete replacement of a specific instrument, but determines the quality-similarity to the conditional timbral meaning - a symbolic closeness to the sound associations with a particular instrument-image.

The study of the sound-inheriting potential of various instrumental groups gives the hypothesis that the volume of timbral mimetic possibilities determines the relevance and demand of a group of stringed and bowed and wooden wind instruments in the chamber and ensemble art sphere, and copper brass instruments are less able to "masking" their own organological qualities, so their use is limited to a specific sound role.

The organological paradigm of ensemble performance was formed over a long historical period, gradually collecting and refining instrumental examples that met the artistic and aesthetic demands of 
society and the spatial conditions of performance (chamber hall / concert hall / plein air). The decisive factor in the processes of selection and crystallization of the organological «core» of the instrumental and ensemble sphere were the artistic (articulatory, dynamic, timbral) properties of the instruments.

The value of the instrumental factor in the artistic and semantic concept of ensemble composition has increased significantly during the XX century: creative experiments of contemporary artists in search of new sounds have completely changed the traditional ideas about the soundness of instrumental compositions and the natural properties of instruments. Operation of sound, timbre, intonation as such, the composition with the "primary features» of the music material determines the creative search of contemporary authors, since music creativity and material are inevitably linked, musical creativity implies updating of resources that are not yet exhausted ${ }^{1}$.

The search for new multicolored sounds leads to the use of not only the natural artistic and technological qualities of instruments (with all the variety of ensemble assimilation of traditional methods of sound production), but also to the combination of musical and extra-musical sound effects: the latter go beyond the concept of instrumental sound production and become tools of the background layers - noise, phonism, tone (in particular, playing with the reel for timpani on the open strings of the piano in the piano quintet «Deo Volentum» by A. Tomlyonova), reveal a tendency to imitate the sound of not only certain instrumental timbres and natural phenomena, but also artificial phenomena (in the compositions of Tsepkolenko the combination of acoustic instruments and electronics experiments with analogical digital sound).

Due to fundamental changes in the general image of the modern world, the musical and aesthetic criteria have undergone significant changes, causing a rethinking of ideas about musical sound (sonority as a relevant type of modern composition technique), which opens a wide artistic space for the search of new soundings due to the immense scale of organological and articulatory, dynamically-agogic indicators. Experiments with any techniques of sound production, which is one of the characteristic features of sonoristics, are constantly updated with new

1 Булез П. Творчество, техника, язык // Homo musicus'99 : альманах музыкальной психологии. М. : МГК им. П. И. Чайковского, 1999. Сборник 25. C. 19-25. 
technological findings and greatly expand the possibilities of artistic, figurative and sound-imaging spheres of ensemble expression.

As E. Nazaykinsky points out, in the process of sound motion, noise and background elements are clearly distinguished, as well as the timbre of sound (somewhat perceived at the moment) and the timbre of the instrument (somewhat imaginary) in the aggregate. That means, the timbre manifests itself outside the category of formed pitch (height), volume, duration and spatial localization - it absorbs the effects of all other properties and acts as a characteristic of sound as a whole. "There is something interesting, useful and justifiable that the hearing takes from of the newest. The separation of sounds from their real sources is ensured by the multiplicity of instruments, voices, sound-producing objects and the fundamental diversification of their use. Here we are dealing with total timbre, similar to the noise of leaves, rain, waves, when many small vibrators, pathogens, resonators are mixed together. Therefore, unlike timbre and phonism, for which the spectral characteristics of the resonant body of the instrument and the vibrating body itself are important, with sonority, the noise activity of pathogens - bows, and with it the articulatory component of musical phonetics becomes more important"2.

Artistic tools of expression are associated with the distribution of sounds over time and with timbral color of sound presentation, which is formed by the combination of musical and non-musical means of expression (timbre, as the aggregate quality of sound, depends on many components: harmonic and non-harmonic partial tones, sound attack, vibration etc.). In the aggregate of sound components that are under the influence of the laws of the musical organization, the timbre, equally with other sound components, is «a source of structural radiation that permeates the musical texture and determines its specific character and shape» ${ }^{3}$.Investigating the spectral properties of the timbre, M. Garbuzov distinguishes the «objective» component of the timbre recorded by the spectrometer, and the «subjective» that occurs in our hearing aid as a result of the interaction of objectively existing audio overtones and all other partial tones. However, it is precisely from the partial tone ratio of

${ }^{2}$ Назайкинский Е. Музыка - звуковой мир: Тембр - фонизм - сонорность // Советская музыка. 1986. № 12. С. 80.

3 Бобровский В. Тематизм как фактор музыкального мышления. М. : Музыка, 1989. С. 22. 
the «objective» and «subjective» component that determines the timbre of the partial tone, and accordingly the timbre of the sound ${ }^{4}$.

According to Ukrainian researchers, the current era is an era of comprehensive detailing of the use of musical parameters and a radical modification of the musical language. Differentiation of means of musical expressiveness, achieving the functional independence of elements (parameters) due to their detailing leads to the formation of new principles of relations between them: if the classical phonematics of «European» musical language fit within the limits of the threedimensional coordinate system «height (pitch) - duration - dynamics» ${ }^{5}$, then a new intonational and sonoristic paradigm of contemporary music is represented as four-dimensional, with the addition of timbral and articulatory sound characteristics as an equal coordinate that becomes an independent paramount differential sign. Based on the above, V. Larchikov concludes that height (pitch), dynamics and duration are linear characteristics, while the new - fourth - differential feature has the properties not of coordinate as such, but of its own integral coordinate system. It appears as internal multidimensionality, the one that has a lot of parameters. It was the emancipation of the timbral and articulatory complex of parameters that led to the possibility of the infinite expansion of the "sound universe», which was observed in the second half of the $\mathrm{XX}$ century. The aesthetic sphere includes sounds and acoustic phenomena that were not previously related to music - a wide range of phenomena of noise genesis, sounds of nature and various manifestations of human activity («specific music»), etc. Humanity comes to the concept of infinity of timbral resources and sound capabilities of musical language ${ }^{6}$.

At the present stage, the discoveries of previous generations of artists in the field of instrumental expressive and aggregate timbral means are prolonged by identifying new articulatory possibilities in the intonation sphere, which, respectively, leads to the expansion of «articulatory performing vocabulary of the era» and to awareness of the infinite

\footnotetext{
${ }^{4}$ Гарбузов Н. А. Зонная природа тембрового слуха. М. : Государственное музыкальное издательство, 1956. С. 38

5 Шип С. Музыкальная речь и язык музыки. Одесса: ОГК им. А. В. Неждановой, 2001. С. 168.

6Ларчіков В. Музично-виконавський арсенал сучасного віолончеліста // Виконавське музикознавство : науковий вісник НМАУ імені П. І. Чайковського : збірка наукових праць. Київ, 2009. Вип. 82. С. 43.
} 
timbral potential in instrumental and ensemble combinations. And if in the previous historical stages the leading role in the creation of a certain «color» of the aggregate sound was played by the composition and the author's conception, today the leading role in the creation of the whole artistic composition belongs to the performers.

E. Nazaykinsky confirms our opinion: the emancipation of color is the result of isolation from the instruments of the vibrator with its independent «intonational behavior», the focus of attention towards illusory sources of sound. Here on a leading place there are «bows», subject of the musician's will - their articulatory drawing, whistling, whispering, muttering and other musical and phonetic effects. The concept of phonism is especially close to pianists, because the multiplicity of vibrators (strings and string choirs, rigidly fixed on the common resonator base of the piano and clearly separated from it) allows to achieve a tonal high-pitch uniqueness of sound against the background of timbral unity. Even more important is that with indirect timbral control using keyboard mechanics, the pianist can directly adjust the background effects of common polyphonic sound, using pedals and a thoughtful distribution of volume between individual components of the texture ${ }^{7}$.

The tendency for timbral inheritance mostly touched the piano, since the keyboard instrument - as an «orchestra substitute» - is genetically capable of timbral color. This ability in the newest stage of development of instrumental and ensemble creativity is used in its traditional «inclination» (imitation of the timbre of orchestral instruments), as well as in reproduction of the organological clavier row with all its predecessors and descendants. It is necessary to recall that the search for new sounds within the fixed piano timbre occurred in the compositions of composers of different instrumental schools - C. Debussy, M. Ravel, S. Frank, R. Strauss, E. Grieg, O. Skryabin, O. Messian, marked by a tendency to compare the clavier timbre of pedal sounds with the sounds of guasi organ, guasi cembalo, guasi harpsichord, guasi electro-piano, guasi electro-organ, which opposes the orchestral and clavier specificity of the embodiment. The characteristic integrity of multi-sounding, which has always determined the essence of the clavier, in the specifics of ensemble embodiment breaks down into the multiplicity of historically

${ }^{7}$ Назайкинский Е. Музыка - звуковой мир: Тембр - фонизм - сонорность // Советская музыка. 1986. № 12. С. 83. 
tested timbral techniques and carries out timbral «transformation» within the framework of fixed mechanics. To this there can be added an indication of the new timbral colors actively used by composers in ensemble music at the present stage: guasi harp, guasi electric guitar, guasi contrabass, guasi bandura, guasi percussion instruments.

The list of "timbral resources" of the keyboard does not exclude attention to basic classical and romantic settings: the cantilena and the desire to bring the instrumental sound closer to the vocal cantabile certainly remains the standard of sound not only for the piano, but also for all instruments and as a sound culture determines the level of professional skill of the performers.

In the modern culture of piano sound traditional articulatory techniques have undergone a significant transformation - the use of the instrument's percussion capabilities, playing the open strings of the piano, percussion on the instrument cover (sometimes with the open right pedal), «prepared» piano (with the use of auxiliary objects), emphasized piano resonance, a special commitment to imitation of percussion, stringed and plucked (folk and ancient) instruments, widespread use of clusters, curl effects, etc.

The processes of expansion and diversification of the timbral and instrumental potential of the aggregate ensemble sound field confirm the general historical tendency of constant updating of technological and artistic expressive sphere of ensemble performance.

\section{Instrumental theatre in the modern Ukrainian dimension}

The semantic multi-vector of instrumental and ensemble genres, the wide range of articulatory and timbral, dynamically-agogic means of joint expression make this sphere especially attractive for the creative search of composers of almost every artistic direction. The increased attention to instrumental and ensemble performance is confirmed by the considerable number of works of contemporary Ukrainian composers, for whom instrumental and ensemble genres have become a priority area of artistic creativity, since they have been able to actualize a number of the major international trends in world music culture.

According to L. Kyyanovska, intensive search for innovative means of expression allow the chamber and instrumental music to remain invariably a sphere of intense intellectual work in mastering the musical 
and dialogical form of «higher psychological complexity» ${ }^{8}$. According to Pavlyshyn, in the second half of the XX century the concept of «chamber ensemble» disappears, and instead the program concept of «instrumental theater» emerges, which, in addition to the music itself and a certain plot generalization, includes the actor's actions of performers. Instrumental theater has many individual variants"9.

The tendency for theatricalization of instrumental and performing arts has become a reproduction of the contemporary artistic integrative approach, characterized by the vision of intertextual identities in the diversity of genres and style traditions. Musical and instrumental theater on the verge of the XX and XXI centuries is a striking example of such tendencies, and at the same time it is an appeal to the primary models of musical, in particular, instrumental and ensemble creativity, which was a part of syncretic action (combination of music, words, dance, and theatrical action). However, speaking of a certain synthesis of the arts, we are aware of a new level of artistic phenomena fusion, resulting in not just mutual genre assimilation, but the emergence of a new expressive form of performance. And, as E. Bondar points out, an art work must be a «revelation», it must surprise, give the listener, the viewer a new image, powerful, intense by the force of emotion. Artistic means of contemporary performance (intonational and artistic, motor, visual, etc.) have their own volume of semantic and expressive possibilities, «conditioned both by the objective properties and vital connections of this means, as well as by the ability of this means, developed in the course of the musical historical process, to cause certain ideas and associations" $"$.

8 Кияновська Л. Специфіка камерно-інструментального мислення Мирослава Скорика (на прикладі творчості останнього двадцятиріччя) // Камерно-інструментальний ансамбль: Історія, теорія, практика: Виконавське мистецтво: наукові збірки ЛНМА імені М. В. Лисенка. Львів : Сполом, 2011. Вип. 25. С. $7 .$.

${ }^{9}$ Павлишин С. Еволюція камерного ансамблю // Камерно-інструментальний ансамбль: Історія, теорія, практика: Виконавське мистецтво: наукові збірки ЛНМА імені М. В. Лисенка. Львів : Сполом, 2015. Випуск 34. С. 17.

${ }^{10}$ Бондарь Е. Современное хоровое исполнительство : новый синкретизм или синтез искусств // Музичне мистецтво і культура : науковий вісник : збірка наукових праць ОНМА ім. А. В. Нежданової.. Одеса : Астропринт, 2012. Вип. 15. С. 341. 
The use of the term «theatricalization» implies a set of specific means and techniques inherent in theatrical art. We consider theatricals in the instrumentalists' creative work as:

- performance and play of a certain role in a musical composition;

- performance and play in a certain «instrumental mask» (a play in a play);

- a certain manner (method, reception) of artistic and instrumental embodiment;

- active use of additional theatrical means (facial expressions, gestures, stage action);

- conscious underlining of the means of stage expression (overemotionality, over-dynamics of instrumental expression);

- reinforcement of the program-plot aspect of the composer's plan, which implies a certain model of musical and dramatic «action".

According to A. Samoilenko, theatricality is an important aspect of the instrumental and performing play, which the author defines as a multifunctional epiphenomenon of musical semantics, which simultaneously addresses the cultural, artistic and compositional, textual, stylistic and psychological conditions of musical creativity ${ }^{11}$.

Of course, mostly thearicalization in the presentation of musical material is used by performers in the concert and stage genres, but chamber and ensemble work has historically found its place on the concert stage. And at the present stage in the instrumental and ensemble performance through the interaction of several genres (instrumental, music and word, dance, video, stage), a number of theatrical features are reproduced: special organization and sense of artistic space and time, increased share of the play and gesturing, the presence of conductor and actor's actions from the side of musicians-instrumentalists.

Different aspects of the embodiment of theatricality in instrumental music are manifested in the specifics of the choice of imagery, dramaturgy, and composition, directing and performing factors, since in the performance action there is a combination of two worlds conditionally compositional and realistically performing. Formation of a complete composition of the ensemble work involves simultanic instrumental dramaturgy, which, according to A. Nivelt, is a type of

11 Самойленко А. Музыкознание как «живая история» культуры: К проблеме диалогичности гуманитарного знания // Трансформація музичної освіти: культура та сучасність: матеріали музикологічного семінару. Одеса : Астропринт, 1998. Ч. 1. С. 91-102. 
dramaturgy of the highest order and is based on the interaction of two or more dramatic development lines, including multifaceted genre base, temporal and spatial indicators of musical and stage composition ${ }^{12}$.

The opera director O. Shchoholiv, studying the origins of performance and theatrical action, came to the conclusion that actorsmusicians are able to make music by acting, because they not only hear music, but also «see» it ${ }^{13}$. Y. Vysotsky has a similar opinion, arguing that the perception of music is not only a matter of hearing but also of sight, so it requires an organic combination of the performing arts with theatrical $^{14}$.

Theatricalization of the instrumental and ensemble performing space implies a certain spatial transformation, as the listener becomes a listenerspectator. And this requires the extension of the boundaries of the established listening space. However, it should be noted that auditory and visual connections in music have a long tradition: seven musical sounds of the Middle Ages indicated seven main colors - red, orange, yellow, green, blue, indigo and purple. In the XVII century, voices in scores were designated with certain colors: soprano - red, alto - yellow, tenor - green, bass - blue. Color associations also relate to tonal perception, in particular, known, but not well-researched, facts of color hearing (synopsis), which was characteristic of M. Rimsky-Korsakov, O. Skryabin, B. Asafiev, O. Messian. S. Lyudkevich, who had his own mind on the beauty of individual sounds and the laws of their combinations («musical art operates with tones and their combinations»), called the phenomenon of the interaction of music and colors «a sense of tonation» ${ }^{15}$.

Characteristic of contemporary composers, the sensitivity to the musical space is manifested in particular attention to the acoustic environment in which the performance takes place; sometimes it is the

12 Нивельт О. Симультанный тип оперной драматургии // Музичне мистецтво i культура: науковий вісник ОДМА імені А. В. Неждановой . Одеса : Друкарський дім, 2006. Кн. 1, вип. 7. С. 16.

13 Щоголів В. Музичний театр «Зона мовчання»- дослідження джерела // Виконавське музикознавство : науковий вісник НМАУ імені П. І. Чайковського.. Київ, 2009. Випуск 82. С. 268.

14 Высоцкий Ю. Мистерии театра скрипки // Зеркало недели. 2000. № 16 (289). С. 20.

15 Людкевич С. Про красу звуку : Дослідження, статті, рецензії, виступи // Історія української музики / [упор., ред., перекл., вст. ст. З. Штундера] ; Інститут українознавства ім. I. Крип'якевича. Львів : Видавництво М. Коць, 1999. Т. 1. Вип. 5. С. 205. 
use of room acoustics to create a multidimensional sound associated with a particular location of the performers (on and off the stage, at different corners of the hall, the movement of musicians around the listeners, the combination of real sound with electronic recording).

Substantial changes are taking place in the sphere of the musical performing and listening space, presented in the works of contemporary authors in quite a diverse way:

- changing the «listening position» with the transition from close-up to general (and vice versa) is perceived as a rapid jump in sound quality (for example, from tutti ffff to ppp of flutes and violins); wide air space of multi-octal duplication with gradual filling with various rhythmic variants; during a gradual change in dynamics the effect of zooming in or out is created;

- one of the characteristic features of contemporary music sound is the multiplicity and sophistication of «long-range plans»: the comparison of background and relief, close and distant plans (the latter are often quiet in sound and slow in motion or very still), contrasting use of «close-up» (maximum loud with characteristic instructions «marcatissimo», «furioso»);

- typical is the relationship aggravation of «dense» and «transparent» texture, hence the violation of the continuity of sound volume, «torn» texture (super-dense texture is formed with the help of saturated chords, sometimes with melodic «germination» of individual voices, clusters);

- one of the means of reproducing dramatic tension is filling the entire space with contrasting thematic layers that unfold independently, forming a multidimensional space - as a «space of action».

According to N. Gerasimova-Persidskaya, in complex-organized spaces there appears an opportunity for not one musical phenomenon to acquire a volume, but for many phenomena to interact in different ways, forming a complex system of sound volumes correlation ${ }^{16}$.

An example of the artistic interaction of volumetric and dimensional, sonorously-dynamic and spatial contrasts in the ensemble texture is A. Tomlyonova's composition «Whispers and Cries», which reproduces the expression of human being and the polar points of its sound

${ }^{16}$ Герасимова-Персидская Н. Выход к новым принципам пространственновременной организации музыки в переломные эпохи // Музыкальное мышление: сущность, категории, аспекты исследования : сборник статей. Київ : Музична Україна, 1989. С. 61, 62. 
manifestation (a composition written on the basis of the Swedish film directed by Bergman).

Using the chronotopic interaction of historical and temporal, dynamical and timbral indices, Y. Gomelskaya in the composition "The Wings of the Eastern Wind" (for flute, clarinet, violin, cello and piano) unveils her own vision of Eastern culture, without resorting to a specific national and intonational color, unlike the duet «Rising. East - West» for piano and percussion, in which the ensemble combination shows intonational and sound juxtaposition of cultures. The author achieves stylization, not through quotations, but through the use of unconventional techniques or the use of auxiliaries (similar to the piano improvisation and percussion on the open strings of the piano imitate the sound of a multi-stringed Indian instrument).

According to G. Zavgorodnya, the bright personality of Y. Gomelskaya's is directly connected with the extreme authorization of musical style and genre searches, which leads to the personalization (separation) and special independence of the leading regularities of the structure of such a phenomenon as musical language. The fundamental principle of organizing sound material is the composer's installation of various combinatorics associated with the primary elements of the musical language as a structural unit that «encodes» in itself both the content and the overall compositional potential ${ }^{17}$.

Turning back to instrumental and ensemble creativity, first of all, Y. Gomelskaya develops a scenario of instrumental relationships, as the titles of the compositions eloquently attest: «Trap for Two» for soprano saxophone and alto saxophone; «... Herbarium... music of memories...» for violin, alto and cello; "Carl and Clara" for clarinet and piano, "Synopsis of Symmetries" for flute, alto and cello; «From the bottom of the soul» for string quartet; «Forgotten Ritual» for flute, alto saxophone, piano and percussion; «Through the Gothic Mosaic Crystals» for flute / alto flute, cello and piano, etc.

The storyline unfolds in rather unexpected dialogues of instrumental timbres, and the author pays special attention to the spatial properties of the ensemble texture, forming a specific timbral density of sound space, while separating each timbre personality of the musical action. For

17 Завгородняя Г. Полифонические аспекты организации музыкального пространства в творчестве Ю. Гомельской // Музичне мистецтво і культура. Науковий вісник ОДМА імені А. В. Нежданової: збірка наукових праць. Одеса : Друкарський дім, 2010. Вип. 11. С. 312. 
example, in the duet «Dia Dem» violin and cello monologues exhibit boundary poles - the contrast of two principles in nature, in which, according to G. Zavgorodnya, the opposite of divine and devilish, male and female, incompatible bases of thinking of different types of personality is determined ${ }^{18}$.

Interesting is the instrumental and timbral view of Y. Gomelskaya on the archaic layers of pagan Slavic rites in the composition «To the sun. Spring Ritual»: the author created two versions of the composition, the first of which was a two-piano, the second - a piano quintet for the traditional composition (reminiscent of the history of the organological transformation of J. Brahms Piano Quintet, op. 34).

Manifestations of role bi-functionality are observed in the use of the verbal series (singing, declamation of the text) in the ensemble texture of the instrumental composition, when the performing musical instrument is overlaid with the spoken instrumental replicas. This allows to achieve not only the necessary emotional but also plot development: for example, in the Gomelskaya's "Fonium-Folk" Quartet, the voices of instrumentalists forming a kind of verbal polyphony are gradually added for dynamic growth and textural compaction.

A similar enrichment and «additional» timbral saturation of the ensemble texture, without increasing the number of instrumental participants, is reached by A. Tomlyonova in Sonata for alto and piano, which provides simultaneous or alternate holding of several instrumental parts by one performer (in particular, in the finale, the piano party switches to bell sounds); in the Piano Trio by K. Tsepkolenko «Doors wide open» the pianist plays percussion instruments. Such «universal instrumentalism» is a historical dialogue with the Baroque era, when the standard of the perfect ensemble was the ability to master all the instruments of composition (J. Matheson's tractate «The Perfect Kapellmeister»).

All of the above-mentioned confirms the importance of the performing factor in the process of embodiment of the author's idea and allows us to consider the leading aspect of the instrumental and ensemble creativity of the modern period, since it is the conceptual-emotional

18 Завгородняя Г. Полифонические аспекты организации музыкального пространства в творчестве Ю. Гомельской // Музичне мистецтво і культура. Науковий вісник ОДМА імені А. В. Нежданової : збірка наукових праць. Одеса : Друкарський дім, 2010. Вип. 11. С. 319. 
integrity of the artistic realization and the musical integrity of the instrumentality that depends largely on the artistry and mastering.

Thus, instrumental theatricalization is an important aspect of ensemble performance, which simultaneously addresses the cultural, artistic, compositional, textual, stylistic, and psychological conditions of musical creativity.

\section{CONCLUSIONS}

The processes of expansion of the ensemble «artistic and sound field», which at the present stage happen through the introduction of non-academic instruments, new techniques and means of sound production on the instruments of the classical sample, attracting «noise» objects to diversify the aggregate sound, at the beginning of XXI century, confirm the historical tendency of constant updating of technological and artistic expressive sphere of ensemble performance.

The transformation of ideas that occur in the interpretation of traditional musical instruments, active experimentation with them causes a significant expansion of the palette of their expressive means, the introduction of unknown before and often significantly different from the «classical» performing techniques, means of sound production, articulation. And this requires the systematization of their application and the creation of a special reference and theoretical base with generalization of new information on the means of sound production.

All modern inventions in the instrumental and articulatory sphere are aimed at reproduction of certain timbral and sound qualities that can cause symbolic figurative and semantic associations. And therefore, the volume of timbral mimetic abilities determines the relevance of certain instruments participation in the musical-plot action.

An analysis of the mimetic ability of instruments with different peculiarities of musical «breathing» to imitate sound complexes (natural, other instrumental, extra-natural) revealed the advantage of stringed bowed instruments over stringed plucked and wind instruments in the number of «sound roles», which is largely due to the organological paradigm of ensemble performance.

The modern instrumental timbral mimetic trend has greatly expanded the traditional «imitation zone» of the piano, which is used both in its traditional «inclination» - guasi orchestral instruments, and for playing the clavier in a variety of predecessors and descendants (guasi organ, guasi cembalo, guasi harpsichord, guasi electro-piano, etc.) to which new timbral colors of other instrumental sphere (guasi harp, guasi electric 
guitar, guasi contrabass / bass, guasi bandura, guasi percussion instruments) are added.

On the verge of the XX-XXI centuries the concept of chamber ensemble begins to include the concept of instrumental theater in its subject content; the latter receives a plurality of individual-author manifestations, the purely sound realization of the author's composition is complemented with the plot-acting and bi-instrumental actions of the performers, which increases the importance of the performing factor in the process of embodying the artistic concept, and extends genre communication to the concept "performer - listener/spectator".

\section{SUMMARY}

Instrumental and ensemble performing sphere becomes an area of creative experimentations of contemporary authors, a sphere of search for new timbral and ensemble combinations, which use not only components established by historical performing practice, but also nontraditional timbral combinations of instruments that reproduce the alternative view of Ukrainian artists on artistic aspects.

At the present stage, the discoveries of previous generations of artists in the field of instrumental expressive and aggregate timbral means are getting their prolongation by identifying new articulatory possibilities in the intonational sphere, which leads to the expansion of «articulatoryperforming vocabulary of the era» and to the conscious awareness of instrumental and ensemble connections.

Timbral mimetic inventions in the instrumental and articulatory sphere are aimed at reproduction of certain sound qualities that cause symbolic figurative and semantic associations (sensory, visual, audio). The mimetic ability of the instrumental series significantly expands the artistic spectrum of the sound capabilities of ensemble performance. If in the previous historical stages the leading role in the creation of a certain «color» of the aggregate sound was played by the composition and the author's conception, at the present stage the leading role in the creation of the artistic whole composition belongs to the performers.

Introducing the techniques of theatricalization into the ensemble compositions of contemporary authors brings to the subject circle the concept of instrumental theater - musical and instrumental program plots-performances with a planned script action. This increases the importance of the performing factor in the process of artistic conception embodiment and makes possible the musical and video integrity. 


\section{REFERENCES}

1. Бобровский В. Тематизм как фактор музыкального мышления. М. : Музыка, 1989. С. 22.

2. Бондарь Е. Современное хоровое исполнительство : новый синкретизм или синтез искусств // Музичне мистецтво і культура : науковий вісник: збірка наукових праць ОНМА ім. А. В. Нежданової . Одеса : Астропринт, 2012. Вип. 15. С. 339-349.

3. Булез П. Творчество, техника, язык // Homo musicus'99 : альманах музыкальной психологии. М. : МГК им. П. И. Чайковского, 1999. Сборник 25. С. 19-25.

4. Высоцкий Ю. Мистерии театра скрипки // Зеркало недели. 2000. № 16 (289). С. 19-21.

5. Гарбузов Н. А. Зонная природа тембрового слуха. М. : Государственное музыкальное издательство, 1956. С. 38.

6. Герасимова-Персидская Н. Выход к новым принципам пространственно-временной организации музыки в переломные эпохи //Музыкальное мышление: сущность, категории, аспекты исследования : сборник статей. Київ : Музична Україна, 1989. С. 54-64.

7. Завгородняя Г. Полифонические аспекты организации музыкального пространства в творчестве Ю. Гомельской // Музичне мистецтво i культура. Науковий вісник ОДМА імені А. В. Нежданової : збірка наукових праць. Одеса : Друкарський дім, 2010. Вип. 11. С. 312-321.

8. Кияновська Л. Специфіка камерно-інструментального мислення Мирослава Скорика (на прикладі творчості останнього двадцятиріччя) // Камерно-інструментальний ансамбль: Історія, теорія, практика: Виконавське мистецтво: наукові збірки ЛНМА імені М. В. Лисенка. Львів : Сполом, 2011. Вип. 25. С. 7-16.

9. Ларчіков В. Музично-виконавський арсенал сучасного віолончеліста // Виконавське музикознавство: науковий вісник НМАУ імені П. І. Чайковського : збірка наукових праць. Київ, 2009. Вип. 82. С. 43-61.

10. Людкевич С. Про красу звуку : Дослідження, статті, рецензії, виступи // Історія української музики; Інститут українознавства ім. І. Крип’якевича. Львів : Видавництво М. Коць, 1999. Т. 1. Вип. 5. $495 \mathrm{c}$.

11.Назайкинский Е. Музыка - звуковой мир: Тембр - фонизм сонорность // Советская музыка. 1986. № 12. С. 75-82. 
12.Нивельт О. Симультанный тип оперной драматургии // Музичне мистецтво і культура: науковий вісник ОДМА імені А. В. Неждановой. Одеса : Друкарський дім, 2006. Кн. 1, вип. 7. C. $16-25$.

13.Павлишин С. Еволюція камерного ансамблю // // Камерноінструментальний ансамбль: Історія, теорія, практика: Виконавське мистецтво: наукові збірки ЛНМА імені М. В. Лисенка. Львів : Сполом, 2015. Випуск 34. С. 16-21.

14.Самойленко А. Музыкознание как «живая история» культуры: К проблеме диалогичности гуманитарного знания // Трансформація музичної освіти: культура та сучасність: матеріали музикологічного семінару. Одеса : Астропринт, 1998. Ч. 1. C. 91-102.

15.Шип С. Музыкальная речь и язык музыки. Одесса: ОГК им. А. В. Неждановой, 2001. 296 с.

16. Щоголів В. Музичний театр «Зона мовчання» - дослідження джерела // Виконавське музикознавство : науковий вісник НМАУ імені П. І. Чайковського. Київ, 2009. Випуск 82. С. 263-275.

\section{Information about the author:}

Povzun L. I.,

Doctor of Art Studies, Professor of the Department of Chamber Ensemble, Head of the Department of Chamber Ensemble, Odessa National A. V. Nezhdanova Academy of Music 63, Novoselskogo str., Odessa, 65023, Ukraine 


\section{HISTORICAL AND PHILOSOPHICAL DISCOURSE OF MUSIC ORATORY IN THE PROJECTION OF DOMRA PERFORMANCE}

\section{Oliinyk O. L.}

\section{INTRODUCTION}

Science and at the same time the art of oratory, which originated in the «cradle of European civilization» - antiquity, was re-interpreted in the septem artes liberalis, the heart of the Christian wisdom in the Middle Ages, subsequently lost its leading position, giving way to other philosophical studies. Its intense revival happened unexpectedly in the last century, when oratory was again widespread in the sociocultural environment and revealed its practical essence in the processes of modern communication. The researchers also point out the natural need of technocratic age people to find the best forms of communication and note several major causes of the rapidly growing popularity of oratory. It is noteworthy that these causes are found in different ways of spiritual and social life and have both intellectually communicative and purely pragmatic characteristics.

Going back to the historical origins, we find that in the Ancient times two basic traditions of oratory were formed. The first tradition is most vividly represented in the works of the Ancient Greek philosopher Aristotle (IV century BC). Within it, oratory is defined as «the art of persuasion.» According to this tradition, the main task of the speaker is to convince the audience.

The second tradition is most vividly represented in the works of the Ancient Roman orator Quintilian (I century AD). Within it, oratory is defined as «the art of speaking gracefully.» According to this tradition, the speaker's job is beauty, sophistication, and elegance of expression. Persuasion appears to be possible, but not by far the main purpose of the speaker ${ }^{1}$.

1 Колотілова Н. Риторика: навч. посібник. К.: Центр учбової літератури, 2007. C. 11. 
The Christian tradition of oratory is manifested through the central position of science and art at the same time in the system of the trivium (grammar, oratory, dialectic), where the metaphysical normativity of grammar is revealed as the starting point, and the philosophy of development, i.e. dialectics, is the final summation.

\section{Principles of speech and its impact on musical performance}

«XX century is the century of personification of personality, that is, the individual identity of the individual, growing dissimilarity of each individual from the others. This dissimilarity increase leads to complications in communication between people and thus causes the need for a society in a science called oratory which aims to teach people to communicate",

The second reason for the current actualization of oratory as a science is the expansion of public spheres of oral communication, the increase of channels of transmission of oral information (radio, television, in recent years - public networks):

«The purely communicative reasons for the revival and development of the language influence science of the twentieth century can be attributed to the development of communication itself. Our time is characterized by a dramatic expansion of the sphere of communication of people, an increase in the number of situations in which we must engage in communication and convince each other. The meaning of oral language has expanded significantly, it is beginning to perform more and more diverse functions, and is playing an increasingly important role in society, which in turn leads to the need to find new ways of communication, to pay more attention to different styles of communication", 3 .

Finally, the third reason for the need to master the art of oratory is called the economic realities.

The structure of oratory perfectly takes into account the psychological nature of human perception, the ability of thinking to build a logical chain in the grasp of every communicative object that is the focus of attention of both the author and the recipient.

\footnotetext{
${ }^{2}$ Бондаренко В. Риторика. Харків: Вид-во ХНАДУ, 2008. С. 8.

${ }^{3}$ Бондаренко В. Риторика. Харків: Вид-во ХНАДУ, 2008. С. 9.
} 
The traditional five parts of oratory (Inventio, Dispositio, Elocutio, Memoria, Pronuntatio) ${ }^{4}$ are opened by a stage of primary design, concentrated in the knowledge and skills of Inventio - invention. They determine the qualities of the four further components of the oratory whole: the art of «continuation» once given as an oratory theme at the level of high abstraction. Speech orientation of the oratory leads to «ubiquity of legato» ${ }^{5}$ in the interaction of ethos and the affect of oratory expression, which is the special content of the fourth part of oratory Memoria.

The verbal nature of oratory after defining the main tasks in Inventio is based on the doctrine of Dispositio (teaching) and Pronuntatio (action); in the first of them the logical differentiation of the oratory speech is followed to the greatest extent, while in the latter the physical features of verbal presentation (facial expressions, diction, declamatory principle, gesture, etc.) are working.

The application of compositional principles of the oratory in various fields of human activity, including fine arts or music involves a careful preparation and process professionalization of the chosen kind of activity, one way or another related to communication and broadcasting, and more broadly to the correct presentation of the related text. This constitutive property of the oratory principles is clearly outlined in the first stage: the invention, since it requires such an arrangement and structuring of the original idea in a verbal (or non-verbal) form, which will be convincing and clear in the subsequent process of presentation and argumentation.

For the evolution of a tool that integrates from the folk to the academic sphere, it is very important to learn the type of composition that operates the techniques of logical construction of artistic integrity and unlike the spontaneous improvisational mode of folk music it applies the detailed and proven principles of development.

The purpose: «to propose a whole set of provisions and in such a sequence that they do not contradict each other, but specifically move from one part to another until a legitimate conclusion» ${ }^{6}$ first of all sets

4 Захарова О. Риторика и западноевропейская музыка XVII - первой половины XVIII века. М., 1983. С. 34-40.

5 Захарова О. Риторика и западноевропейская музыка XVII - первой половины XVIII века. М., 1983. С. 37.

${ }^{6}$ Мацько Л. Риторика: навч. посіб. 2-ге вид., стер. К.: Вища школа, 2006. C. 45 . 
itself the second section of oratory, disposition, beginning the stages of development and demonstration of the main ideas formulated and outlined in Inventio.

Despite the clarity and transparency of the logical and structural rules of oratory, they are by no means schematized in scholastic unambiguous terms, but have a proper sense of semantic entropy, which focuses primarily on the Elocutio stage.

«Elocution (Latin eloguor - I say, teach) is the third section of classical oratory, which reveals the laws of linguistic expression of the subject of communication. The main sense of elocution from classical rhetoric has gone into modern stylistics (the doctrine of styles and the doctrine of tropes and figures). The first and the second stage development, the inventions and dispositions, has become a linguistic figurative expression and, as a result, an additional substantive, evaluative, emotional, volitional effects.

To conclude our review of the oratory stages, let us focus specifically on the last, fifth level, Pronuntatio. It is also extremely important for the rhetorical foundations of music art because, being a process of text pronounciation, the oratory speech draws a direct analogy to musical interpretation. Contemporary writers of oratory consider that «the most important is the fifth stage of the oratory activity, which is the making a speech ... At this stage, the speaker should best present the result of his work to the audience performed in the previous stages. In other words, one can write a variety of texts very well, but not be able to present them to the audience.

The important predisposition of the use of rhetorical principles in relation to performing, particularly in playing the domra, is stating the exceptional role of non-verbal means on the stage of Pronuntatio, that is, those funds that constitute the essence of the musical interpretation, those that convey to the listener the text of a musical work through individually selected techniques. They correspond with those components which are defined as "verbal unit" in oratory. "The signs of non-verbal communication include the language of gestures and postures; language expressions; paraverbal characteristics; language space; language of clothes and the language of colors etc.» ${ }^{7}$.

7 Колотілова Н. Риторика: навч. посібник. К.: Центр учбової літератури, 2007. C. 113. 
The rhetorical foundations of the European art of professionalism and musical performance in particular is historically visualized: it is the sphere of sacred music that became the main centre enhancement and conservation, the incentive for professional musicians. However, the historical context of the oratory ascents to a leading position in the musical art of Renaissance and Post-Renaissance art space being a Testament to the specific needs of the rhetorical affirmation of art in the background of the musical germs of secularization. The primary symbols of thinking like abstraction, circles, arcs, lines have obtained the basic position $^{8}$ and they note the possibility of the melodic heterophony expression.

The embodiment of the ideal essence of music is the Pythagorean table of altitudes of diatonics, in which the celestial perfect representations and «elements» (water-fire-air) of «rarefied matter» are the worthy incarnations in music: «diapason spiritus» (abc), «diapason medium» (d), «Diapason materialis» (ef). The above demonstrates «musical metaphysics», abstract expressiveness as the bearer of «aboveground joys». Any «approach to the earth» in music required a «divergence» of representation, similar to the fluidity of the material manifestations of the «elements». According to the latter, the most significant symbolic figures of rhetorical presentation, as shown in O. Zakharova's book, are: «rotacio» - rotation, circle, «suspirio» «breath», arc, «anabasis-catabasis», the ascending and descending line, also contain the figure of «fuga» or «running», that is, «movingspreading» altitude at different levels of «conditional space» of music.

In these gradations of the oratory symbolism, the levels of spiritusmedium-materialis are recognizable: the circles or arcs are the symbols of Everything, God, the lines are the «borders» of the worlds, the fugue is the "element of tone», whose «melodic energy» of movement «moves» in the artificiality of the music space. However, these basic and «elementary» figures of musical rhetoric do not form the essence of the possibilities of the «art of speech»: the specifics of the subject semantics of verbal speech, its ability to involve in the visual representations or images testify to the specifics of the oratory deployment in music.

F. Chivra's book directly emphasizes that the very polemicy of humanism against the abstraction of the logical school and the strictly

${ }^{8}$ Гудман Ф. Магические символы. М: Издат.Ассоц.Духовного объединения «Золотой век», 1995. С. 25-28. 
spiritual status of the music law is put forward by an «alternative to rhetoric» as a «science of language,» immersed «in the variety» of «dimensions and qualities of real» dimensions and qualities. The historical projection draws to the identification of poetics and oratory that comes from Plato and Aristotle to Campanella, pointing to the organism of the presence of philosophical knowledge in poetics, especially in sophistry ${ }^{9}$.

The central position in oratory belongs to Elocutio as the doctrine of verbal figures, the techniques of the tropes, that is the verbal combinations or carriers of the super-verbal semantics «colorita», «ornata», «fiorita» ${ }^{10}$. These general provisions of oratory are given here for the sake of accentuating the poetic load of language art, which determines the historical regularity of replacing rhetoric with poetics as a specifically artistic sphere.

As S. Ship correctly points out about the dangers without critical use of the oratory categories in musicology and interpretation, the category of musical oratory must first and foremost be consistent with theoretical ideas about musical language. The concept of rhetoric is meaningful only if it is clearly distinguished from the concept of language. Speech is subordinated primarily to language, i.e. the laws and norms of phonology, morphology, word formation, and syntax. It is expedient to consider the oratory only as a tier of organization of form and content that «builds» over the linguistic order of speech» ${ }^{11}$.

Moreover, the scientist puts forward a number of necessary requirements for the use of rhetorical categorical apparatus for musical artifacts by modern researchers: «The hermeneutical application of the doctrine of the musical oratory requires a specialist: a) the inferior knowledge of the primary sources, the texts that represent this doctrine; b) the systematic theoretical understanding of the linguistic and compositional construction of artifacts of the music speech; c) the art of

${ }^{9}$ Civra F. Musica poetica. Introduzione alla retorica musikale. Torino: UTET Liberia, 1991. C. 19-21.

${ }^{10}$ Civra F. Musica poetica. Introduzione alla retorica musikale. Torino: UTET Liberia, 1991. С. 36.

11 Шип С. Методологическое значение доктрины о музыкальной риторике в немецком и украинском музыкознании (Methodologische Bedeutung der Doktrin von der musikalischen Rhetorik). Музикознавство у діалозі (Musikwissenschaft im Dialog) / Київьке музикознавство (Kiewer Beitrage zur Musikwissenschaft). Київ - Dusseldorf, 2011. Вип. 37. С. 36. 
conceptual interpretation of music, and in particular, a deep understanding of the meaning of musical forms and a sense of balance in expressions" $"$.

The definitions of oratory, both as science and as art, and especially the considerations concerning the peculiarities of the use of the categorical apparatus of oratory in the analysis of musical artifacts, assure that the oratory terminology, as well as the approaches formed by it, should be used with great care and thought. S.Ship's warning against the thoughtless application of rhetorical terms to any arbitrarily choice of musical expressive reception or rhythm and intonation is quite reasonable. The categorical apparatus of the oratory can only be applied within strictly appropriate frameworks of analysis of styles and genres. On the other hand, the methodology of musicological analysis, based on rhetorical approaches, gives convincing results and allows to reveal some deep layers of content and logical mechanisms of construction of the work.

In a study dedicated to the performer's interaction with the modern process of professionalization and academization of the art of playing the domra, the oratory categories seem appropriate to justify the basic provisions. However, from all the diversity of rhetorical components that have been formed and theoretically decommissioned in the musicalaesthetic heritage over several centuries, only some of the most convincing and necessary are selected.

They are:

- the invention as a fundamental impulse of the creative process of both composer and performance; it involves a preliminary perfect (that is, centered in the ideal design of the composer or performer) model that will consistently be embodied in a fixed musical text or performance concept;

- the concept of rhetorical disposition as a structure-forming principle that ensures the logic and integrity of musical construction (according to the above interpretation of this special section of rhetorical science, aimed primarily at the correct organization of the text, ensuring the flawless logic of its composition);

12 Шип С. Методологическое значение доктрины о музыкальной риторике в немецком и украинском музыкознании (Methodologische Bedeutung der Doktrin von der musikalischen Rhetorik). Музикознавство у діалозі (Musikwissenschaft im Dialog) / Київьке музикознавство (Kiewer Beitrage zur Musikwissenschaft). Київ - Dusseldorf, 2011. Вип. 37. С. 42. 
- transfer of the rhetorical component of the correct composition to the composing and performing process in the art of domra play, as it provides an individually creative component of the text construction («the content of speech is included in the paralogy, which allows the use of words and expressions in a figurative sense») and even more so it seems natural and necessary in the compositional principles of artistic (including musical) artifacts;

- taking into account all the wealth of the non-verbal complex of the rhetorical element of «action - Pronuntiatio» in the sphere of interpretation as one of the fundamental ones in the formation and theoretical awareness of the rhetorical load of certain performing techniques of playing at home.

As we can see, from the whole oratory compendium, the concepts that characterize the logical arrangement of the elements of construction and relate to the oratory load of the techniques of playing domra, are involved in the categorical apparatus of the dissertation. Their use seem necessary due to the fact that the incorporation of the oratory principles into the logical laws of constructing a piece of music both fixed (composer level) and sounding (performing level) are formed since the Renaissance and Baroque times. Therefore, their use in home-grown art and performance confirms the tendency to professionalize and academize the folk instrument.

\section{The impact of rhetorical forms on the development of the performing arts of domra}

In this study, we must follow the rhetorical foundations of the instrumental thinking of the domra players, which by virtue of certain historical conditions have preserved the continuity of the performing and composing activities that were mediated in the field of other academic instruments by a narrow specialization of civilization. Although much of the great composer's discoveries were made by the efforts of the artists who combined the skills of a composer and a congenial performing activity, those names are too well known to be repeated. Nevertheless, the classical music of the $18^{\text {th }}$ and $19^{\text {th }}$ century aimed to determine the prevailing significance of the composer's own.

Comparing the above historical information, the following preliminary conclusions are drawn:

1) the slaughtering in Russia was organically connected with the traditions of the ancient Christian church, marked by special religious 
ideas of the Cyril and Methodius tradition, the expression of which is found in the frescas of Sofia in Kyiv;

2) the relation between skomorokhs and the pan-European tradition of highly professional training of Christian bards, formed in the conditions of the early Cossack era within the Lithuanian-Kyiv statehood of the XIII-XIV House of Music.

3 ) the string-plucking performance of the skomorokhs in the context of connection with the early Christianity, is perceived as being in harmony with the traditions of spiritual music, in contrast to the later setting of Orthodoxy (and Catholicism in the period of counterreformation) to the profane the nature of instrumentalism;

4) the historical intertwining of the socially religious and politically religious foundations of life and musical creativity in Ukraine, where the rhetoric of instrumental art, which territorially imitated the skills and abilities formed in Kievan Rus, formed the educational basis of the selfaffirming activity of the nation.

It is known that the adoption of Christianity by Byzantium advanced the very beauty of Divine Service, especially church singing, the perfection of which was the pledge of the attachment of human essence to Heaven, to the Divine essence. Here again we notice the importance of the early Christian tradition, the polyphonic singing of the Irish monks who baptized Russia ${ }^{13}$ ). Church Fathers, Rhetoricians and Gymnasts Andrey Crete, John Damaskin, John Chrysostom and others in the purity of the musical expression of the syllabic verse and its intonation inspired embodiment in the singing of hymns saw the essence of the manifestation of the Christian mood of the soul. And if the Law of God first formed the Word, and the clarity of the verbal presentation of the text was and remains the basis in the Orthodox Christian singing, then its musical embodiment has always been an integral part of this verbal form as a sign of inspiration, the superstitious expression of everyday speech.

The rhetoric of reading of sacred texts begins with the subtlety of its sounding, and the psalmodic reading of such a text by the very subtlety of sound saturated with an attachment to the Supreme. For that there is the supernatural tonaliaty that deliberately distanced such a sound from the vital «sonar filling» that forms the basis of the religious symbolization of what the text proclaims.

13 Лихачева В. Искусство Византии IV-XV веков. Л.: Искусство, 1986. С. 29. 
The oratory ornaments of the sacred text, laid down by the practice of hymn singing, which distinguished the Eastern Church tradition from the prose of rationalized liturgical activity in the West, were the signs of involvement in the Supreme. This adornment of the word (not in the literal sense), added precisely by the music, its tone, eventually gave birth to a church «aria» that preceded the opera and testified to the superstitious inspiration of reading and singing verbal, poetic lines. After all, the first troparians emerged from the free poetic translation of biblical images, forming the tradition of the Christian East, while the introduction of tropes into the Western Church, stimulated by the heirs of Byzantium in the St. Gallen Monastery, was the starting point for the development of artistic ornament in the church singing.

The very beginnings of the composition, that is the elements of the composer's work, stood out in the process of trapping, because by composing verses for established alleluia chants in the Western Christian version, or forming condos from a set of verses in the Orthodox tradition, the singers built a form different from the original one.

The rhetorical principle of composition began with a «rhetorical emphasis» by musical means, which is a repetition of meaningful turnover, that gave the effect of «fugue» in a polyphonic texture ${ }^{14}$. One way or another, the musical outputs in the presentation of the text in the process of liturgy performed and still perform an independent important meaningful function. Although it is an «elementary» (in terms of artistic possibilities of imitation of life sound expression) psalmization, it is the embodiment of the high sense of the One as a manifestation of the high capacity of the ideal intellectual tension of the energy of thinking, which exists outside the defined world of facts and concepts.

The author of the book "Myth and Ritual in Christianity" A. Watts notes the following: "since the time of Hilbert, mathematicians have no longer attempted to define the point". Specifying the depth of the paradox of our conceptions of knowledge, he adds: «Modern science has resigned itself to the fact that it has to operate alongside fundamental, unknown, marked concepts without precise definitions ${ }^{15}$.

In the symbolic dimensions of the world of religion and art, «point» is a factor of the utmost importance of expression: for «a graphically

${ }^{14}$ Civra F. Musica poetica. Introduzione alla retorica musikale. Torino: UTET Liberia, 1991. C.42.

15 Уотс А. Миф и ритуал в христианстве. К.-М.: София, 2003. С. 66. 
represented circle with a dot in the center indicates the center of the infinite or the root cause» ${ }^{16}$. And if in the art of painting there is a legend about the «points» displayed by the hand of a master on a portrait sketch of a student who made the last imprint of living eyes, then the basic reality of this art of painting becomes a line as a set of points. And in music the self-importance of tone-point as the center of expression of musical essence is evident from the «primitive» of the studios to the virtuoso skills of «taking» the inaccessible notes of the composite whole.

Considering the myth a true «revelation of the power of the Lord» ${ }^{17}$, and religious Christian doctrines by the union of mythology and science. «... Christian dogma is a mixture of ancient Jewish mythology and history with Greek metaphysics and science ...» ${ }^{18}$, A. Watts considers «poetry and myths» the embodiment of the «real world», in contrast to the «dead world» of what was or will be, that is, the world of scientific factology. The reality of the «miracle of music», a mystical phenomenon centered on singing, but based on an instrumental start. And the latter embodies an outlet for the «natural» speech range, as Isidor Seville noted $^{19}$.

In this connection it becomes clear, and the caution with which the Orthodox thinker, the representative of musicological science Martynov speaks about the difference of the linear «delicacy» and nevma marked «phonemes» of ancient Church music. The victory of the all-sufficient physical power is manifested in tone and originates in the depths of the European Renaissance materialist world, in which physical reality is the criterion of truth and life reliability. And on this wave of growing of nationalist materialistic culture breakthrough stringed instruments approved «recast» human detection in the world, pushing the symbolism of a plucked sound with its delicate «touch» to the altitude that continues with the sound quality of the rehearsal efforts in tramelan.

Sound became the basis of mundane and profane music and the evaluation of it has found the subject material sense which is different from the ideal abstraction of sacred and Church music. For a professional musician the sound became a way of artistic communication, from what a «bad» sound is aesthetically obliged by the incompleteness of the

${ }^{16}$ Большая энциклопедия символов и знаков / Сост. А. Егазаров. М.: АСТ, 2007. C. 676.

17 Уотс А. Миф и ритуал в христианстве. К.-М.: София, 2003. С. 72.

18 Уотс А. Миф и ритуал в христианстве. К.-М.: София, 2003. С. 65.

19 Уотс А. Миф и ритуал в христианстве. К.-М.: София, 2003. С. 26. 
artistic ideal performance. Many instruments sound «ready» (piano, accordion...), while the other instrumental conditions (to a large extent and the sound of the domra) the sound generated by the contractor and intonation, and linguistic and sobralinho subject. But even in the case of direct dependence of instrumental intonation, the quality of instrument (Bayan-accordion, for example) the sound quality depends on the ability of a performer to «pull it out», but on the domra this is the basis of music performance. Therefore, clearly recognised the «success story» by the domra as a result of a lot of care and interest of the contractor in the produced sound.

The quality of sound is determined by its timbre, and the nature of the latter depends on one or another overtone, as well as on the strength of its detection, when it comes to the post-Renaissance stage of the formation of music as «sound-painting art», the art of «harmonious expressiveness») of sound (overtones are the analogous to perspective in painting).

In line with this concept of parallels of music and fine arts has been studied by many scientists, including this study by G. Helmholtz and K. Stumpf. Pointing to overtones as the cause of timbre, according to G. Helmholtz, we make the following conclusions:

- The overtone scale from the first to the sixth is the main basis of musical sonority and timbre;

- Overtones above the sixth give sharpness and hardness to the sound;

According to the conclusions of K. Stumpf, the dependence of the timbre on the overtones is explained as follows: by the coloring, the steps of the overtone scale move from a thick, filled color to a transparent and light color, from the darkest to the brightest. Consequently, the coloration of a sound consists of the coloration of its tones, and the accompanying noises greatly affect the purity of the timbre resulting from the overtones.

Thus, deliberately altering the conditions that determine the overtone structure of the sound, by academic school, as it now is by domra, actually controls the sound quality, which is obtained on the instrument. But a good, clean sound is not the only task. Art also requires a great variety of shades of the sound including their ideal «resembalnce» that reduces to the Genesis of plucked instruments. In this case, we are approaching the musical «mythologism», sonically fleshing out the impossible and the unknowable. 
To the X-XI century in the Celtic countries there has been established the role of the bard as a carrier of folk performing traditions, the Keeper of traditions and folk wisdom. Bards created a special layer of the artistic society, independent in a certain sense. No event in the life of the people or in the life of an individual is complete without their participation, whether it is war, feast, wedding or funeral.

The bandore sound of the XV-XVII centuries was marked not as directly by the «revival of antiquity» as by the harmony of anti-Christian and Christian religiosity that occurred in early Christianity (the era of «musical revival» by K. Kuznetsov ${ }^{20}$ ) and was rejected by the iconoclastic rigorism. The Middle Ages culture also acted as a viable alternative to the Renaissance renewal, beginning with the Carolingian and Macedonian Renaissance of the VIII-XII and IX-XIII centuries ${ }^{21,22}$. After the anti-religious and anti-Church orientation of scientific and artistic activity of the New time the end of XIX century demonstrated the revival of the harmony in the creative and religious spheres, which was most clearly expressed by the symbolic theorist A. Bergson ${ }^{23}$, pointing to the identity of the method of art and religion.

The action of V. Andreev, carried out with the help of the Ukrainian cultural aura under the real conditions of his activity, gave life to the academic domra music. It took place in the context of the symbolic achievements of the «Silver Age» (1888-1896), reproducing in the orchestra's structure as a symbol of victorious European musical academy, the sound of fundamentally non-orchestral, namely, ensemble «replacement singing» instruments, which by its nature was Renaissance music.

If one accepts that the idea widespread in contemporary cultural studies and the anthropology of music, saying that "the frameworks within which the music system change takes place depending on the sociocultural environment. This observation is true even where the music

20 Кузнецов Б. Путешествие через эпохи. Мемуары графа Калиостри и записи его бесед с Аристотелем, Данте, Пушкиным, Эйнштейном и многими другими современниками. М.: Молодая гвардия, 1976. С. 40.

21 Каролингское возрождение [Электронный ресурс]. Режим доступа: https://ru.wikipedia.org/wiki/Каролингское возрождение

22 Лихачева В. Искусство Византии IV-XV веков. Л.: Искусство, 1986. C. 99-133.

${ }^{23}$ История философии: в 4-х томах / Под ред. М.А. Дынника, М. Иовчука и др. М.: Изд. АН СССР, 1957. Т. 1. 1957. С. 715-716. 
is sought to be regarded as an autonomous entity" 24 , some of the cultural and historical changes occurring in the spread of domra and other instruments of this group become quite clear. The «pointilistic» nature of sound on stringed pluckers in the Andreev Orchestra corresponded to the pointilist findings in the painting at the beginning of the 19th and 20th centuries (J. Sora, P. Sinyak) and the attempts of A. Webern's musical pointillism, as well as the psychological-pointillist view of the world as a series of «sensations» in the influential E. Mach University philosophical neo-positivist concept. And similarly to how the painting of postimpressionism and symbolism made sense of the appeal to the reviving values of icon painting and the mosaic art related to it, so in the musical sphere of the 19th-early 20th centuries. There was an appeal to Schola cantorum in France, to the vocal polyphony in S. Taneyev and M. Leontovich in Russia and Ukraine, to the pre-Peter music, which included Ukrainian-Cossack artistic heritage, which obviously inspired V. Andreev.

It makes an inevitable conclusion that the symbolic nature of the old tools, is fundamentally different from the intelligible «anthropocentric» music of the New time. Above the genre system of the last century is characterized in accordance with the archetypology of the structure of mass in their semantic direction to the orchestra sound. In this typological load the duality of values has been expressed: the inclination to ecclesiastic genres, but with demonstrative opening of their liturgical content. This «Neorenaissance» worldview is different from goal setting the Creator of the «orchestra of folk instruments»: on the one hand, demonstrative preserving the purity of the folk tradition, on the other hand, the voluntaristic creation of the team of specialists, training testified about his involvement in the academy.

The paradox of a thought by A. Watts about the «reality» of myth and «dead» in the generalizations of matter allows us to understand the significance of the musical component in human expression, even if it is only one pitch in the psalmodic representation of the text. Incarnation in tonal dimensions of «things» and «facts» of what is called «reality», and Watts identifies as «the dead world», in musical and artistic expression gives the perfect combination of «living» and «dead», real instant and accrediting conceptual integrity of the tone of one or another image.

${ }^{24}$ Dobberstein M. Musik und Mensch. Grundlegung einer Anthropologie der Musik. Berlin: Dietrich Reiner Verlag, 2000. C. 13. 
Born with effort due to V. Andreev, the orchestra of folk academic instruments, responding to the demands and urges of the time, found itself in the situation of the heir to the orchestral traditions of Greece and the Italian South, that is, it was the representative of the polar opposite tradition to the most widespread and glorified European music at that time.

This reasoning focuses on the «elementary oratory» of sound production performed on a specific instrument, followed by the pathos of the oratory presentation of sound which is imparted by the material character of the material from which the instrument is built. Hence the «vitality» of strings of the instruments of ancient ritual, since the strings resembled the nerves, the body, the human body, and the correct mood of the strings symbolized the harmony of the soul and body of human creation $^{25}$.

The basis of the artistic approach of the authors of Antiquity was the idea of «mimesis», i.e., «imitation», which occured in post-Renaissance European conception of realism in art: «imitation of life», «the second reality» as «assimilation» to recove reality of the human environment and that the material-spiritual nature of human kind.

If the first side of the mimetic activities are usually distinguished terminologically speaking about realism in artistry, then the second is associated with the beginning of symbolic thinking and art. Moreover, this symbolic side of mimetic activity was for the ancient Greek philosopher of the base that forms the Foundation of mental activity in General, and in her music it was the «trigger». This is determined solely by the responsible function of music and music education in society: «music being the gymnastics of the soul», «music as gymnastics of the intellect» as a logically and intellectually created the leading sign of the ancient «soul» that harmonizes with the body ${ }^{26}$.

The basis of this mental setup is the Church's symbolic worldview, giving rise to an oratory model, significantly different from the verbal rhetorical principles of Antiquity, designed to develop a hierarchy of affects.

25 Холл М. Энциклопедическое изложение масонской, герметической, каббалистической и розенкрейцеровской философии. М.: Эксмо; СПб.: Мидгард, 2007. С. 72-74.

${ }^{26}$ Музична естетика Античної Греції. Вступний нарис $i$ зібрання текстів О.Ф. Лосєва. К.: Музична Україна, 1972. С. 18-36. 


\section{CONCLUSIONS}

The symbolism of «the imitation of ideas» was adopted in the numerical concept of the world of Harmony, which in ancient philosophy was formulated by Pythagoras. In this field he laid the foundations of metaphysics, i.e. teaching about the obvious signs of unchanged integrity of the world and continualist thoughts. The projection of the mentioned positions in the plane of instrumental music provides the differentiation types of tools to those that are primarily associated with the material integrity of the world, and those that are able to convey the spontaneity continuum of thought. As for the tempo-virtuoso range of the string group, he definitely belongs to the second group and, as shown in the previous subsections can understand rhetorical elements of the speech origin. It is known that musical rhetoric refers to almost all genres and forms, as vocal and choral, theatrical, and instrumental. But the plucked string group, including domra as one of its characteristic tools reports the rhetorical techniques in a very indirect way, in the conventional plane ideal image.

Domra, having enterecd the field of academic instrumental performance relatively late, has kept the tradition of the unity of the «composer-performer» much more than other academic tools. This is due to the lack of respectable academic repertoire for domra and the entrenched practice of performance, which provides in its art the result of improvisation, spontaneous component, the need to add something from himself» to famous works already in the process of interpretation.

This seems to be the preservation of the syncretic traditions of musical art that has existed for many centuries and only relatively recently has lost its relevance, giving way to a differentiation of creative activity of the composer, performer and teacher.

A historical and stylistic discourse of creativity for the mandolin, which we interpret as the tool is fundamentally intertwined with the domra in Western timbre compendium, as well as for the dobro in a chronological interval from the XVIII to the XXI century. The Mandolin, which is very diverse, given its rich imagery and emotional and expressive features is used by the composers of the past and present from A. Vivaldi to M. Skoryk, by its nature, detects close to domra, particularly with regard to rhetorical speech virtuost characteristic of both tools and techniques.

Domra, which was prevalent in musical practice, mainly on the wave of symbolism of the Silver Age in the Russian culture during the centuries of its intensive development course combined the academic 
trend that some previously put on the mandolin with the folk origin, but has not lost the characteristics of national instruments, sensitive to the innovative stylistic trends to be active in search of innovation, and experimental for the 21 century $^{27}$.

\section{REFERENCES}

1. Большая энциклопедия символов и знаков / Сост. А. Егазаров. M.: АCT, 2007. $723 \mathrm{c}$.

2. Бондаренко В. Риторика. Харків: Вид-во ХНАДУ, 2008. 121 с.

3. Гудман Ф. Магические символы. М: Издат. Ассоц. Духовного объединения «Золотой век», 1995. 289 с.

4. Захарова О. Риторика и западноевропейская музыка XVII первой половины XVIII века. М., 1983. 77 с.

5. История философии: в 4-х томах / Под ред. М.А. Дынника, М. Иовчука и др. М.: Изд. АН СССР, 1957. Т.1. 1957. 717 с.

6. Каролингское возрождение [Электронный ресурс]. Режим доступа : https://ru.wikipedia.org/wiki/Каролингское возрождение

7. Колотілова Н. Риторика: навч. посібник. К.: Центр учбової літератури, 2007. 232 с.

8. Кузнецов Б. Путешествие через эпохи. Мемуары графа Калиостри и записи его бесед с Аристотелем, Данте, Пушкиным, Эйнштейном и многими другими современниками. М.: Молодая гвардия, 1976. 190 с.

9. Лихачева В. Искусство Византии IV-XV веков. Л.: Искусство, 1986. $310 \mathrm{c}$.

10. Маркова Е. Неоевропоцентризм и неосимволизм начала XXI века. В. Холопова, Л. Канарис, Е. Маркова, С. Таранец. Неоевропочентризм: музыкальная культура на рубеже столетий. Книга 1. Одесса: Астропринт, 2006. С. 76-128.

11. Мацько Л. Риторика: навч. посіб. 2-ге вид., стер. К.: Вища школа, 2006. $311 \mathrm{c}$.

12. Музична естетика Античної Греції. Вступний нарис $i$ зібрання текстів О.Ф. Лосєва. К.: Музична Україна, 1972. 322 с.

27 Маркова Е. Неоевропоцентризм и неосимволизм начала XXI века. В. Холопова, Л. Канарис, Е. Маркова, С. Таранеи. Неоевропочентризм: музыкальная культура на рубеже столетий. Книга 1. Одесса: Астропринт, 2006. C. 76-128. 
13.Покровская Н. История исполнительства на арфе: Курс лекций [для оркестровых факультетов (струнное отделение) музыкальных вузов]. Новосибирск, 1994. 351 с.

14.Уотс А. Миф и ритуал в христианстве. К.-М.: София, 2003. $240 \mathrm{c}$.

15.Холл М. Энциклопедическое изложение масонской, герметической, каббалистической и розенкрейцеровской философии. М.: Эксмо; СПб.: Мидгард, 2007. 864 с.

16. Холопова В. Музыка как вид искусства. М.: Научно-творч. центр «Консерватрия», 1994. 260 с.

17.Шип С. Методологическое значение доктрины о музыкальной риторике в немецком и украинском музыкознании (Methodologische Bedeutung der Doktrin von der musikalischen Rhetorik). Музикознавство у діалозі (Musikwissenschaft im Dialog) / Київське музикознавство (Kiewer Beitrage zur Musikwissenschaft). Київ Dusseldorf, 2011. Вип. 37. С. 23-49.

18. Civra F. Musica poetica. Introduzione alla retorica musikale. Torino: UTET Liberia, 1991. 215 p.

19.Dobberstein M. Musik und Mensch. Grundlegung einer Anthropologie der Musik. Berlin: Dietrich Reiner Verlag, 2000. 150 s.

Information about the author: Oliinyk O. L., Rector, Ph.D. in History of Arts, Professor at the Department of Folk Instruments, Odessa National A. V. Nezhdanova Academy of Music 63, Novoselskogo str., Odessa, 65023, Ukraine 
DOI https://doi.org/10.36059/978-966-397-201-5/93-112

\section{POLYSTYLISTICS AS A MUSICAL PHENOMENON AND ITS AUTHOR'S MODELS}

\section{Grybynenko Ju. 0.}

\section{INTRODUCTION}

The XX century, ending and moving towards the third millennium, performs a difficult task. On the one hand, it is an extension of cognition methods (both in science and in art) associated with the desire to cover many information flows; on the other, it is an already completed transition to a new millennium and readiness for it, and hence the increased role of psychological knowledge, designed to explain the future possibilities of the evolution of human consciousness - as its possibility for life in the future.

Transformation on the new basis of leading ideas of the past has always been one of the main links in the artistic and aesthetic process. The phenomena that arise on the border of continuity and innovation actively influence the development of any direction in art. In the XX century, these phenomena in the context of new style searches are developing widely and in diverse ways. Some of them have long been entrenched in composer's practice, but even today they continue to remain insufficiently studied. Therefore, the identification and analysis of style trends diversity in composer's creative work in the second half of the XX and the beginning of the XXI centuries is becoming especially relevant for modern musicology. It is known that this period in art does not represent a single historical style. It is formed by various trends and directions, what gives reason to talk about the "pluralism" of musical culture in these decades, about the complex stylistic conglomerate of this era; the desire for stylistic universality seems to be one of the most important stylistic aspects of the art of this period as a whole.

In music today there is a process of synthesizing, summarizing previously found genre and style realities; in the compositionally unified the different (according to the linguistic possibilities of music) combines, and in various stylistic tendencies a new desire for methodological unity is manifested. As a historical phenomenon, at the beginning of the XX century the musical and creative process is at the final stage summing up results, so far without a clear anticipation of fundamental 
changes. However, it is from the side of the individual composer's style that the new essential properties of artistic synthesis appear, leading to the polysystem of musical thinking and openness not only of compositional (as P. Boulez interpreted it), but also of the stylistic form of music. As a result of this, associative independence, figurative and semantic initiative of the author's style, based on the variety of style interaction forms, is increasing.

The composer's work of the second half of the XX century and the beginning of the XXI centuries is largely aimed at integrating a wide genre and style spectrum of musical layers of the most diverse eras. M. Aranovsky, pointing out this quality of modern composer's poetics, emphasized that fragments of styles in the process of creating a musical composition fulfill the functions of components with a "set value", which opens up the possibility for the composer to operate with them as with signs. At the same time, "the entire stylistic spectrum of the history of European music becomes the subject of artistic reflection" from the side of the author ${ }^{1}$, as a result of which the "stylistic layering" of the text is formed. In domestic and foreign academic music of the indicated period, this tendency is embodied in the method of polystylistics - a symbolic expression of the multiplicity of musical consciousness, a leading composer's method that meets the author's conscious intention to introduce his design into the general style context of music.

\section{Polystylistics in the light of musicological reflections}

The musical and artistic phenomenon - polystylistics, which introduced new historical and cultural dimensions and its artistic possibilities into music, - causes active discussions up to this day. The appearance of this term is legitimate and necessary, since in the last decades of the XX century polystylistics took shape in a conscious manner, established itself as a stylistic multiplicity, complexity, internal contrast of one composition, that is, as a compositional phenomenon. In this regard, it is interesting to compare the phenomenon of polystylistics with the "two-voiced word" in its coverage by M. Bakhtin. As a kind of author's utterance, such a "word" reflects the author's ability to use alien word for his own purposes, to invest a new semantic orientation in the "word", which already has its own orientation and preserves it.

1 Арановский М. Музыкальный текст: структура и свойства. М., 1998. C. $157-159$. 
Moreover, such a word, according to an assignment, should be felt like alien. Of particular interest in this connection is "hidden polemic: "alien word" is repelled, and this repulsion is not less than the very subject in question defines the author's word",2. Hidden polemics is sometimes unusually vividly reflected in music, when the element of reaction to the previous style, present in each new style, is the same internal polemic, so to say, a hidden anti-stylization of alien style, often combined with mimicking it. Polystylistics as a kind of protest against the thoughtless assimilation of traditions owes this to polemic with tradition.

If since the $60 \mathrm{~s}$ of the XX century, the time of the polystylistic "explosion", the main goal in comprehending the phenomenon has been the study of musical "matter" (qualities and levels of assimilation of borrowed material), then the most relevant is the in-depth study of the semantic content of polystylistics, the search for those aspects that will help to comprehend the stylistic essence of modern musical culture, as well as to reveal in the principles of variability of the "alien text" the influence of some general cultural trends.

$\mathrm{V}$. Kholopova notes that European culture of the XX century is notable for its severe breakdown into many isolated subcultures. In parallel and independently from each other, according to the author, there is a classical heritage of different eras, avant-garde experimentation, jazz, pop and rock music, pop music, European folklore, cult music, mass songs, electronic and specific music, traditional music of non-European countries, etc. "At the same time, the avant-garde, which had completely dried itself out in a pointillistic («point») style, and the stage-jazz style, unchained to a physical gesture, made up mutually exclusive poles of culture" 3 .

Similar situations of gaps in culture arose in the past, and not only in music. According to literary scholars, the position of the verbal language in Russia in the first decades of the XIX century, when there was a language of fiction, colloquial, clerical, military languages, the language of theological literature, etc., but no single Russian language, could serve as an analogy. This state of the language created many obstacles to the development of Russian society, its thinking. The writer who combined all these languages was N.V. Gogol. Gogol's literary and linguistic

2 Бахтин М. Собрание сочинений в семи томах. Проблемы поэтики Достоевского. Том 6. М.: Русские словари, 2002. С. 219.

${ }^{3}$ Холопова В. Композитор Альфред Шнитке. Челябинск: «Аркаим», 2001. C. 90 . 
reform had an enormous progressive social meaning. And in terms of art, the language of the great writer revealed the inexhaustible resources of the play with stylistic components - speech stylistic layers, that is, the resources of verbal and language polystylistics ${ }^{4}$.

The source of musical polystylistics can be considered the "one-time contrast technique", which, having established itself in the music of J.S. Bach, becomes one of the most important principles of style formation in the future history of music. The term "one-time contrast", proposed by T. Livanova, is interpreted by E. Nazaikinsky as "something complex, mediated by physiology, psychology, culture and, at the same time, directly infecting, involving in empathy, cathartic state"5. The author emphasizes that "this is not a contrast in the literal sense of the word. There are no sharply delimited and disjoint planes, there are no parallel, but different in character and sound properties components of the texture ..." And if they are, then most often they are not perceived as opposing, since they are subordinate to the unity of harmonious, rhythmic, textured organizations. The special nature of the relationship of the contrasting parties cannot be unambiguously defined by the concept of coordination or subordination; here is more likely a single combat, an inextricable interweaving of hostile forces, which is not so much perceived as directly experienced. "The "contrast" here is a metaphor"; "Forces ... engage in a battle that engenders a static but tense expression observed from the outside" .

A specific feature of modern musical culture is the oncoming movement of composer's and musicology thought in search for new nominations of composer's poetics. Quite often, it is in the field of compositing judgments that promising theoretical positions are formed, since composer's consciousness feels the need for self-determination in theoretical assessment. A vivid example of what has been said is Alfred Schnittke's report, "Polystylistic Trends in Contemporary Music", made at the MMS congress on October 8,1971, in which the concept and term "polystylistics" were first declared by the theoretic and composer and two polar principles of using "alien style" were outlined: the principle of

\footnotetext{
${ }^{4}$ Там же.

5 Назайкинский Е. Принцип единовременного контраста. Русская книга о Бахе. М.: Музыка, 1985. С. 277.

6 Там же, С. 275.

7 Там же, С. 275.
} 
citation and the principle of allusion ${ }^{8}$. The composer, in the compositions of whom there are a lot of different stylistic innovations, turning to the music of other masters, builds a theoretical base for his own creative finds. He introduces the terms polystylistics, allusion, adaptation, considers the concepts of collage, quotation, citation, and parses a number of musical samples. E. Nazaykinsky focuses on the fact that at first glance, it may seem that the definition of polystylistics by A. Schnitke is only a peripheral of philological interpretations of stylistics - a well-known and approved term. Indeed, the style of the work reflects the use of several different style components in its compositional and semantic structure. And the Greek prefix of the term (poly-) introduced by A. Schnittke just indicates their multiplicity. But is this indication really necessary? Indeed, monostylistics does not exist in real artistic practice. Polystylistics is a necessary "nutrient" medium of music of any era. The composer himself justifies the feasibility of introducing a new term, treating polystylistics as a special type of style, raised in the $\mathrm{XX}$ century to the level of leading compositional technique ${ }^{9}$.

Alfred Schnittke asks the question: "... Is the word "polystylistics" acceptable in relation to the elusive play of temporal and spatial associations, inevitably inspired by music? Indeed, in a hidden form, a polystylistic tendency exists and existed in any music, because stylistically sterile music would be dead. So is it worth talking about it? ${ }^{10}$. And he himself answers: "It is necessary to talk about it, because in the last decade the polystylistics has taken shape in a conscious manner without even quoting, the composer plans in advance a polystylistic effect, whether it is the effect of the shock from a collage of musical times, whether it's slipping through the phases of musical history, or the subtlest, as it were, random allusions" $"$.

According to E. Nazaykinsky, the main motive for introducing a new term (polystylistics) was the need for the composer to give a name to the modern stylistic composition technique. As a matter of fact, this technique is not so new; the conscious, purposeful use of complex stylistic comparisons and relationships, of course, was encountered in

${ }^{8}$ Холопова В., Чигарева Е. Альфред Шнитке: Очерк жизни и творчества. М.: Советский композитор, 1990.

${ }^{9}$ Там же.

${ }^{10}$ Там же, С. 329.

${ }^{11}$ Там же, С. 329. 
composer's practice long before the avant-garde artists of the XX century. Perhaps, only a somewhat more intense and sharper handling of the stylistic components of the composition nevertheless gives reason to add to the terms polytonality, polytimberness, polyrhythmia and also polystylistics, characteristic of the era ${ }^{12}$.

The definition of polystylistics in the Encyclopedic Dictionary of Music (1991) introduces another trait that A. Schnittke does not have. This phenomenon is interpreted as "an intentional combination of incompatible (or at least sharply different, heterogeneous) stylistic elements in one composition". It is clear that this definition somewhat changes the content of the concept, limiting polystylistics only to contrasting stylistic elements ${ }^{13}$. After all, A. Schnittke spoke not only about "shock" comparisons, which were especially effective in "gluing" (collage) dissimilar texts, but also about soft allusion, imperceptible stylistic modulations. The main thing for him was to give a name to the special modern compositional technique.

A significant contribution to the development of the problem of polystylistics became the works of G. Grigorieva, in which the musicologist suggested using the term eclecticism (borrowed from architecture), interpreted as a method of active style interactions. The author pointed to the specification of the composer's technique of working with the material as a factor of poly-and monostylistics, as well as the fact that the polystylistic technique follows a rather intensive development path and modulates the new component into monostylistics, where the "musical galaxy" of the attracted material is not aimed at sharpening contrasts, but, on the contrary, at their smoothing ${ }^{14}$.

The works of V. Kholopova are also associated with the development of the theory of polystylistics. The musicologist considers this phenomenon as a method of creativity, determining various types of musical semantics, which, according to $\mathrm{V}$. Kholopova, gives an opportunity, summarizing the multiple semantic data, to distinguish three leading types of polystylistics: diffuse, collage, and pluralistic. The first type, in her opinion, is characterized by a smooth transition from one

12 Назайкинский E. Стилистика музыкального произведения. URL: www.harmony.musigi.dunya.az/harmony/rus

13 Энциклопедический музыкальный словарь. М., Советская энциклопедия, 1990. C. 431.

14 Григорьева Г. Стилевые проблемы русской советской музыки второй половины ХХ века. М., Советский композитор, 1989. 
style element to another, by the stylistic dispersion of the original thematic complex. The second type is characterized by contrast, sometimes a sharp ("shock") juxtaposition of style elements. Pluralistic polystylistics is a new peculiar technique of inconspicuous gradual stylistic modulation, which ultimately leads to the formation of a style that is no alien to any other ${ }^{15}$.

The plurality of attitudes toward polystylistics gives rise to numerous definitions of it. However, despite the difference in approaches, there are common features. The unifying one is the recognition that through polystylistics in a musical text, both old proven techniques and very problematic, "heuristic", new ones are put on one side of the scales. Most of the definitions also generalize the concept of an "alien word". For example, V. Medushevsky presents polystylistics as "a dispersed way of combining different style signs" $"$, V. Syrov - as "assimilating systems, where the stylistic level ... does not reveal a clear division into elements of the main (own) and subordinate (alien)",17. For S. Savenko, it's "an attempt to seriously speak the alien language, destroying any distance both ironic and tragedy"18, and M. Aranovsky defines polystylistics as "a special creative concept of style" based on "the principle of operating styles as elements with established expressiveness" ${ }^{19}$. In other words, the belonging of a sound to one or another style is evaluated as a more significant factor than the properties of the sound itself, because the main bearer of meaning is this or that style as a sign of culture - the "worldview style".

\section{The polystylistic method and contemporary composer's poetry}

The method of polystylistics turned out to be especially in tune with the circle of ideas addressed by major European composers of the 1960s and 80s. One of the most important ideas of this time is a comprehension

15 Холопова В. Музыка как вид искусства. М.: Научно-творческий центр «Консерватория», 1990.

16 Медушевский В. Стиль как семиотический объект. Советская музыка. 1979. № 3. С. 38.

17 Сыров В. О стиле Бориса Тищенко. Проблемы музыки XX века. Горький, 1977. C. 26.

18 Савенко С. Есть ли индивидуальный стиль в музыке поставангарда? Советская музыка.1982, № 5. С. 121.

19 Арановский М. Музыкальный текст: структура и свойства. М., 1998. C. $157-159$. 
of the ethical state of modern culture, and together with culture, the ethical state of modern man. The polystylistic method made it possible to expand the panorama of the musical culture of immense breadth and to make various oppositions in it in an associative way - through style allusions and quotes. Composers introduced all conceivable styles into the composition, practically reaching the exhaustion of all known style representations, at the same time, striving to confirm their author's beginning.

Based on this, we can talk about three trends that are characteristic of contemporary composer's creativity.

The first is the movement of polystylistics towards stylistic synthesis and monostyle, which, in turn, can be considered as a kind of victory of the author's style over Polycentrism of historical musical consciousness. In the XX century, polystylistics is recognized as a universal method of composer's creativity; at the same time, each of the contemporary authors finds his own path to polystylistics, forming special artistic relations with it. Thus, we can say that there are as many types of polystylistics as there are individual composer's styles, given the tendency of the latter (composer's style) towards autonomy.

This trend is confirmed in the work of the Leningrad composer Galina Ustvolskaya, whose creative method does not fit into any of the known definitions of polystylistics and requires the emergence of a new nomination. The student of D. Shostakovich, one of the key figures in Russian music of the second half of XX century, first made herself known in the 1940s and 1950s, and since then her composer's style has hardly evolved.

Ustvolskaya is an unusually solid artist. She is distinguished by its her style, the invariability of the musical language, introspectiveness, total authorization, "warlike rejection" of analogies, heritage and similarities, a focus on deepening the main ideological and style complex, and paradoxical thinking. The last feature of Ustvolskaya deserves special attention, since she is the leader in her composing poetics and manifests herself, first of all, as a combination of stylistic multidimensionality with monolithicity, the internal integrity of the style; rigor, restraint with spiritual nudity, ecstatics of musical utterances; tremendous tension with inner composure; "laconicism" with a depth of ideological content and global themes of the compositions.

One of the most remarkable features of Ustvolskaya's style is that, with his pronounced individuality, even individualistic categorization, many of the characteristic stylistic devices of other authors are reflected 
in the music of the composer. The peculiarity of the dialogue conducted by Ustvolskaya is expressed in the fact that she uses the "alien" as "own", immediately exposing it to deep assimilation. It is not so important for her that she takes many "alien words" from the already existing experience of their interpretation, from the "hands" of any other author. In most cases, Ustvolskaya does not emphasize or conceal the alienness of the borrowed.

As the musical material with which the composer's works, there are stylistic signs of distant eras, as well as authors historically close to Ustvolskaya. In the latter case, dialogic interests acquire an "inter-author character". Thus, we can say that the composer conducts a dialogue in two directions: with the historical style past and with contemporary authors. So, for example, in piano sonatas explicit associations arise with the works of Shostakovich, Hindemith, Bach, Stravinsky. Ustvolskaya relies on polyphonic ways of building text, while achieving constructive rigidity, linearism, graphic clarity of texture.

It is possible to draw parallels between the style installations of Ustvolskaya and Hindemith. Both composers generalize the characteristic genre and stylistic features of the Renaissance and Baroque music, but put them in the context of a modern artistic worldview, subordinate to the personal problems of a person of the XX century. Like Hindemith, Ustvolskaya is attracted to Bach's creativity and, above all, to Bach's melos as distinguished by semantic polyphonicity is the disclosure of the multiplicity of the whole. Prolonged tense ostinato and polyostinato, a tendency to acutely dissonant implementation of folkloric intonations are the confirmation of the Stravinsky language influence.

The characteristic polystylistic techniques in the works of Ustvolskaya include:

- a plurality of stylistic sources, which degenerates into an emphasized unity of stylistics, covering both the conceptual level and internal processes of intonational and stylistic formation;

- a peculiar treatment of the composer with the "alien word", which consists in the fact that for the author it is more important not to belong to the "word", but to its meaning; 
- the principle of genre allegory as the use of the stylistics of specific genres as carriers of semantics - certain signs and, at the same time, the removal from this stylistics ${ }^{20}$.

The second trend is related to the fact that composer's poetics poses broader tasks, primarily related to the artist's new responsibility for his social mission, as a result of which interest in the ethical parameters of composer's poetics is growing. One of the most important ideas of our time is to comprehend the moral state of modern culture, and together with culture - the moral state of modern man.

The polystylistic method made it possible to expand the panorama of the musical culture of immense breadth and to build in it various semantic oppositions in an associative way - through stylistic allusions and quotes. Composers introduced into the composition all the styles known to them, practically reaching the exhaustion of all known (historical and author's) style paradigms.

On the part of the composers themselves, what has been said is connected with the emergence of a new interest in the verbal principle as an internal compositional factor in a musical composition. So, the idea of G. Ustvolskaya, verbally stated by her in the Second and Fourth Symphonies, becomes her peculiar credo, which she follows throughout her life. In both symphonies, religious texts are used in the author's translation, indicating that G. Ustvolskaya is the artist of one idea global, infinite, eternal.

The unity of the theme addressed by the composer in his compositions allows us to consider them as a kind of macrocycle. This is also confirmed by the desire of G. Ustvolskaya for the intonational unity of most of her compositions, sometimes reaching the limit. So, for example, in sonatas one intonation complex is used, consisting of several layers: the first is the incoming movement; the second is the intonation of the descending second, the third is a jump over a wide interval. Thanks to this, all sonatas of G. Ustvolskaya can be considered as a single cycle with a culmination in the Sixth Sonata.

For A. Schnittke, the polystylistic method is associated with the pluralism of human consciousness of the XX century, with an increased intensity of information flows in this century. According to this

${ }^{20}$ Грибиненко Ю. Парадоксы полистилистики в творчестве Г. Уствольской. Научный вестник НМАУ им. П.И. Чайковского. Музичний стиль: теорія, історія, сучасність. Киев, 2004. Вып. 38. С. 220-227. 
composer, the most important thing for polystylistics is the ability to express semantic opposition within the image, create intonational tension, and combine incompatible ones. This leads to a consistent reflection in the composer's music of an expressively tragedy aesthetic sphere based on a personal experience of the paradox of being. The internal tension of the image, focusing on the leading author's intonation, the sharp accentuation of the polar principles (the semantics of positive and negative images are very clear), the special nature of the removal of musical material, which reaches the composer to alienation, deformation, the extreme sharpening of contradictions while using several genre and style complexes (the implementation of the "poetics of conflict"), introducing dramatization as a condition of psychological stress become fundamental features of A. Schnittke creative method of forming a particular type polystylistics.

In addition, the polystylistic method of this author is characterized by the application of genre allegory principle as the use of the stylistics of specific genres as carriers of semantics - certain characters and, at the same time, removal from this stylistics. This is most clearly manifested in the use of one of the key themes of the compositions of A. Schnittke the theme of the circle, which is characterized mainly by second intonations, structural symmetry, and the rotational type of melody. These are the motives: $B A C H$ (First and Second Sonatas for violin and piano) and the perpetum mobile motif (Cello Sonata, First String Quartet), built as a developing spiral, gradually covering a larger and larger range. The coincidence of the figures of the cross and the circle in the BACH motif testifies to the semantic layering of this topic. It is significant that this fact once again reveals to us the dialogical thinking of A. Schnittke. On the one hand, the theme-circle symbolizes the idea of infinity and, at the same time, isolation of being; on the other hand, the choral appearance of the theme-cross means an orientation toward a lofty goal, towards a positive spiritual result.

Convincing examples of polystylistics are also found in the compositions of Boris Tishchenko. The author's language of B. Tishchenko does not hide its imitation by others and "confronts the listener with a characteristic paradox: on the one hand, almost any sound easily reveals its origin from alien material, and on the other hand, the 
authorship of the composer is just as easily established literally by several measures of music" $" 21$.

In musicological compositions about B. Tishchenko it is often said about the stylistic layering of his music, which is confirmed by his own statement: "The more composers I learned, the more I wanted to be like them. Obviously, I am driven by a love of other people's music, rather than a desire to counterbalance it with something "own"22. The main focus of B. Katz's work on B. Tishchenko's music was the theme of "own" and "alien". Many scholars of the composer's work are moving towards establishing the original sources of B. Tishchenko's music. They note the influence of folklore, Bach polyphony, and symphonism of L. Beethoven and D. Shostakovich on him. But the composer in his compositions addresses not only the past. The inclusion of B. Tishchenko's thinking in the sphere of modern music is noted by V. Syrov: "Perhaps there is not a single stylistic device from the huge encyclopedia of musical instruments of the XX century, which would be passed by his attention and tenacious memory" 23 .

It is the constant dialogue between "own" and "alien" in the music of B. Tishchenko that allows us to define his composer's method as a polystylistic one, associated with the disclosure of the "polyphonic" possibilities of each expressive device, each figurative element.

In terms of this dialogue, the work of V. Silvestrov is substantially aesthetically close to the work of B. Tishchenko. Both for one, and for the other, the starting points in music are genre and intonation, the second being, in the end, genre-conditioned, but in a much larger historical time - on a much larger, and, therefore, more responsible, semantic scale. Both B. Tishchenko and V. Silvestrov are not so much trying to attach music to themselves, to their personal composer's attempts, as they open up the possibility of becoming familiar with it, right up to the "departure" from creative egocentrism.

Valentin Silvestrov gave this new compositional position a very clear justification. In one of his interviews, he indicated that he never engaged in literal historical reconstruction of music or speculative experiments. $\mathrm{V}$. Silvestrov recognizes two main types of music: performing and

${ }^{21}$ Кац Б. О музыке Бориса Тищенко. Опыт критического исследования. Л.: Советский композитор, 1986. С. 138.

${ }^{22}$ Там же, С. 24.

23 Сыров В. Тищенко Б. Эскиз к портрету. Музыкальная жизнь. 1989. Вып. 5. С. 23. 
author's music, and identifies performing music with an anonymous and universal principle in music, and the second with an autonomous, personal composer. However, he argues that the anonymous, universal as a "common ground" should be present in any composer's opus. "A pure personality", writes V. Silvestrov, "constantly demonstrating itself, can turn into absurdity" $"$. In music, V. Silvestrov seeks to discover indestructible, that is, constantly present moments; according to him, "the world shines through musical-bodily forms - intonation, genre", 25.

In the music of V. Silvestrov, first of all, it attracts positive meaning, purity, a sense of life, spiritual kinship between people and eras. Therefore, the melodic possibilities of the formation and development of music remain of extraordinary importance to him. The composer himself admits that he is trying to build the form as a melody; in any case, for V. Silvestrov, the melodic-canted properties of the musical language and those European styles that are associated with the development of melodic thinking are important.

Valentin Silvestrov can hardly be called a neoclassicist, although he is in dialogue with the objective, that is, with the experience of musical creativity lying beyond his personal "I". He is extremely subjective, in his own way, as a rule, senses a distance in time and, denying it, uses the alien stylistic experience. However, according to V. Silvestrov, no style experience can be too alien. He writes: "No matter what language you speak, any composition is strongly not in direct meaning, but in allegory" ${ }^{26}$. Therefore, V. Silvestrov discovers the opportunity to use "obsolete phonemes", but pronounces them as his own.

Both B. Tishchenko and V. Silvestrov are united by the absence in their work of a method of caricature-like exclusion, of a grotesque in relation to borrowed material (so characteristic, for example, for D. Shostakovich). The mystery of their polystylistic method is that they do not so much to create a distance between "own" and "alien" as they try to come closer to it, they seek in this dialogue to find a new closeness, a new degree of identity.

The third tendency can be represented as the need of a modern author for new genre forms or for a radical update of the previous ones. So,

${ }^{24}$ Сильвестров В. Музыка - это пение мира о самом себе... Сокровенные разговоры и взгляды со стороны: Беседы, статьи, письма [автор статей, составитель, собеседница М. Нестьева]. Киев, 2004. С. 13.

${ }^{25}$ Там же, C. 13.
${ }^{26}$ Там же, С. 14. 
G. Ustvolskaya, for example, does not introduce catchy genre nominations (the exception is "Compositions"). However, a new stylistic interpretation of traditional genre forms (preludes, sonatas, symphonies) leads to their complete destruction - re-arrangement. This tendency is also characteristic of the work of B. Tishchenko, although to a lesser extent.

The genre installations of V. Silvestrov and A. Schnittke are innovative and are associated, inter alia, with the introduction of new genre forms. Especially interesting in this regard are the genre preferences of Odessa composer Y. Gomelskaya. The genre forms in her work are original and do not fit into any of the traditional canons. Many of her compositions for the chamber ensemble are striking in their variety not only in terms of instrumental compositions, which is one of the characteristic features of the poetry of a modern composer, but also in terms of the symptomatic nature of the names of a number of compositions.

Basically, these trends nevertheless rely on traditional genre prototypes (they do not completely deny them), but the composer's interpretation, as well as the dramatic conditionality as the dominant in their interpretation, allows us to put forward similar new nominative trends of genre forms:

1. A mnemonic genre trend, manifested in an appeal to the genres of memorial, postlude, postscript, "herbarium";

2. A meta-musical genre trend, starting from a composer's view of traditional means of expression from the perspective of a new sonorica (represents the area of greatest composer's freedom);

3. A monodialogical genre trend, based on reflection as a phenomenon that conveys the work of consciousness (more typical of compositions using serial technology $)^{27}$.

\section{Author's models of polystylistics in the works of modern composers}

An analysis of the work of a number of composers allows us to discover how the general trends presented above are refracted in individual composer's poetics, since polystylistics as a method of

27 Грибиненко Музыкальная полистилистика в свете теории интертекстуальности: дис. ... канд. искусствовед.: спец. 17.00.03 / ОНМА имени А.В. Неждановой. Одесса, 2006. 202 с. 
composing creativity presumes the author's figure as a leading, proactive one. Hence another internal contradiction of polystylistics: on the one hand, the rules for entering a musical text are limited; on the other hand, the individual-author refraction of these rules becomes different depending on the author's style and on the stylistic sources of the compositions of this author. Thus, it becomes possible to connect polystylistics with trends in the composer's style, to discover its individuality and author's autonomy. Compositional style trends determine the varieties of polystylistics; therefore its typology becomes open: new types of polystylistics appear with new authors.

In addition, it is found that the "reading" of one or another polystylistic device depends on the trends of the individual composer's style, on the personality of the author. Musical coding is also associated with this, that is, the creation using polystylistic techniques of a rather complex concept that goes beyond the boundaries of the musical and creative process. With coding (the choice of rules and their interpretation in the composer's composition), author's models of polystylistics are associated.

Thus, linking the above with the urgent problems of composer's creativity of the last decades, in particular, with the problem of polystylistics and discovering its new sides, we come to the following conclusion.

The nature, originality and basic functional aspects of musical polystylistics are revealed and can be considered at hierarchically different levels of modern composer poetics.

The first - a meta-level that goes beyond the limits of a separate composer's consciousness - characterizes polystylistics as an aesthetic phenomenon, the main principle of which is the disclosure of the existence of music as "an anonymous mainland, on which you should try not to leave traces" ${ }^{\prime 2}$. If the creative ideas of A. Schnittke, G. Ustvolskaya and Y. Gomelskaya belong to the tragedy aesthetic sphere, then the figurative content of the works of B. Tishchenko, V. Silvestrov forms the so-called "post-tragic" sphere.

The second level is connected with the understanding of polystylistics as a principle of composer's thinking based on dialogism, on the

${ }^{28}$ Сильвестров В. Музыка - это пение мира о самом себе... Сокровенные разговоры и взгляды со стороны: Беседы, статьи, письма [автор статей, составитель, собеседница М. Нестьева]. Киев, 2004. С. 17. 
interaction of the "architectonic" and "compositional" levels of a literary text (M. Bakhtin's terminology). Dialogue is an integral part of the thinking of all authors to whom the analytical material of the work is addressed.

The general laws of compositional forms are realized through the comparison and development of various types of expressiveness, types of psychological states associated with the embodiment of the main artistic meaning of the composition. The nature of the comparisons, the strength and degree of contrast, and the ways of its implementation form the basic principles of polystylistics as the leading composer's method that meets the author's conscious intention to introduce his design into the general style context of music.

The third level - compositional - is associated with the principles of polystylistics as a symbolic expression of the plurality of musical consciousness through the introduction by the composer of intertextual techniques (quotation, allusion, stylization, collage) into the text of a musical composition, which can function as a text code leading to an understanding of the author's concept, therefore, to understanding the musical text itself. This position allowed us to introduce three new nominations in the typology of polystylistics (monological, centripetal, centrifugal), which correspond to the author's models of this phenomenon in the works of Y. Gomelskaya, V. Silvestrov, B. Tishchenko, G. Ustvolskaya and A. Schnittke.

Thus, in unity with the typology proposed by V. Kholopova, the following varieties of polystylistics can be defined:

- Diffuse, characterized by a smooth transition from one style element to another, stylistic dispersion of the original thematic complex;

- Collage, based on contrasting, sometimes sharp ("shock") juxtaposition of style elements;

- Pluralistic, which is a fairly new, peculiar method of inconspicuous gradual stylistic modulation, which leads in general to the formation of a style that is not alien to any other;

- Centripetal, enhancing the internal tension of the image, focusing on the leading author's intonation, creating the similarity of various stylistic modifications, associated with dramatization and compression of the form (typical for the works of Y. Gomelskaya and A. Schnittke);

- Centrifugal, in which the new - as the author's own intonation, found by him through a complex interaction of genre and style «signs» of music - finds itself as an update of musical memory, that is, repetition 
and renewal of musical ideas without which it is impossible to imagine a value complex of musical culture. The intonational and stylistic novelty, the authorization of musical and dramatic concepts turn out to be a different linguistic form in comparison with the forms of expression of those main known meanings, which are always addressed by the artistic consciousness, which are a constant side in the evolution of the artistic method. Most of all, this type of polystylistics corresponds to the composer's poetics of B. Tishchenko and V. Silvestrov;

- Monological, for which individual musical expressive means, which the composer chooses for himself, are important; enrichment of the language occurs through the creation of new, previously unknown techniques, or the renewal of old ones, but so that the originality of the artistic discovery obscures the connection with tradition; «monological worldview» is a contrast to the traditional view of the world around the brightly individual vision. A striking example of this type is the work of G. Ustvolskaya ${ }^{29}$.

At the fourth level, polystylistics manifests itself as a stylistic idea, a bearer of stylistic semantics as a set of authorial compositional principles that have certain, fairly stable semantic functions. Each author creates his own model of polystylistics, draws his own conclusions, which is the most important factor in the formation of the deep idea of polystylistics and allows to reach the level of aesthetic generalization. From these positions, we can talk about the presence of a new epic in the work of B. Tishchenko, new lyrics in the work of V. Silvestrov (depersonalized, but meditatively profound). A. Schnittke and G. Ustvolskaya open up new possibilities in understanding the dramatic conflict and tragedy. In their work, they outline two completely different ways of developing this idea: old believer truthfulness leading to neoarchaics becomes an integrating principle in the poetics of G. Ustvolskaya; faustianism, postromantic skepticism is distinguished by the semantic system of music by A. Schnittke. Features of the author's style of Y. Gomelskaya can be defined as post-neoromantic.

Turning to the material of the study as a whole, we can distinguish two more inner-opposition pairs of tendencies in the development of the polystylistic method: tendencies of justification - unjustification as an

29 Грибиненко Музыкальная полистилистика в свете теории интертекстуальности: дис. ... канд. искусствовед.: спец. 17.00.03 / ОНМА имени А.В. Неждановой. Одесса, 2006. 202 с. 
artistic result of style compatibility (incompatibility) of textual material, which are sometimes directed towards paradox, grotesque, cartoon; intentional tendencies - unintentions associated with the occurrence of additional effects, some of which were not foreseen by the author and appear already in the context of listening perception.

\section{CONCLUSIONS}

Polystylistics as a composer's method expresses a certain dialogical position, for which the interaction of "own - alien" and "alien - own" is typical (however, typical of generating any text, which, in particular, is highlighted by M. Aranovsky in his study of structure and properties of musical text). Polystylistics goes through various phases of the dialogue: from submission to the authority of the "alien" - through the development of its logical apparatus - to self-legitimacy in relation to it, to the transformation of the "alien initiative" into the own. Various author's positions in relation to the textological material within the composition allow us to outline the main trends in polystylistics, namely:

- assimilation (consent, removal of the author's distance in relation to "alien" textual material);

- discrepancy (exclusion, partial distance in relation to "alien" textual material);

- identification (removal, rejection of the "alien", up to alienation);

- rejection (active rejection, deformation, breaking the borrowed stylistic model).

It is musicological analysis that allows us to identify the artistic significance of unintentional polystylistics as an important indicator of deep semantics (L. Hakobyan). This does not negate our definition of polystylistics as a conscious method of composer's poetics aimed at generalizing and integrating style material by creating a system of musical and stylistic references.

We conclude that polystylistics is a necessary category of musicology, which is declared directly by composer's poetics, that is, prompted by the experience of modern authors. As a musicology category, polystylistics opens up a wide range of cultural meanings, allowing it not only to enter the system of musical-cultural-scientific terms, but also to be determined by them in a certain respect. 


\section{SUMMARY}

The aim of our article is to identify the nature and levels of manifestation of the polystylistics phenomenon in the compositions of modern composers, which is the source of musical creative concepts in the semantic field of modern musical culture and provides a dialogue of styles, genres, forms, etc. It provides basic information about the interpretation of the term "polystylistics" in musicology, and also compares the methods and principles of polystylistics in connection with the main trends of modern composer's poetics.

The study proposes and substantiates the typology of musical polystylistics. In order to justify the typology of the phenomenon of polystylistics, the study pays special attention to the analysis of its author's models, based on chamber and instrumental compositions by Russian and Ukrainian composers. The identification of special types of polystylistics allowed us to introduce new nominations that reveal the essence of the creative method of the studied composers.

The mechanism of the implementation of the polystylistic method is considered on the example of music by G. Ustvolskaya, A. Schnittke, B. Tishchenko, as well as the compositions of modern Ukrainian composers - V. Silvestrov and Y. Gomelskaya.

\section{REFERENCES}

1. Арановский М. Музыкальный текст: структура и свойства. M., 1998. 343 c.

2. Бахтин М. Собрание сочинений в семи томах. Проблемы поэтики Достоевского. Том 6. М.: Русские словари, 2002. 505 с.

3. Грибиненко Музыкальная полистилистика в свете теории интертекстуальности: дис. ... канд. искусствовед.: спец. 17.00.03 / ОНМА имени А.В. Неждановой. Одесса, 2006. 202 с.

4. Грибиненко Ю. Парадоксы полистилистики в творчестве Г. Уствольской. Научный вестник НМАУ им. П.И. Чайковского. Музичний стиль: теорія, історія, сучасність. Киев, 2004. Вып. 38. C. 220-227.

5. Григорьева Г. Стилевые проблемы русской советской музыки второй половины XX века. М., Советский композитор, 1989. 208 с.

6. Кац Б. О музыке Бориса Тищенко. Опыт критического исследования. Л.: Советский композитор, 1986. 166 с.

7. Медушевский В. Стиль как семиотический объект. Советская музыка. 1979. № 3. С. 30-39. 
8. Назайкинский Е. Принцип единовременного контраста. Русская книга о Бахе. М.: Музыка, 1985. С. 265-294.

9. Назайкинский Е. Стилистика музыкального произведения. URL: www.harmony.musigi.dunya.az/harmony/rus

10.Савенко С. Есть ли индивидуальный стиль в музыке поставангарда? Советская музыка.1982, № 5. С. 117-122.

11.Сильвестров В. Музыка - это пение мира о самом себе... Сокровенные разговоры и взгляды со стороны: Беседы, статьи, письма [автор статей, составитель, собеседница М. Нестьева]. Киев, 2004. 265 c.

12.Сыров В. О стиле Бориса Тищенко. Проблемы музыки XX века. Горький, 1977. С. 21-27.

13. Сыров В. Тищенко Б. Эскиз к портрету. Музыкальная жизнь. 1989. Вып 5. С. 16-24.

14.Холопова В. Композитор Альфред Шнитке. Челябинск: «Аркаим», 2001. 255 с.

15.Холопова В. Музыка как вид искусства. М.: Научнотворческий центр «Консерватория», 1990. 260 с.

16. Холопова В., Чигарева Е. Альфред Шнитке: Очерк жизни и творчества. М.: Советский композитор, 1990. 350 с.

17.Энциклопедический музыкальный словарь. М., Советская энциклопедия, 1990. 672 с.

\section{Information about the author: Grybynenko Ju. O.,}

Ph.D. in the History of Art, Assistant Professor at the Department of Music History and Musical Ethnography, Odessa National A. V. Nezhdanova Academy of Music 63, Novoselsky str., Odessa, 65023, Ukraine 


\section{INSTRUMENTS-IMAGES IN MUSICAL SCIENCE AND PRACTICE}

\section{Chernoivanenko A. D.}

\section{INTRODUCTION}

Since the second half of the XX century, the semiological potentials of science (and the development of semiotics as a special science), which are gaining strength, began to actively penetrate into musical aesthetics and musicology. This process was facilitated in many respects by musical avant-garde movements, the figurative and technological parameters of which stimulated debates about the ability of music to express specific meanings using concrete (primarily instrumental) means. A certain confrontation unfolded between the supporters of music interpretation as an asemantic reality and as a system of signs. And although, on the whole, more supporters found a statement about music as a means of specific artistic communication, the mechanisms and nature of musical significance, symbolism, sign remain today promising objects of scientific research. The point here is not only the need for a certain sign system in a "pure" musical and instrumental "message", communication, where there is no verbal text that largely determines or contributes to the formation of a holistic meaning, as well as purely musical intonations in terms of instrumental accompaniment to singing. In purely instrumental creativity, the mechanisms of associative-sound memory are activated, preserving certain semiotic signs of the instrument itself in its materialized organological (timbre, type of instrument, methods and techniques of the play), as well as situational and substantive (ritual, leisure, work processes, etc.) and genre and style expressions.

With time out of mind, from birth to death, in various layers of life from work and leisure to spiritual and aesthetic, a person has been accompanied by music, song, and dance. Musical instruments are an integral part of all these events, rituals and reflections: from primitive to the most complex and most sophisticated in acoustic and even engineering terms, from hand-made from "improvised means" to masterful works of art, such as, for example, the Guarneri and Stradivarius violins, which in the hands of the master and performer are capable to express the finest facets of complex mental and sensory 
processes. It is clear that a musical instrument is unique (and for a performer it is often spiritually personified, miraculously mythological), a co-creator in broadcasting musical ideas, and not an independent, self-sufficient expresser of them. However, in a complex system ("semiosphere") of instrumental creativity, this instrument in the process of performing an act is spiritualized in a certain way and possesses characteristics not only of a carrier (sound, situational and symbolic, substantial and style) image, but also an initiator of linguistic and figurative structures capable of directing the development of musical thought of its creator - man.

Various types and modifications of musical instruments, constants and changes in their symbolic meaning fully reflect the movement of the cultural and historical process as a whole, the evolution of the picture of the world and the collision of man and the universe in its wholeness. The symbolism of musical instruments has played an important role for thousands of years in life, thinking and various types of creativity in connection with the place that music occupies in the spiritual life and culture of mankind. Therefore, elucidation of the basic principles of such symbolism is an actual scientific direction in musicology (and wider) research. And it is here that structural semiotic approach, developed by Y. M. Lotman, is effective as one of the important ways to comprehend complex objects, such as an art work, the cultural era, musical and instrumental culture and musical instruments themselves. The structural method, according to Y. Lotman, ensures the logic of the study, the validity of the conclusions and the ability to show the integrity of the object.

\section{A musical instrument in the light of the structural and semiotic concept}

The study of musical and instrumental culture, from its ancient and folklore samples to works of high professional composer music of recent eras and modern times, is in the field of scientific principles for the study of culture as a whole and the mechanisms that generate it, formulated by Y. Lotman. This refers to its understanding of two-dimensional and twohemisphere consciousness according to the scheme of structural binary oppositions (logical - mythological, discrete - continuous, material ideational). According to the theory of Lotman's structural and semiotic concept, art works of past (including very distant) eras of culture «continue to actively participate in its development as living factors». In culture, not only the immediate chronological period "works", but "the 
entire thickness of the culture texts, everything that is contained in its memory, is directly or indirectly included in its synchrony" 1 .

In this regard, a musical instrument, even if it has undergone significant modernization, retains the entire "plume" of its historical properties - functionally situational, genre, style, and semantic qualities, somehow introducing them into new linguistic and style data. The instrument as a "living factor" for the further development of its own "semiosphere" translates accumulated signs-symbols, and the composer and performer superimpose on them new formed ones, in accordance with the epoch-style, individual-style settings, and general heuristic positions of creativity.

Thus, within each musical and instrumental culture (as well as in musical instrumentalism as a whole), semiotic diversity is constantly increasing, while maintaining the key stable, centuries-old symbolic characteristics of instrumental materiality - the timbre, the ways of «communication» of the performer with the instrument, that is the methods of sound production and sound science, etc. (for example, the emotional sensuality of the bow, relative neutrality of the pinch, significant neutrality of the piano).

Each of these, having the value of the sign organization nodes, is able to show a tendency to become a kind of "cultural personality" (Y. Lotman) - a "closed immanent world with its own internal structural and semiotic organization, its own memory, individual behavior, intellectual abilities and self-development mechanism» ${ }^{2}$. As a result, the musical and instrumental culture as a whole, as a system, as a whole organism, is a combination of such "quasi-personal" semiotic formations and the communication system between them in the system "composer instrument - performer - listener» in different positions, between instrumental and vocal creativity, between various types of arts, in culture, within and between eras, national conditions, etc.

One of the principles of the structure organization is binary relations. But the result of the system description is often rigid structural poles, and a wide strip of neutral elements having a dual relationship to them is simply not captured. This removes the internal incomplete ordering of

1 Зайнетдинова Р.А. Становление проблемного поля концепции семиосферы Ю.М. Лотмана: историко-философский анализ: автореф. дисс. ... канд. филос. наук: 09.00.03. Екатеринбург, 2011. С. 21.

2 Зайнетдинова Р.А. Становление проблемного поля концепции семиосферы Ю.М. Лотмана: историко-философский анализ: автореф. дисс. ... канд. филос. наук: 09.00.03. Екатеринбург, 2011. С. 21. 
the system, which gives it flexibility and increases the degree of behavior unpredictability. Ambivalence (duality, ambiguity) as a certain cultural and semiotic phenomenon was first described in the works of M. M. Bakhtin. The growth of internal ambivalence corresponds to the moment the system transitions to a dynamic state. Also, one of the mechanisms of semiotic evolution is the swing between the dynamic state of indescribability and the statics of self-descriptions.

In music, there is a type of signs, the so-called «symbols of receptive expectation, thanks to which the listener prepares himself in advance for what is to be heard» ${ }^{3}$. The action of such symbols extends not only to the spheres of musical intonation (in the broad sense), image, thematism, harmony, but also to the image of the instruments themselves. For example, brass instruments are expected to be embodied in heroics, fanfare invocations, hunting or military personifications and generalizations, and from the end of the XX century - jazz-pop manifestations. Bowed stringed instruments - maximum imitation of the human voice or concert-virtuoso imagery. The organ - sublime spiritual incarnations.

The accordion or bayan - rather popular-democratic, pop or folk music. A neutral in timbre piano - sonata-symphonic concepts, chamberrefined images (associated with professional composing), jazz rhythms, etc.

In this sense, the concept "sound image of an instrument", derived already in the XX century, is important. L. Gakkel introduced the concept of a "sound image of an instrument" into musicology in the book "Piano Music of the XX Century", obviously, based on the term of A. Copland "sonorous image" from his work "Music and imagination". Copland establishes a close relationship between the evolution of the instrument, as a constructiveacoustic phenomenon, and composer creativity. Gakkel, using the term a sound image relative to a specific instrument - the piano, gives the original concept of Copland a slightly different semantic meaning, referring to the "sound material of music" and the impression, the impact of music on the

3 Лазутина Т.В. Процесс символизации в музыке: дис. ... канд. филос наук: 09.00.01. Тюмень, 2003. С. 123.

${ }^{4}$ Гаккель Л. Фортепианная музыка ХХ века: Очерки. 2-е изд., доп. Л.: Сов. композитор, 1990. 288 с.

5 Copland A. Music and imagination. Cambridge: Harvard University Press, 1952. Second printing. 
listener". A. Malinkovskaya introduces the concept of "sound complex" (sound image) of a piano, which is closely interconnected with a wide range of means of piano expressiveness ${ }^{7}$. The scientific apparatus of the dissertation work by T. Budanova is based on Gakkel's terminology. The "sound image of an instrument" is considered in the triad "organics (instrument construction) - intonational meaning, realized through a complex of means of artistic expression - the listener's perception" Through comprehension of this triad, the author comes to the definition of the sound image in two aspects - wide and narrow. The first is "the sound material of music, reproducing in intonation practice the whole variety of manifestations of functional polyvalence. The second is the concrete facet of this multivalence ("bayan image", "harpsichord image", "piano", "jazz", "impressionistic", "romantic", "constructivist", "elitist", etc.). S. Ivanova proposes the concept of "sound image of an instrument", three interrelated and interdependent factors becoming essential for its evolution: performing traditions, the composer's musical text and the results of improving instrument designs in order to identify new expressive techniques and expand technical capabilities ${ }^{9}$. We would add here the cultural and historical context of the instrument appearance and evolution, the symbolic field that was formed with its participation in the spiritual, ritual, leisure and everyday, literary and poetic, pictorial and philosophical contexts. A. Timoshenko's dissertation work is connected with these problems, exploring the notions of sound, the concept of the instrument and composition of American composers. It introduces the notion "artistic and acoustic type of instrument" related to the mentioned above, which means "the musical and acoustic qualities of the instrument accepted by one tradition or another and developed executive techniques of playing it, as well as an idea of the boundaries of this instrument capabilities"10.

6 Гаккель Л. Фортепианная музыка XX века: Очерки. 2-е изд., доп. Л.: Сов. композитор, 1990. С. 6

7 Малинковская А.В. Класс основного музыкального инструмента. Искусство фортепианного интонирования. М.: Владивосток, 2002. 381 с., нот.

${ }^{8}$ Буданова Т. Музыка для баяна композиторов Сибири и Дальнего Востока: автореф. дисс... канд. искусств.: 17.00.02. Владивосток, 2009. С. 27.

9 Иванова С. Эволюция звукового образа балалайки: автореф. дисс... канд. искусств.: 17.00.02. Магнитогорск, 2009. С. 9.

10 Тимошенко А. Американский музыкальный экспериментализм первой половины XX века: представление о звуке, концепция инструмента, композиции (Г. Коуэлл, Дж. Кейдж, Л. Хэррисон): дисс. ... канд. искусств.: 17.00.02. СПб., 2004. С. 16. 
Among the phrases aimed at determining the essence of the instrument interpretation, we also meet the concept of "image of the instrument" (in an acoustic, not in a poetic, mythological or pictorial sense) without a qualifying adjective "sounding" or "sound"11. According to the author, the characteristics of the instrumental style «in relation to the signs of the composer's style ... create the image of a musical instrument». The author notes that the formation of instrumentalism is significantly influenced by the structure of the instrument and the "specificity of intonation being". The signs of the composer's style are manifested in the fact that the artist selects and adapts the technical, acoustic and expressive capabilities of the instrument to his own plan, for example, methods of sound production, manner of performance, genre semantics, as well as "intonation dictionary" (B. Asafev).

N. Ryabukha analyzes the concept of a "sound image" as a cultural concept, as a historical and cultural image of the era, which reflects the sound and musical consciousness of society: "A sound image as an established (but not yet sufficiently studied) category of musical creativity and thinking is an informational art "code" of a work in which the image of a person and his historical time in the space of sound being is contained in a convoluted form» ${ }^{12}$.

It should be emphasized that in all forms of musical creativity there is always a figurative beginning, since any art form involves a figurative reincarnation of objective reality. However, the instrument itself, accumulating the experience of organological improvement, the performing skills of playing it and the composer's repertoire with the corresponding ideological and figurative genre and style baggage, is able to act as an image, more precisely as a sign-image, which is characterized by the binary nature of instrumental, material and ideational (spiritual and philosophical, cultural, historical, social) parameters in their organological, performing, composer aspects. Their combination, interconnections and mutual influences give grounds for creating a kind of "cultural personality" - an instrument of the era, nation, style, genre, individual quality with specific and universal characteristics.

11 Башарова И. Образ флейты в сонатине Губайдуллиной. Вестник Башкирского Университета. Уфа, 2008. №3. С. 595-598.

12 Рябуха Н. Звуковий образ як феномен культури: досвід міждисциплінарного синтезу. Культура і сучасність. К., 2014. Вип. 2. С. 116. 
Complex iconic formations in music direct the attention of the listener, composer and performer to the subject of attention. The dominant sign (symbol) causes a certain reaction, which is correlated with other sign (symbolic) couplings that correct the "boundaries of the general expectation" based on the immediate task ${ }^{13}$.

\section{Musical instruments-images in literary and poetic creativity}

Musical images, and above all, musical instruments, due to their symbolism accumulated over centuries, receive various forms of aesthetic embodiment in culture, in various types of art. Here they become images of the music itself, capable of (with or without words, in pure instrumental quality) embodying ideas that are a little accessible or inaccessible to translation into a verbal language (due to the specificity of the musical language ${ }^{14}$ ). According to L. Herver, the images of musical instruments largely determine the ideological and figurative field in mythology and literature ${ }^{15}$. It was in mythology that the foundations of the symbolic "reading" of various instruments in philosophy, painting, literature, music itself and human life were formed. Herver argues that the images of musical instruments are an important link of all time «just like real instruments, which have preserved the principles of sound production and a number of names since the beginning of time» ${ }^{16}$. That means, the instrument acts as a mediator, a special form of communication and the existence of mankind in the cultural and temporal vertical in a semiological context.

The brightest examples of such musical and instrumental imagery are presented not only in the mythological symbolism of all peoples, without exception, where the musical instrument enters into a relationship of transformation and identity with all elements of the mythological world and with this world itself; an important role is played here by the origin and belonging of musical instruments, often received as gifts from gods or cultural heroes, or made by them. Already in ancient mythology various types of musical instruments are reflected with the corresponding

${ }^{13}$ Семиотика: Антология / сост. Ю.С. Степанов. Изд. 2-е, испр. и доп. М.: Академический проспект; Екатеринбург: Деловая книга, 2001. С. 73.

14 Chernoivanenko A. Musical and instrumental foundations of modern composition techniques. National academy of managerial staff of culture and arts Herald. 2'2019. S. 444-448.

15 Гервер Л. Музыка и музыкальная мифология в творчестве русских поэтов (первые десятилетия XX века). М.: Индрик, 2001. С. 67.

16 Там же. 
division of spheres of influence, which is «marked by stringed - wind percussion instruments (sometimes stringed - wind + percussion), which are owned by: men and women, celestials and people, etc." ${ }^{17}$ A. Losev points out that among the Greeks not all instruments were considered suitable for musical education (for example, the flute was excluded).

In the «Revelation of St. John the Evangelist,» concluding the Bible, the birth of a new world begins after the Last Judgment and the end of the world. When depicting the Apocalypse, the symbolic meaning is embodied in the images of trumpets: "And I saw seven Angels who stood before God; and they were given seven trumpets» ${ }^{18}$. The trumpet has long been used for delivering certain signals on the hunt, in the military affairs. In this regard, it is logical that the alternate sounding of seven trumpets in the Apocalypse means the beginning of the end of the world. Interesting is the fact that in S. Esenin's "Sorokoust", the death of the world (the village) announces the "death horn", and not the trumpet of the apocalypse angel, but from the shepherd's horn, predicting the death of the village world"19. In the musical work itself, the horn is also a symbol and image: the golden passage of the horn (Haydn, Mendelssohn, Tchaikovsky), the horn of Oberon in Weber's opera, etc.

In the Christian picture of the world of the Middle Ages, there was a divine and harmonious music of the heavenly spheres and the infernal music of the Sabbath of witches. Fantastic musical instruments with figures of people crucified on them appear in the paintings of I. Bosch. Angels are depicted with harps or flutes. For a romantic person, the metaphor of a "broken heart" often appeared in associative connection with torn strings and a broken musical instrument. "Evolution, moving in the direction of more and more "animation" and personification of the instrument, and, first of all, the replacement of wind instruments with stringed ones, reaches its goal here - in the work of romantics, it becomes a double of the hero, his second «II», sensitively reacting to all the throwing and suffering of the romantic soul"20. It is necessary to note that in European culture, starting from the Renaissance, the violin is a symbol of the female voice, soul.

${ }^{17}$ Гервер Л. Музыка и музыкальная мифология в творчестве русских поэтов (первые десятилетия XX века). М.: Индрик, 2001. С. 67.

${ }^{18}$ Откровение. 8:2. Новый завет.

19 Воронова О.Е. Сергей Есенин и русская духовная культура. Рязань: Узорочье, 2002. С. 396.

20 Карабегова Е. Символика музыкальных инструментов в немецкой литературе XIX - XX веков и «Контрабас» Патрика Зюскинда. 
The variety of musical instruments, the «world orchestra» should also be understood as a symbol of the spiritual order. Rightly pointing out that "musical instruments alone cannot reproduce praise" ${ }^{21}$, P. Masters notes the ability of the sound characteristics of various instruments to describe «various feelings inherent in true worship».

A whole system of musical and instrumental imagery was built by symbolist poets and acmeists in the XX century. It is interesting that V. Khlebnikov in his essay "Our Foundation" proves (based on the methods of physics) a new temporary law that he "discovered": the repeatability of historical phenomena allows us to divide the history of mankind into periods and thus predict the future. According to his theory, the poet sought to recreate the original unity, overcoming the fragmentation of time, which disperses all that exists. For new people who are immortal and who have mastered the secrets of time, that is, "aveniristes", carriers of "higher intelligence", according to Khlebnikov, a new adequate system is needed. There semantically significant sounds play the main role, each of which "hides a certain image and is a name» and voices the physical laws of body motion. ${ }^{22}$ In such sound semantics, the leading role is played by image instruments. For Khlebnikov, these are images of the "trumpet of the world", "strings" (here the strings and winds are universalized, losing the acuteness of the ancient Greek confrontation), "harp of time", "balalaika of time" (national component), and the lyrical hero feels himself simultaneously in the present, in the past and eternity. The indicated by Khlebnikov original images of musical instruments are beyond the action of life and death, their destiny is eternity. Thus, image instruments illustrate the structure of the semantic field of Khlebnikov's utopian theory of time and the desire to grasp the internal energy, the conventions of life and poetic language ${ }^{23}$.

Very often it is the images of musical instruments in literature and poetry that function to convey the emotional state of the lyrical hero (for example, a bell, piano, violin - by O. Mandelstam; guitar, violin, harmonica - by S. Yesenin; harp, violin, bell, orchestra - by Annensky, etc.). It is noteworthy that Mandelstam's universal lyrical hero (European, heir to the values of the entire "Judeo-Christian-Hellenic culture" rather than the culture of his country ${ }^{24}$ ) "chooses" mainly

${ }^{21}$ Мастерс П. Богослужение: библейское и современное.

22 Давыдова А.В. Музыкальные образы в русской лирике начала ХХ века: автореф. дисс. ... канд. филол. наук. Архангельск, 2006. С. 12.

23 Давыдова, 2006. С. 16.

24 Давыдова, 2006. С. 17. 
academic instruments, gravitating in their status to universalism, the European center, demonstrating the synchronism of existence of temporary, genre, national principles, sealed with a «moral personal memory" 25 . S. Yesenin, by contrast, through a musical instrument transmits the national principle (harmonica, guitar).

Considering the mythology associated with musical instruments, L. Herver states: "The more musical a work of literature is, the more mythological it is. And in order to understand how his musical form works, sometimes it is necessary first of all to carry out a mythological analysis" 26 . In Yesenin's "Sorokoust", for example, literary scholars find the leading principle of musical drama (according to B. Asafiev) juxtaposition and interaction of contrasting imaginative spheres: biblical mythology embodied in the image of the "perishing horns" and the myth of the last village poet associated with the image of "crying" harmonica. The antithesis of the sound of two musical instruments is: the "death horn" and the "voiced talianka" correlates with the tragic confrontation of these images, which confirms the validity of the statement by A. Davydova: "The musical images reflected the catastrophic consciousness of a person on the verge of the XIX - XX centuries related to the feeling of inevitable fatal changes" ${ }^{27}$. This musical form is transmitted through the images of musical instruments; it becomes a characteristic feature of twentieth-century poetry.

However, the binary nature of the figurative spheres can be embodied in the monotheme of musical instruments. So, the image of the guitar appears with many sides, transforms in its personification throughout the entire career of Yesenin (it is either a tavern, a "cursed", or a noble compared to a harmonica). An anthropologically personified image of the string as a naked nerve of a musical instrument and a lyrical hero is interesting. Therefore, this image often has a confessional character; it is associated with the desire of the lyrical hero to express the most secret.

Thus, musical images (primarily instruments), being the embodiment of the idea of artistic synthesis and realizing the principles of musicality, occupy an important place in the poetry of the XX century. Images of musical instruments are used mainly to characterize the lyrical hero; a figurative description of the elements of the external world, the sound

25 Давыдова, 2006. С. 16.

${ }^{26}$ Гервер Л. Музыка и музыкальная мифология в творчестве русских поэтов (первые десятилетия XX века). М.: Индрик, 2001. С. 163.

27 Давыдова А.В. Музыкальные образы в русской лирике начала XX века: автореф. дисс. ... канд. филол. наук: 10.01.01. Архангельск, 2006. С. 14. 
characteristics of a particular phenomenon - by likening one element to another according to the similarity of certain signs. This helps to achieve a special artistic effect. Even if musical images are not central, fundamental to a poetic picture of the world, they perform a number of functions, namely, they combine a number of artistic images of music, through the implementation of which the poet learns the world. Musical images also reflect the psychological state of the lyrical hero, transmit intimate experiences. And even the absence of any musicality can be interpreted as bad times coming. Since the lyrical, personal principle plays an important role in poetry, musical imagery helps to realize this semantic field.

Each instrument, as a sound symbol of the era, of national culture, in which it particularly clearly showed its capabilities in reflecting cultural and musical paradigms or even contributed to the creation of these paradigms, has historical preconditions for interpreting sonority, which determine its ability to reflect the concept of intonated attitude.

\section{Image of the instrument in performing and composer's work of the XX - XXI centuries (on the example of partita by S. Gubaidullina «Seven Words»)}

Since ancient times, musical instruments were endowed not only with personalized, anthropological features, but also acquired special symbolism, semantic qualities assigned to this type of instrumentation. Therefore, musical and instrumental art was deeply revered already in antiquity. So, in the Sumerian-Babylonian kingdom, sacrifices were performed in honor of musical instruments. According to the ideas of the Sumerians, the gods were not only music lovers, but also musicians. And in the state hierarchy of Sumer, the musicians stood directly behind the gods and kings. Historical sources allow us to talk about a rich, diverse and relatively perfect musical instrumentation by the beginning of the III millennium BC. Along with images of musical instruments, scientists also found the remains of the instruments themselves: a variety of percussion instruments (mainly drums and sistrums); among the winds an archaic longitudinal flute, close to the ancient Egyptian, reed - like the oboe; among strings there are (as in Ancient Egypt) harp-shaped lyres, harps, lutes. In the ensembles of Sumer-Babylonia, percussion instruments are combined with strings and winds. The kalu-priests (singers) accompanied their "performances" with playing musical instruments (the applicant for the title of priest should have possessed this, together with other skills). The ritual of the Kalu mass is described in Uruk texts with the smallest details. Methods of playing musical 
instruments are also indicated, in particular those relating to lilissu (obviously corresponding to the tympanum). It even describes a method of making it, painted with sacredness: it all starts with the sacrifice of a bull that must give its skin for lilissu. In general, the musical instruments of the Sumerians were of particular cult significance. So, for example, harp, trumpet, drum were also used as a means of scaring away evil spirits. They received magical power as a result of the priest's manipulations. Rituals were performed with singing hymns and prayers of thanks accompanied by a harp, flute and drum. The trumpet and drum depicted the «voice» of the deity. In the ancient cult of the dead, a funeral procession went to the burial place with the music of trumpets, drums and the choir of church singers. In Sumer-Akkadian mythology, Gilgamesh made a sacred drum.

The ancient Greek opposition of strings and winds symbolized the Apollonian and Dionysian principles, which received a philosophical interpretation from Nietzsche. They manifest two poles of a diverse human culture. For Nietzsche, Apollo is the embodiment of the spirit of Hellas, the Greek classics, a bright, rational beginning, in contrast to the Dionysian currents - dark, ecstatic, passionate, chaotic, orgiastic and irrational. Nietzsche saw the ideal in the balance of the Apollonian and Dionysian. Their synthesis consists in struggle and unity. The highest synthesis of plastic art of images and non-plastic art of music is enclosed in ancient tragedy. From Losev's point of view, Nietzsche's both beginnings bear the stamp of a new European outlook, characteristic of "romanticism" with its endless aspiration and formation of an idea ${ }^{28}$.

It is interesting that the symbolism of musical instruments is used in the musical concepts themselves, in musical works. So, in S. Gubaidullina's partita "The Seven Words of Christ" for the bayan, cello and chamber orchestra, pierced by symbolism by virtue of the concept itself, the bayan stands on behalf of God the father, the cello - God the son, and Music itself - the Holy Spirit.

The idea of the work is connected with the high spiritual secret of mankind in the events of biblical history: the cross sufferings of the Son of God, His resurrection and the salvation of the world from eternal darkness through these innocent sufferings. This sacred theme has been repeatedly raised in works, including musical art, by composers of various eras, style and worldviews, embodied in various musical,

28 Лосев А. История античной эстетики: Аристотель и поздняя классика. М.: Искусство, 1975. 
linguistic, style, timbre and instrumental means (for example, G. Schutz and J. Haydn). S. Gubaidullina's appeal in 1982 to such a complex theological concept reflects the trends of music of the second half of the XX century in the direction of "new spirituality".

The work of S. Gubaidullina, performed with avaricious intonational and musical means, reaches an unheard depth of spiritual experience, conceptuality. The laconicism of spiritual revelations is known; a clear system of their symbols, not always understood by our contemporaries; the parable of the language of Christ. So, during his cross suffering, Jesus said only seven phrases that formed the basis of the composition by S. Gubaidullina.

Two instrumental and textural finds-symbols representing the specifics of these particular instruments - their characteristic materiality, penetrate the entire musical fabric and broadcast the main idea of the work. This is a spatially tangible and succinctly inscribed short textured formula, a sacredly significant symbol of the Cross. The cello has the intersection of two adjacent (per second) and oppositely glissando sounds. The bayan has a non-tempered glissando where a vertical (a metal tongue detonating with the help of fur and carcasses detonating) and a horizontal (superimposed on the original voice pitch) are superimposed. This symbol of the Cross is played by parts and bayan, and solo cello, each separately. Moreover, this is a rather difficult to execute instrumentally thematic moment and it embodies the specifics of texture and sound extraction of instruments. In addition, the bayan embodies the symbolism of the organ church culture, and the cello earthly suffering, expressed by its «human» voice.

Another significant textured sign is a piece with accelerationdeceleration and, accordingly, crescendo-diminuendo with a bow (cello) and fur (bayan), embodying wave-like processes of tension and the symbol of the Cross: the vertical of expanded space and the horizontal of high-altitude intonation and spatial "folding" to the original sound supply status. Cross-shaped symbolism is also formed during the combination the symmetrical application of the timbres of the bayan and cello in a détaché with fur or bow.

The author's choice of instruments - the bayan and cello - from the point of view of spatial (musical and real) perception of sound production in the arrangement of instruments makes up a mystical conditionality with cross-shaped symbolism. The vertical intonationaltitude indicator of the keyboard keys and strings on the neck "intersects" with a specific means of sound extraction: horizontal movement of the bayan fur and cello bow. 
The first part is a word - "Father! Forgive them, they don't know what they are doing" - minimalistically built on tone $\boldsymbol{a}$ (symbol of light) and consists of the presentation of all three described cross-shaped symbols in the bayan and cello. The dramatic intersection of the two instruments unfolds into a powerful symmetrical moderation-crescendo and foldingdiminuendo. After a general pause - enlightened prayer «singing» of both instruments on $\mathrm{pp}$ - as the forgiveness of a sinless God.

The intonation center of the second part ("Wife! This is your son ... this is your mother!") - altitude $\boldsymbol{d}$. The cross-shaped symbols of the Cross, already familiar to us, alternate with "humanized" legato-voiced structures: the intonations of "crying" indicate the vocal nature of these melodic statements. Clusters of the bayan - the uneven gait of the Way of the Cross or the beats of the weak heart of the Crucified - are as empathy of the Father.

The third part ("Truly I tell you, now you will be with me in paradise") increases the tension of the Event. In the musical fabric, a cluster layer is activated; this naturally makes up mainly a bayan party. Octave fanfare is a harbinger of what will happen.

The fourth part ("My God, my God! What did you leave me for?") is large-scale in size, texture and dramatic tension. This is the moment of the highest suffering and human weakness of the God-man - an instant artistically "enlarged" into a large-scale composition. The melodic structures in the right and left keyboards of the bayan do not metrically coincide with each other, with the cello and the orchestra, demonstrating emotional imbalance.

The fifth part is "Drink". Against the background of small pizzicato cello utterances around the center $f$, the bayan player continuously performs the non-tempered glissando, which is usually used not so often in a row: a complicated performing technique as the lasting suffering of a thirsty.

In the Sixth part ("It happened"), Gubaidullina uses a graphical record of various sonor-aleatory "explosions": clusters of various intensity, sound-quality filling, duration, range, dynamics, as well as naturalistic "sigh-sobbing" of the bayan air intake (device buttons for silent compress-drop of fur). Perhaps these recordings of sonor effects were made for the first time in the bayan literature. All this makes up, on the background of the orchestral second "glide", the embodiment of the unearthly nature of musical expression: the Mysterious happened.

The final Seventh part - "Father! In Your hands I give my spirit" represents a sound reflection of the Mystery that is immense for the human mind, which is set forth by "otherworldly" ("non-own") timbre- 
invisible instruments. The cello has harp flagships against the background of extended durations behind the stand. The bayan has heterophonic polyphony in both keyboards around the tone $\boldsymbol{a}$ of the second octave: long trills against the background of a sustained note in the left keyboard, which do not coincide in meter with the two-voice of the right keyboard - syncopations and small chromatic "whirling» (a kind of complex intersection).

A cross-shaped texture is formed twice in the orchestra. However, everything disappears...

Thus, the musical idea of the work is composed of symbols of various levels: textured, high-altitude, metro-rhythmic means; personification of solo instruments taking into account their individual instrumental specifics. Dramatic dynamics is achieved by textural and timbre tension and visually perceived instrumental effects. These instruments take on not only thematic, but also compositionally-forming, structural functions, as well as the expressed functions of the symbol and image. It is also important that the artistically-philosophical aspect of the performing process in the presentation of such symbolism, the ability of the performer to create a special spiritual and creative "pre-tuning" in the performance. It is not without reason that the work is dedicated to experienced, "verified" like-minded composers - cellist V. Toncha and bayan player F. Lips.

The sound image and symbolism of the bayan and cello are presented as clearly as possible in sound and visual aspects. This is especially true for the image of the Cross, which is literally «drawn» on the instruments and in the performing movements of musicians. It creates the impression of a church space where the actions and prayer of the priest and parishioners are combined into a single whole with architectural and pictorial means and sounding music. Their «difficult amount» greatly enhances the impact. The personification of the bayan and cello gives the instruments a figurative characteristic, recognizable by individual and, at the same time, generalized features.

\section{CONCLUSIONS}

Thus, the symbolism of musical instrumentalism, reflecting the key positions of the philosophical image of the world and the materiality of the instrument itself, embodies the important semantic postulates of a person's spiritual and mental life in the dynamics of their development. It is a symbol of the universe harmony.

Musical and instrumental symbols (and semantics), forming over the course of a thousand-year history of culture and appearing as a sign of 
music itself (which is most actively used in related forms of art, primarily literature, poetry, painting), contributed to the birth of signs-images of individual instruments both in musical art, and in related forms of creativity. Translation of functional and situational, genre, style, and semantic parameters of such signs-images is inevitable even when playing on modernized instruments and in interpreting the latest style and language means of music. Preservation of symbolic memory accumulated over centuries contributes to the integrity of a specific instrumental culture, while being open to both individual style (composer and performing), as well as epoch-making innovations, general heuristic settings.

In the context of the stated problems, the concept of "sound image of an instrument" is gaining importance. For its evolution, several interdependent factors become significant: performing traditions, composer language (text), organological parameters of the instrument (all three contribute to the identification of new expressive techniques of the play), as well as the cultural and historical, semantic and symbolic fields that developed during the participation of this instrument in the spiritual, ritual, leisure and domestic, literary and poetic, pictorial and philosophical contexts.

In general, given the presence of the figurative beginning, as the figurative reincarnation of objective reality, in all forms of musical creativity, the musical instrument itself, with the accumulation of the qualities of organological and performing technologies, the composer's repertoire with the corresponding ideological and figurative, genre and style baggage, becomes a sign-image that is characterized by the binary nature of instrumental material and ideational (spiritual and philosophical, cultural and historical, social) parameters. Their combination, interconnections and mutual influences give grounds for creating a kind of "cultural personality" - an instrument of the era, nation, style, genre, individual quality with specific and universal characteristics.

In the semantic field "music" the image of a musical instrument (next to the images of a song, actually music, etc.) acts as one of the main semantic centers. In this process, one can state certain evolutionary positions in the direction of enhancing the personification and individualization of instruments, replacing wind instruments with strings, the formation of complex keyboards, crystallizing achievements of chamber ensemble and orchestral capabilities, the development of one's own language and communication methods. These vectors achieve their goal in the work of romantics, where the instrument becomes not just a 
mirror, but a double of the hero, his second «I $»$, sensitively reacting to all mental expressions.

The XX and XXI centuries continue the development of these processes of constructing image instruments, demonstrating the strengthening of instrumental materiality, which is proved by the example of partita by S. Gubaidullina for the bayan, cello and the chamber orchestra "Seven Words".

\section{SUMMARY}

The mechanisms and nature of musical significance, symbolism, sign remain promising objects of scientific research nowadays. The point here is not only the need for a certain sign system in a "pure" musical and instrumental "message", communication, where there is no verbal text that largely determines or contributes to the formation of a holistic meaning, as well as purely musical intonations in terms of instrumental accompaniment to singing. In purely instrumental creativity, the mechanisms of associative-sound memory are activated, preserving certain semiotic signs of the instrument itself in its materialized organological (timbre, type of instrument, methods and techniques of the play), as well as situational and substantive (ritual, leisure, work processes, etc.) and genre and style expressions.

Musical and instrumental symbols (and semantics), forming over the course of a thousand-year history of culture and appearing as a sign of music itself (which is most actively used in related forms of art, primarily literature, poetry, painting), contributed to the birth of signs-images of individual instruments both in musical art, and in related forms of creativity.

In the semantic field "music" the image of a musical instrument (next to the images of a song, actually music, etc.) acts as one of the main semantic centers. In this process, one can state certain evolutionary positions in the direction of enhancing the personification and individualization of instruments. The XX and XXI centuries continue the development of these processes of constructing image instruments, demonstrating the strengthening of instrumental materiality, which is proved by the example of partita by S. Gubaidullina for the bayan, cello and the chamber orchestra "Seven Words".

\section{REFERENCES}

1. Башарова И. Образ флейты в сонатине Губайдуллиной. Вестник Башкирского Университета. Уфа, 2008. № 3. С. 595-598. 
2. Буданова Т. Музыка для баяна композиторов Сибири и Дальнего Востока: автореф. дисс... канд. искусств.: 17.00.02. Владивосток, 2009. $21 \mathrm{c.}$

3. Воронова О.Е. Сергей Есенин и русская духовная культура. Рязань: Узорочье, 2002. 520 с.

4. Гаккель Л. Фортепианная музыка XX века: Очерки. 2-е изд., доп. Л.: Сов. композитор, 1990. 288 с.

5. Гервер Л. Музыка и музыкальная мифология в творчестве русских поэтов (первые десятилетия XX века). М.: Индрик, 2001. $248 \mathrm{c}$.

6. Давыдова, А. В. Музыкальные образы в русской лирике начала XX века: автореф. дисс. ... канд. филол. наук: 10.01.01. Архангельск, 2006. 24 с.

7. Зайнетдинова Р.А. Становление проблемного поля концепции семиосферы Ю.М.Лотмана: историко-философский анализ: автореф. дисс. ... канд. филос. наук: 09.00.03. Екатеринбург, 2011. $24 \mathrm{c}$.

8. Иванова С. Эволюция звукового образа балалайки: автореф. дисс... канд. искусств.: 17.00.02. Магнитогорск, 2009. 26 с.

9. Карабегова Е. Символика музыкальных инструментов в немецкой литературе XIX - XX веков и «Контрабас» Патрика Зюскинда. URL: http://natapa.msk.ru/sborniki-pod-redaktsiey-nt-pahsaryan/simvolika-muzykalnyh-instrumentov-v-nemetskoyliterature-xix-xx-vekov-i-kontrabas-patrika-zyuskinda.html

10. Лазутина Т.В. Процесс символизации в музыке: дис. ... канд. филос наук: 09.00.01. Тюмень, 2003. 139 с.

11. Лосев А. История античной эстетики: Аристотель и поздняя классика. М.: Искусство, 1975. 776 с.

12. Малинковская А.В. Класс основного музыкального инструмента. Искусство фортепианного интонирования. М.: Владивосток, 2002. 381 с., нот.

13.Мастерс П. Богослужение: библейское и современное. URL: http://torrents.te.ua/to17032

14.Откровение. Глава 8. Новый завет. URL: https://bible.by/nrt/66/8/

15.Рябуха Н. Звуковий образ як феномен культури: досвід міждисциплінарного синтезу. Культура $i$ сучасність. К., 2014. Вип. 2. С. 112-120.

16. Семиотика: Антология / сост. Ю.С. Степанов. Изд. 2-е, испр. и доп. М.: Академический проспект; Екатеринбург: Деловая книга, $2001.702 \mathrm{c}$. 
17.Сухов А.В. Музыкальные образы как отражение апокалипсических мотивов в поэме с. А. Есенина «Сорокоуст». Известия высших учебных заведений. Поволжский регион. 2015. № 4 (36). C. 126-134.

18. Тимошенко А. Американский музыкальный экспериментализм первой половины XX века: представление о звуке, концепция инструмента, композиции (Г. Коуэлл, Дж. Кейдж, Л. Хэррисон): дисс. ... канд. искусств.: 17.00.02. СПб., 2004. 254 с.

19. Chernoivanenko A. Musical and instrumental foundations of modern composition techniques. National academy of managerial staff of culture and arts Herald. 2'2019. S. 444-448.

20.Copland A. Music and imagination. Cambridge: Harvard University Press, 1952. Second printing. 116 p.

\section{Information about the author:} Chernoivanenko A. D., Candidate of Art, Professor, Odessa National A. V. Nezhdanova Academy of Music 63, Novoselskogo str., Odessa, 65023, Ukraine 
Publishing house "Liha-Pres"

9 Kastelivka str., Lviv, 79012, Ukraine 44 Lubicka str., Toruń, 87-100, Poland

Printed by the publishing house "Liha-Pres"

Passed for printing: February 14, 2020. A run of 150 copies. 